SABINA MOSER TRALAMAZZA

\title{
DIVERSIDADE FÚNGICA, ANÁLISE POLIFÁSICA DO GÊNERO Fusarium E DETERMINAÇÃO DE DESOXINIVALENOL E ZEARALENONA EM GRÃOS DE TRIGO DE DIFERENTES REGIÕES DO BRASIL
}

Tese apresentada ao Programa de Pósgraduação em Microbiologia do Instituto de Ciências Biomédicas da Universidade de São Paulo, para obtenção do Título de Doutor em Ciências. 


\section{DIVERSIDADE FÚNGICA, ANÁLISE POLIFÁSICA DO GÊNERO Fusarium E DETERMINAÇÃO DE DESOXINIVALENOL E ZEARALENONA EM GRÃOS DE TRIGO DE DIFERENTES REGIÕES DO BRASIL}

Tese apresentada ao Programa de Pósgraduação em Microbiologia do Instituto de Ciências Biomédicas da Universidade de São Paulo, para obtenção do Título de Doutor em Ciências.

Área de concentração: Microbiologia

Orientador: Prof. Dr. Benedito Corrêa

Versão original 
DADOS DE CATALOGAÇĀO NA PUBLICAÇĀO (CIP)

Serviço de Biblioteca e Informação Biomédica do

Instituto de Ciências Biomédicas da Universidade de São Paulo

reprodução não autorizada pelo autor

Tralamazza, Sabina Moser.

Diversidade fúngica, análise polifásica do gênero Fusarium e determinação de desoxinivalenol e zearalenona em grãos de trigo de diferentes regiões do Brasil / Sabina Moser Tralamazza. -- São Paulo, 2015.

Orientador: Prof. Dr. Benedito Corrêa.

Tese (Doutorado) - Universidade de São Paulo. Instituto de Ciências Biomédicas. Departamento de Microbiologia. Área de concentração: Microbiologia. Linha de pesquisa: Fungos toxigênicos e micotoxinas.

Versão do título para o inglês: Fungal diversity, polyphasic analysis of the genus Fusarium and determination of deoxynivalenol and zearalenone in wheat grains from different regions of Brazil.

1. Trigo 2. Fungos 3. Fusarium 4. Tricotecenos 5. Desoxinivalenol 6. Zearalenona I. Corrêa, Prof. Dr. Benedito II. Universidade de São Paulo. Instituto de Ciências Biomédicas. Programa de Pós-Graduação em Microbiologia III. Titulo. 
UNIVERSIDADE DE SÃO PAULO

INSTITUTO DE CIÊNCIAS BIOMÉDICAS

\begin{abstract}
Candidato(a): $\quad$ Sabina Moser Tralamazza.
Título da Tese:

Diversidade fúngica, análise polifásica do gênero Fusarium e determinação de desoxinivalenol e zearalenona em grãos de trigo de diferentes regiōes do Brasil.
\end{abstract}

Orientador(a): $\quad$ Prof. Dr. Benedito Corrêa.

A Comissão Julgadora dos trabalhos de Defesa da Tese de Doutorado, em sessão pública realizada a ................., considerou
( ) Aprovado(a)
( ) Reprovado(a)

\begin{tabular}{|c|c|}
\hline Examinador(a): & $\begin{array}{l}\text { Assinatura: } \\
\text { Nome: } \\
\text { Instituição: }\end{array}$ \\
\hline Examinador(a): & 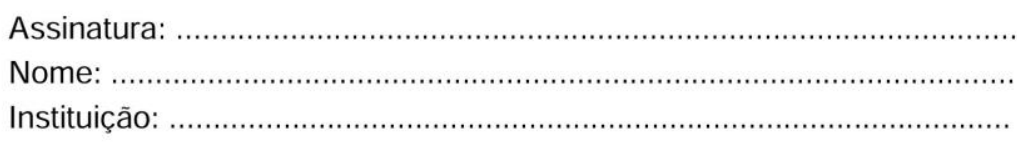 \\
\hline Examinador(a): & $\begin{array}{l}\text { Assinatura: } \\
\text { Nome: } \\
\text { Instituição: }\end{array}$ \\
\hline Examinador(a): & 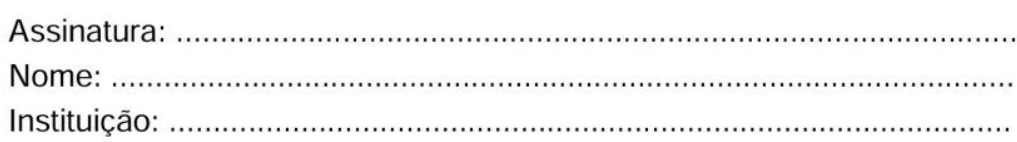 \\
\hline Presidente: & 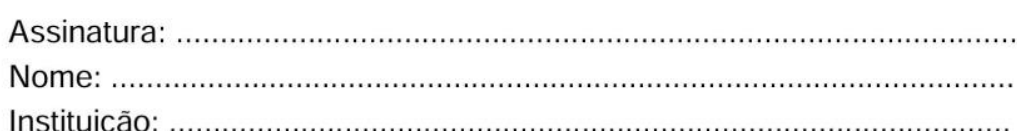 \\
\hline
\end{tabular}




UNIVERSIDADE DE SÃO PAULO
INSTITUTO DE CIÊNCIAS BIOMÉDICAS
$\begin{aligned} & \text { Cidade Universitária “Armando de Salles Oliveira” } \\ & \text { Av. Prof. Lineu Prestes, 2415 - CEP. 05508-000 São Paulo, SP - Brasil } \\ & \text { Telefone :(55) (11) 3091-7733 - telefax : (55) (11) 3091-8405 } \\ & \text { e-mail: cep@icb.usp.br }\end{aligned}$
Comissão de Ética em Pesquisa

\section{CERTIFICADO DE ISENÇÃO}

Certificamos que o Protocolo CEP-ICB N $N^{\circ} 461 / 11$ referente ao projeto intitulado: "Estudo polifásico de cepas de Fusarium spp. Produtoras de tricotecenos isoladas de milho e trigo" sob a responsabilidade de Sabina Moser Tralamazza, foi analisado na presente data pela CEUA - COMISSÃO DE ÉTICA NO USO DE ANIMAIS e pela CEPSH- COMISSÃO DE ÉTICA EM PESQUISA COM SERES HUMANOS, tendo sido deliberado que o referido projeto não utilizará animais que estejam sob a égide da lei 11.794 de 8 de outubro de 2008, nem envolverá procedimentos regulados pela Resolução CONEP n¹96 de 1996.

São Paulo, 29 de junho de 2011.
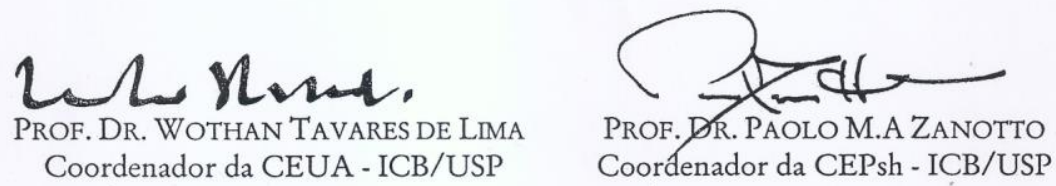


\section{AGRADECIMENTOS}

Concluir uma pós-graduação é também ter a rara oportunidade de agradecer publicamente todo amor, consideração e apoio que as pessoas me deram nesses anos todos.

\section{Assim, gostaria de agradecer imensamente:}

Ao Prof. Benedito por ter confiado em mim e em minhas ideias e por ter me dado à chance de aprender e crescer, tanto na vida profissional como pessoal.

À Prof. ${ }^{a}$ Eliana, uma pessoa que adorei conhecer e a toda sua equipe, que foram essenciais para o desenvolvimento deste trabalho;

Aos meus colegas e amigos de laboratório que me ensinaram e me ajudaram, mas principalmente me fizeram rir quando eu precisava e me entupiram de café quando eu precisava mais ainda. Segue em ordem alfabética, pois assim fica mais divertido: Arianne, Cynara, Ednei, Gabriela, Lívia, Lorena, Luciana, Patrícia, Tainah, Tatiana e Vinícius.

Ao meu estagiário Fábio por ter ajudado a desenvolver este projeto.

À minha nova prima Márcia, minha veterinária favorita Raquel e minha querida pseudo Liliana, por longas horas de conselhos e risadas.

À Renata, não só pela grande ajuda neste trabalho, mas também pela amizade;

Aos amigos que estão longe e perto, desde sempre: Angela, Anna, Bárbara e Tharcyla,.

Aos meus biólogos preferidos: Priscila, Paloma, Juliana, Eloisa e Celso.

À Fundação de Amparo e Pesquisa do Estado de São Paulo pelo apoio financeiro.

Por fim quero agradecer à minha família:

À minha mãe Irene, que sempre me apoiou, me fortaleceu e acreditou em minhas escolhas;

Ao meu pai Flávio, que nunca saiu do meu coração e meus pensamentos; 
Ao meu irmão Daniel que me ensinou a pensar e questionar o mundo a minha volta.

Ao Gregory, meu namorado e melhor amigo, pelo amor e apoio para que eu terminasse esta aventura.

À Lola, que não sabe ler (eu acho), mas que faz parte da família.

À minha grande família Moser, tios, tias, primos e primas, de que me orgulho fazer parte.

À minha segunda família: Suy, Álvaro, Thagla, Derek, Minny e Belinha, por toda ajuda nesses anos.

A Deus/ Luz/ Universo/ Anjo da Guarda, por me escutar e me tranquilizar todas as noites.

Enfim, meu muito obrigada! 
"Somewhere, something incredible is waiting to be known."

Carl Sagan 


\section{RESUMO}

TRALAMAZZA, S. M. Diversidade fúngica, análise polifásica do gênero Fusarium e determinação de desoxinivalenol e zearalenona em grãos de trigo de diferentes regiões do Brasil. 2015, 98 f. Tese (Doutorado em Microbiologia) Instituto de Ciências Biomédicas, Universidade de São Paulo, São Paulo, 2015.

A presença de micotoxinas em cereais e outros alimentos geram anualmente perdas bilionárias. Seus efeitos nocivos à saúde humana e animal tornaram várias micotoxinas um problema de saúde pública. Estudos epidemiológicos têm mostrado que a ausência de sintomas de giberela, doença causada principalmente pelo gênero Fusarium, não exclui a presença de micotoxinas, o que dificulta o controle da contaminação nos grãos. Devido à relevância da cultura de trigo na alimentação humana e animal, o presente trabalho visou utilizar o perfil polifásico, envolvendo características fenotípicas e genotípicas, na identificação de Fusarium spp. isolados de grãos de trigo como também investigar a presença das principais toxinas: desoxinivalenol e zearalenona nos grãos de trigo de três regiões produtoras de trigo (São Paulo, Paraná e Rio Grande do Sul). Para esse fim foi realizado a determinação da micobiota naturalmente encontrada em grãos de trigo recémcolhido, identificação das espécies do gênero Fusarium, detecção do perfil genotípico e quantificação do DNA dos fungos produtores de tricotecenos, análise do comportamento de expressão gênica de genes envolvidos na via de biossíntese de tricotecenos e determinação de desoxinivalenol e zearalenona nos grãos de trigo. Nossos resultados revelaram que os gêneros mais frequentes no isolamento do trigo foram Alternaria, Fusarium e Epicoccum, destacando-se também a elevada frequência de Microdochium nivale no Estado de São Paulo. Dentro do gênero Fusarium constatou-se predomínio do complexo de espécie Fusarium graminearum (CEFG), a saber: F. graminearum sensu stricto, F. meridionale, F. cortaderiae e $F$. austroamericanum. Os genótipos dos isolados foram, na sua maioria, NIV para as espécies $F$. meridionale, $F$. cortaderiae e $F$. austroamericanum, e 15-ADON para $F$. graminearum s.s. Já a determinação do genótipo nos grãos de trigo por qPCR demonstrou predomínio de $15-A D O N$ ( $100 \%$ das amostras) seguido por NIV $(80 \%)$ e $3-\operatorname{ADON}(33,3 \%)$. A quantificação de DNA dos isolados do CEFG nos grãos de trigo demostrou que o perfil 15-ADON foi responsável por $96 \%$ de todo DNA quantificado, seguido por NIV com $3.84 \%$ e $3-A D O N$, com somente $0.06 \%$, indicando que 3 $A D O N$ não é um perfil relevante e que 15-ADON, é o principal genótipo de tricoteceno nos grãos de trigo nacional. Também constatou-se diferenças na expressão gênica de acordo com a espécie filogenética analisada (TRI5 e TRI12) e do comportamento de outros genes (TRI4, TRI6 e TRI101). A toxina desoxinivalenol foi detectada em todas as 150 amostras analisadas de trigo, com mediana de 323, 466 e $783 \mu \mathrm{g} / \mathrm{kg}$ em SP, PR e RS, respectivamente. Já a determinação de zearalenona demonstrou contaminação em 100\%, $80 \%$ e $42 \%$ dos grãos dos Estados do RS, PR e SP e medianas de 843, 100 e $14 \mu \mathrm{g} / \mathrm{kg}$, respectivamente.

Palavras-chave: Trigo. Fungos. Fusarium. Tricotecenos. Desoxinivalenol. Zearalenona. 


\begin{abstract}
TRALAMAZZA, S. M. Fungal diversity, polyphasic analysis of the genus Fusarium and determination of deoxynivalenol and zearalenone in wheat grains from different regions of Brazil. 2015. 98 p. Ph. D Thesis (Microbiology) Instituto de Ciências Biomédicas, Universidade de São Paulo, São Paulo, 2015.
\end{abstract}

The presence of mycotoxins in cereals and foodstuff cause annually, billionaire losses. Their harmful effects on animals and humans became a public health problem. Epidemiologic studies showed that the absence of symptoms of Fusarium Head Blight, main disease in wheat, caused mainly by Fusarium species, do not necessarily exclude the presence of mycotoxins, which difficult contamination control of grains. Due to the wheat culture relevance in feed and foodstuff, the present work aimed to use a polyphasic approach, by phenotypic and genotypic characteristics for the identification of Fusarium strains from wheat grains as well to investigate the presence of deoxynivalenol and zearalenone on wheat grains from three wheat producers States (Parana, Rio Grande do Sul and Sao Paulo). To this end it was performed de mycobiota determination from freshly harvested wheat grains, identification of the isolates from the genus Fusarium, genotype profile and DNA quantification from trichothecene producers isolated from wheat grains, analysis of gene expression of genes involved in the trichothecene biosynthetic pathway from four producers strains and determination of deoxynivalenol and zearalenone in wheat grains. Our results showed that the most frequent genera were Alternaria, Fusarium and Epicoccum. Also, a high frequency of Microdochium nivale was found in wheat grains from Sao Paulo State. Within the Fusarium genus, Fusarium graminearum specie complex (FGSC) was dominant and four members were identified: $F$. graminearum s.s, F. meridionale, $F$. cortaderiae and $F$. austroamericanum. Genotype profiles from the FGSC isolates were mostly NIV for $F$. meridionale, $F$. cortaderiae and $F$. austroamericanum and 15-ADON for $F$. graminearum s.s. Genotype detection from qPCR revealed predominance of 15ADON (100\% of samples), followed by NIV $(80 \%)$ and $3-A D O N(33,3 \%)$. The qPCR demonstrated that 15-ADON genotype was responsible for $96 \%$ of all DNA quantified, followed by NIV with $3.84 \%$ and $3-\mathrm{ADON}$ with $0.06 \%$, indicating that $3-$ ADON genotype is not relevant profile and 15-ADON is the main trichothecene genotype from Brazilian wheat grains. The gene expression results, showed that some genes behaved according to the phylogenetic species analyzed (TRI5 and TRI12) and some according to other genes expression (TRI4, TRI6 and TRI101). The toxin deoxynivalenol was detected in all 150 samples analyzed from wheat grains, with medians of 323,466 and $783 \mu \mathrm{g} / \mathrm{kg}$ in SP, PR and RS, respectively. The zearalenone determination showed contamination on $100 \%, 80 \%$ and $42 \%$ of wheat grains from RS, PR and SP State and medians of 843, 100 and $14 \mu \mathrm{g} / \mathrm{kg}$, respectively.

Keywords: Wheat. Fungi. Fusarium. Trichothecenes. Deoxynivalenol. Zearalenone. 


\section{LISTA DE ILUSTRAÇÕES}

Quadro 1 - Limites máximos tolerados de acordo com a resolução RDCn7 estipulada pela ANVISA com aplicação a partir de 2012 e 2017 35

Figura 1 - Isolamento fúngico de grãos de trigo. .38

Quadro 2 - Iniciadores utilizados para identificação dos genótipos de tricotecenos

Quadro 3 - Iniciadores utilizados para deteç̧ão dos genótipos de tricotecenos em grãos de trigo. 43

Quadro 4 - Iniciadores utilizados para análise da expressão gênica de tricotecenos

Figura 2 - Perfil de isolamento fúngico nos grãos de trigo provenientes dos Estados do Paraná, Rio Grande do Sul e São Paulo.

Gráfico 1 - Frequência de fungos isolados de grãos de trigo provenientes dos Estados do Rio Grande do Sul, Paraná e São Paulo. .50

Figura 3 - Identificação dos isolados de Microdochium nivale com iniciadores espécie-específicos para M. nivale e M. majus. .51

Figura 4 - Morfologia da colônia de Microdochium nivale. 52

Figura 5 - Morfologia dos membros do Complexo de espécie Fusarium graminearum. .54

Gráfico 2 - Frequência dos genótipos encontrados nas diferentes espécies do Complexo de espécie F. graminearum. .56

Gráfico 3 - Frequência dos genótipos dos isolados provenientes dos Estados do Rio Grande do Sul, Paraná e São Paulo. .57

Gráfico 4 - Proporção média da concentração de DNA de fungos produtores de tricotecenos em grãos de trigo provenientes dos Estados de São Paulo, Paraná e Rio Grande do Sul. 59

Gráfico 5 - Concentração média de DNA de fungos produtores de tricotecenos em grãos de trigo provenientes dos Estados de São Paulo, Paraná e Rio Grande do Sul. .60 
Gráfico 6 - Concentração de desoxinivalenol e de DNA dos isolados fúngicos (15ADON+3-ADON) em grãos de trigo provenientes dos Estados de São Paulo,

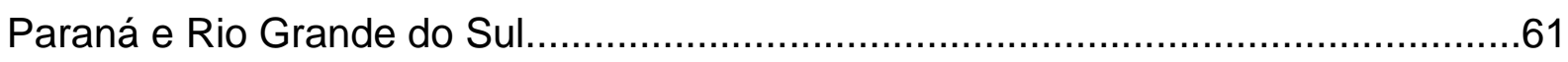

Gráfico 7 - Correlação entre produção de desoxinivalenol e concentração de DNA dos isolados (15ADON+3-ADON) em grãos de trigo.............................................62 Gráfico 8 - Expressão relativa dos genes TRI4, TRI5, TRI6, TRI12 E TRI101 dos grupos biológicos $F$. graminearum s.s, $F$. meridionale, $F$. cortaderiae e $F$.

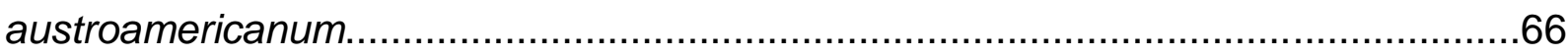

Gráfico 9 - Expressão relativa dos genes TRI6, TRI101 e TRI4 dos isolados do Complexo de espécie Fusarium graminearum. 67

Gráfico 10 - Comparação entre as médias de produção de desoxinivalenol, zearalenona e as médias da concentração de DNA dos genótipos de tricotecenos nos Estados de São Paulo, Paraná e Rio Grande do Sul.......................................72 Gráfico 11 - Porcentagem de co-ocorrência de DON e ZEA nos grãos de trigo provenientes dos Estados de São Paulo, Paraná e Rio Grande do

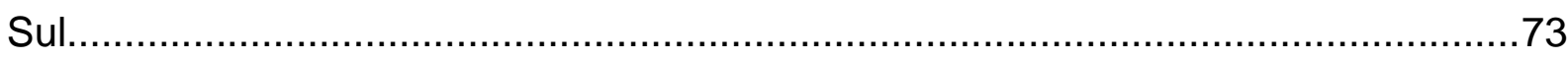




\section{LISTA DE TABELAS}

Tabela 1 - Frequência dos membros do Complexo de espécie Fusarium graminearum isolados de grãos de trigo provenientes dos Estados de São Paulo, Paraná e Rio Grande do Sul.. .55

Tabela 2 - Frequência de genótipo de tricotecenos em grãos de trigo provenientes dos Estados de São Paulo, Paraná e Rio Grande do Sul .59 Tabela 3 - Determinação de desoxinivalenol em grãos de trigo naturalmente contaminado provenientes dos Estados de São Paulo, Paraná e Rio Grande do Sul. 68

Tabela 4 - Concentrações de desoxinivalenol encontradas nos grãos de trigo provenientes dos Estados de São Paulo, Paraná e Rio Grande do Sul. 69

Tabela 5 - Determinação de zearalenona em grãos de trigo naturalmente contaminado provenientes dos Estados de São Paulo, Paraná e Rio Grande do Sul. .70

Tabela 6 - Concentrações de zearalenona encontradas nos grãos de trigo provenientes dos Estados de São Paulo, Paraná e Rio Grande do Sul. 


\section{LISTA DE ABREVIATURAS E SIGLAS}

$\mu \mathrm{g}$ - micrograma

$\mu \mathrm{l}$ - microlitro

15-ADON - 15-acetildesoxinivalenol

3-ADON - 3-acetildesoxinivalenol

$\mathrm{Aa}$ - atividade de água

AME - Alternariol monometil eter

ANVISA - Agência Nacional de Vigilância Sanitária

$\mathrm{AOH}$ - Alternariol

BDA - Batata dextrose ágar

CEFG - Complexo de espécie Fusarium graminearum

CLA - Carnation leaf agar (folha de cravo ágar)

CONAB - Companhia Nacional de Abastecimento

DOM-1 - deepoxi- desoxinivalenol

DON - desoxinivalenol

EC - European Comission (Comissão Europeia)

EF-1 $\alpha$ - Fator de elongação $1 \alpha$

EMBRAPA - Empresa Brasileira de Pesquisa Agropecuária

FAO - Food and Agriculture Organization of the United Nations (Organização de Agricultura e Alimentos das Nações Unidas)

FB1 - Fumonisina B1

FL - Fluorescência

FNE - Fungos não esporulados

ITS - Internal transcribed space (Espaçador interno transcrito)

$\mathrm{Kg}$ - kilograma

LMT- Limite Máximo Tolerado

LOD - Limite de detecção

LOQ - Limite de quantificação

MAPA - Ministério da Agricultura, Pecuária e Abastecimento

mg - miligrama

Min - minuto

$\mathrm{ml}$ - mililitro 
$\mathrm{NCBI}$ - National Center for Biotechnology Information (Centro Nacional para Informação Biotecnológica)

NIV - Nivalenol

$\mathrm{nm}$ - nanômetro

$\mathrm{pb}$ - pares de base

PCR - Polymerase chain reaction (reação em cadeia da polimerase)

PR - Estado do Paraná

qPCR - Quantitative polymerase chain reaction (Reação em cadeia da polimerase quantitativa)

RS - Estado do Rio Grande do Sul

SNA - Synthetic Nutrient Deficient Agar ( Ágar deficiente nutrient sintético)

SP - Estado de São Paulo

TA - Ácido tenuazônico

UPLC - Ultra Performance Liquid Chromatography (Cromatografia Líquida de Ultra Eficiência)

UV - Ultra Violeta

YES - Sacarose Extrato de levedura àgar

ZEA - Zearalenona 


\section{SUMÁRIO}

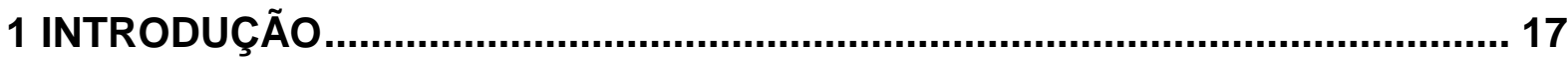

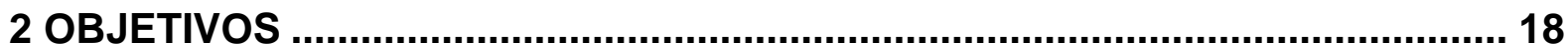

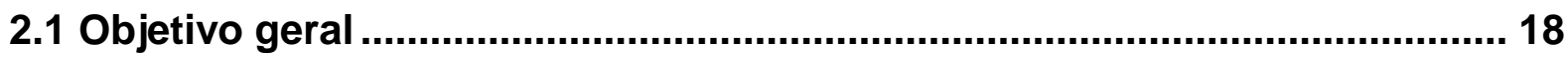

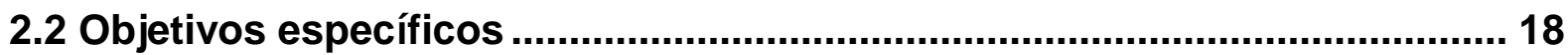

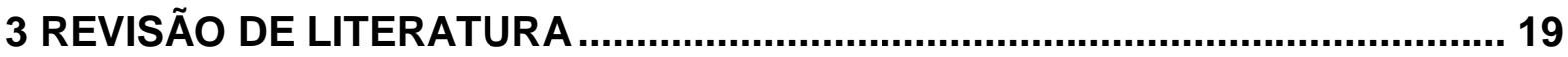

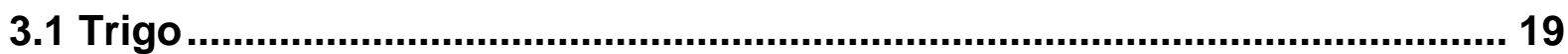

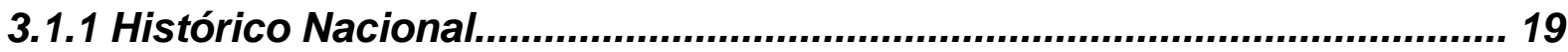

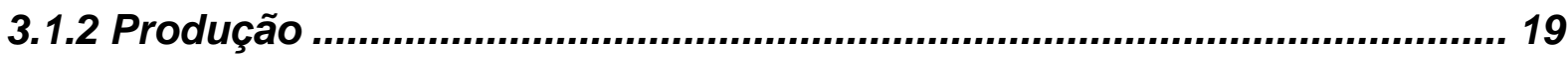

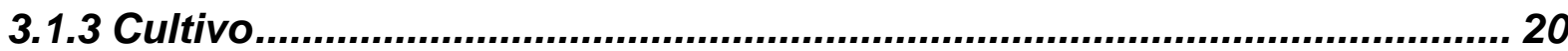

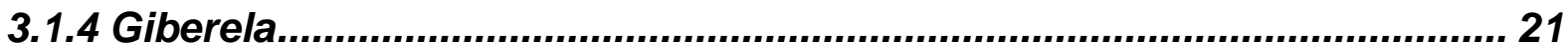

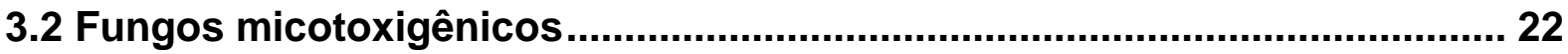

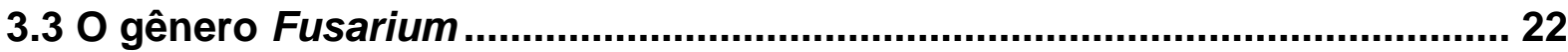

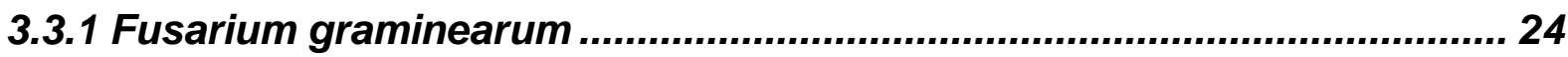

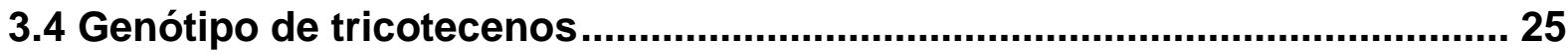

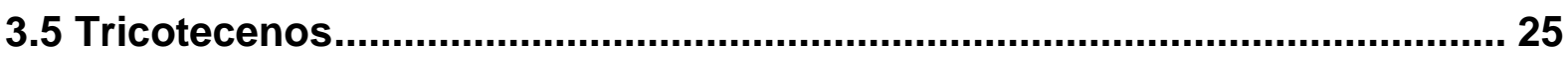

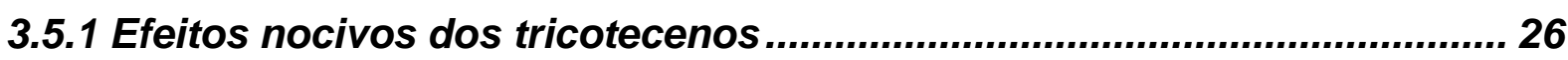

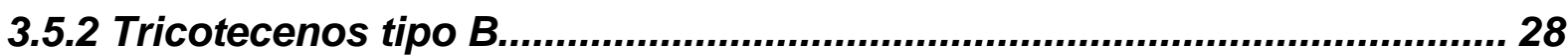

3.5.2.1 Metabolismo dos tricotecenos tipo B................................................... 28

3.5.2.2 Via de biossíntese e aspectos moleculares dos tricotecenos tipo B ............ 29

3.5.2.3 Reguladores globais de tricotecenos ..................................................... 31

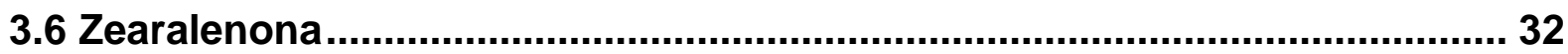

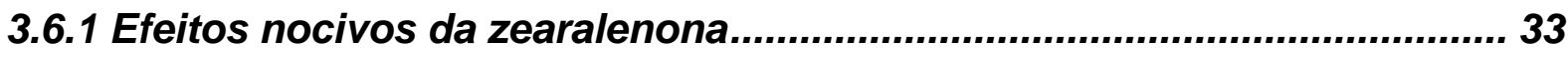

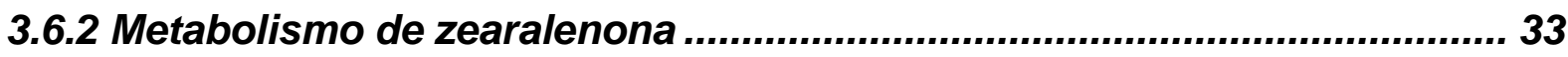

3.6.3 Biossíntese e aspectos moleculares de zearalenona.............................. 34

3.7 Legislação para desoxinivalenol e zearalenona ......................................... 34

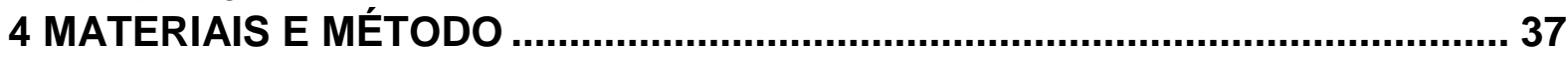

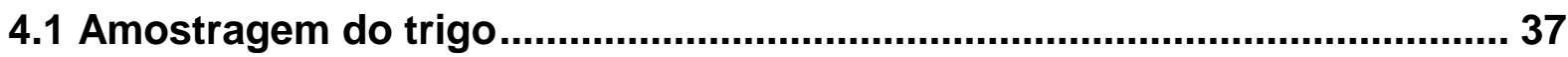

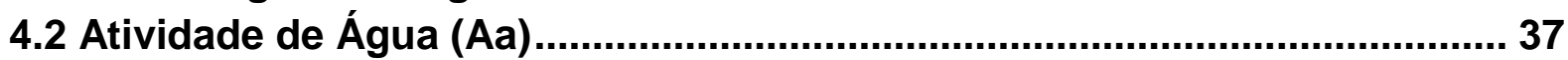

4.3 Isolamento e identificação da micobiota de amostras de grãos de trigo ... 37

4.4 Identificação dos fungos não esporulados (FNE).......................................38

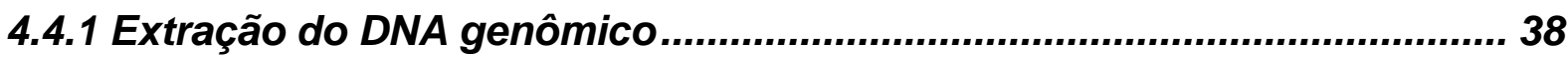

4.4.2 Identificação dos gêneros FNE pelo sequenciamento parcial da região

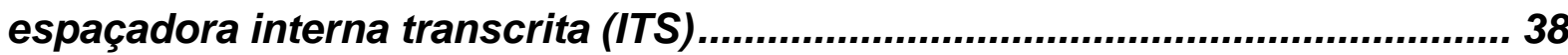

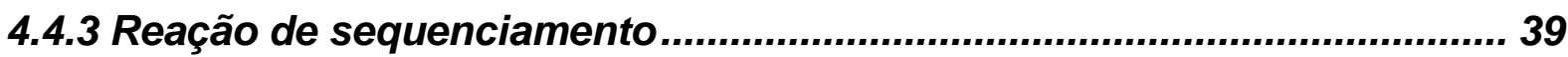

4.5 Identificação dos isolados de Microdochium spp .................................... 40

4.6 Identificação dos isolados de Fusarium spp.............................................. 40

4.7 Identificação dos genótipos de tricotecenos tipo B dos isolados do Complexo de espécie de F. graminearum ...................................................... 40

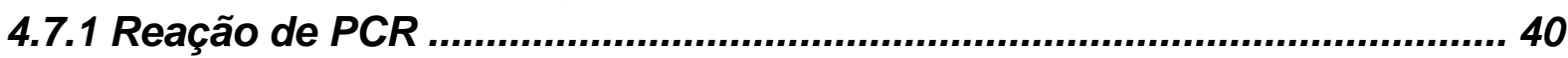

4.8 Identificação dos genótipos de tricotecenos tipo B de grãos de trigo ....... 41

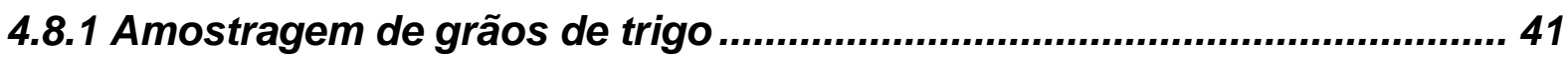

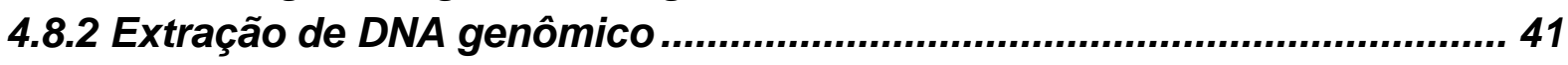

4.8.3 Reação de amplificação por PCR quantitativa (qPCR)............................ 42 
4.8.4 Validação da técnica

4.9 Expressão gênica de tricotecenos por PCR quantitativa (qPCR)............... 43

4.9.1 Cultivo e isolamento de RNA ........................................................... 43

4.9.2 Reação de amplificação dos genes TRI envolvidos na via biossintética de

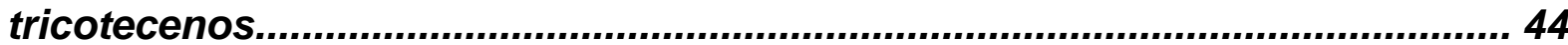

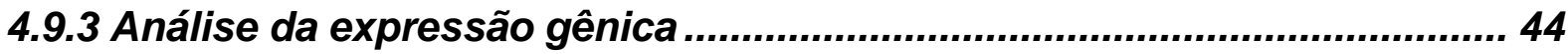

4.10 Detecção e quantificação de desoxinivalenol e zearalenona nos grãos de

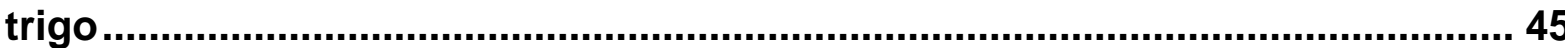

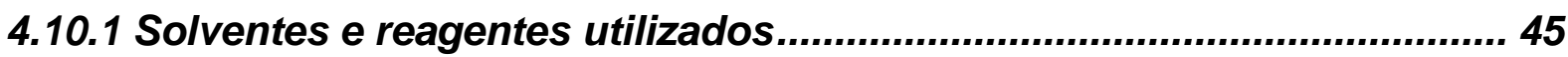

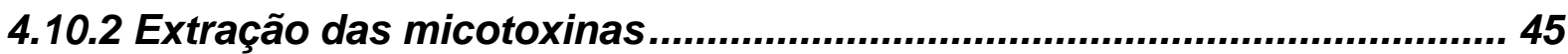

4.10.3 Instrumentação e condições cromatográficas de análise........................ 46

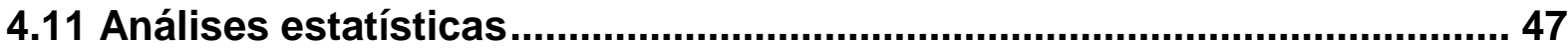

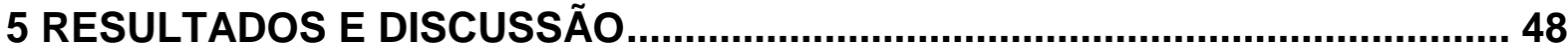

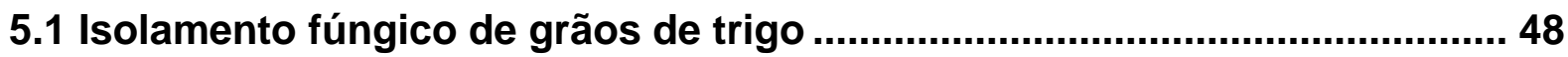

5.2 Gênero Microdochium ............................................................................ 51

5.3 Identificação dos isolados do gênero Fusarium ....................................... 52

5.4 Identificação dos genótipos de tricotecenos tipo B dos isolados do Complexo de espécie de F. graminearum ................................................... 55

5.5 Identificação dos genótipos de tricotecenos tipo $B$ em grãos de trigo ...... 58

5.6 Comparação entre a detecção dos genótipos dos isolados e a dos

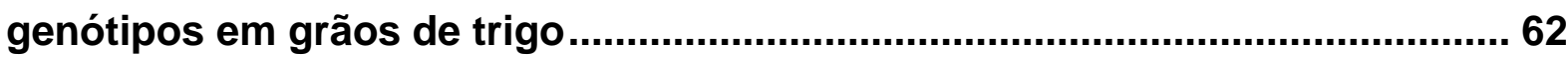

5.7 Expressão dos genes envolvidos na via biossintética de tricotecenos ..... 64

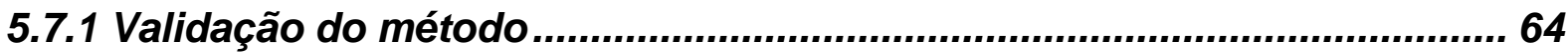

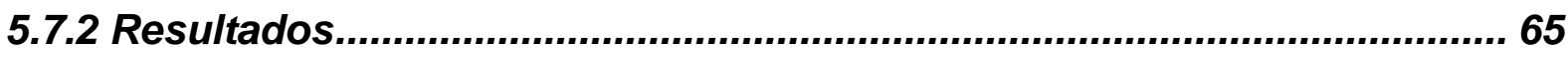

5.8 Detecção e quantificação de desoxinivalenol em grãos de trigo ................ 67

5.9 Detecção e quantificação de zearalenona em grãos de trigo ....................... 70

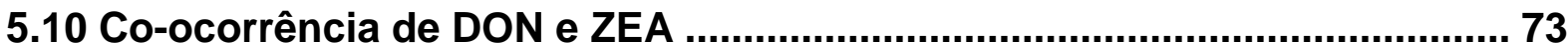

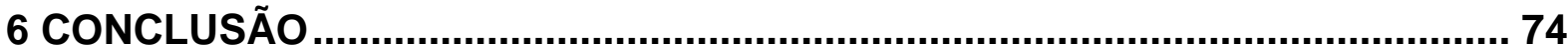

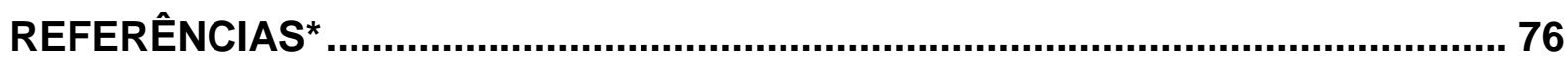

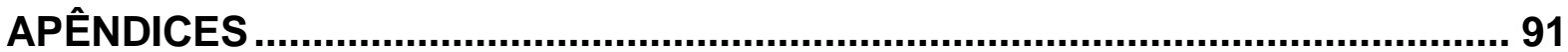

Apêndice A - Curvas padrão referentes a eficiência dos iniciadores utilizados

para análise de expressão gênica de tricotecenos.......................................... 91

Apêndice B - Curva de melting indicando a especificidade dos iniciadores utilizados na técnica de expressão gênica de tricotecenos. ............................. 93

Apêndice C - Curvas padrão para quantificação de DNA dos genótipos nos

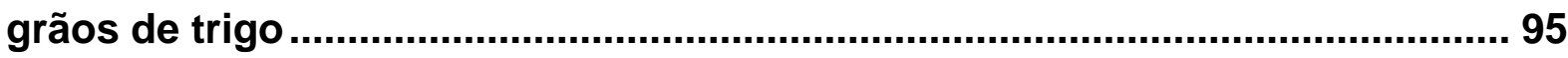

Apêndice D - Equações das curvas analíticas dos padrões de micotoxinas e

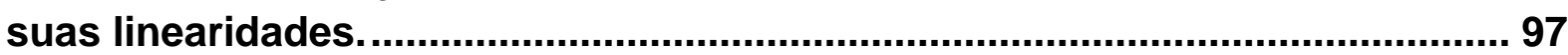
Apêndice $E$ - Cromatograma dos padrões de micotoxinas no detector A (ZEA) e B (DON). 


\section{INTRODUÇÃO}

O Brasil não é um grande produtor de trigo, o alto valor de produção e falta de incentivo do governo não permitiu essa cultura desenvolver todo seu potencial no país. Porém, o interesse tem aumentado, e a perspectiva é de um aumento de área plantada para a próxima safra (COMPANHIA NACIONAL DE ABASTECIMENTO CONAB, 2015). Dessa forma, existe a necessidade de desenvolver um produto de boa qualidade e principalmente seguro para consumo. $O$ complexo de espécie Fusarium graminearum (CEFG) são os principais agentes etiológicos de giberela, doença que torna as espigas de trigo rosadas, gerando grãos ardidos com aspecto enrugado, chocho e não comercializáveis (DILL-MACKY; JONES, 2000; GARCIA JÚNIOR, et al., 2008). Além da perda de produção, esses mesmos fungos podem produzir metabólitos tóxicos quando estão se multiplicando nos alimentos. Estes metabólitos recebem a denominação genérica de "micotoxinas" e correspondem a produtos metabólitos secundários que, quando ingeridos com os alimentos, causam alterações biológicas prejudiciais tanto no homem quanto outros animais (CAST, 2003). De acordo com a Food and Agriculture Organization of the United Nations (FAO), as perdas mundiais de alimentos contaminados por micotoxinas estão em torno de 1000 milhões de toneladas por ano (FAO, 1997). No trigo, as micotoxinas predominantes são os tricotecenos, principalmente desoxinivalenol. Os tricotecenos são sesquiterpenos que podem causar vômito, perda de peso, desnutrição, efeitos neurotóxicos e teratogênicos (MARESCA, 2013). Outra micotoxina presente no trigo é a zearalenona que possui forte efeito estrogênico devido sua alta afinidade com os receptores de estrogênio de animais e humanos. O metabólito é responsável por causar sérios danos nos órgãos reprodutivos, como carcinomas, hiperplasia do útero, diminuição de fertilidade, modificação da próstata, entre muitos outros (ZINEDINE, et al., 2007). Em virtude da escassez de trabalhos sobre a diversidade fúngica e a presença de toxinas no trigo brasileiro, ainda não foi possível definir o perfil micotoxigênico dos grãos produzidos no Brasil.

Nosso trabalho teve como objetivo contribuir para uma melhor compreensão do perfil fúngico e do perfil de toxinas produzidas no trigo brasileiro, agregando assim mais informações para que diretrizes e regulamentações estejam de acordo com a realidade do nosso país. 


\section{OBJETIVOS}

\subsection{Objetivo geral}

- Identificar as espécies do complexo de espécie Fusarium isoladas de grãos de trigo em três regiões produtoras do Estado do Rio Grande do Sul, Paraná e São Paulo; utilizando estudo polifásico (características fenotípicas e genotípicas);

\subsection{Objetivos específicos}

- Caracterizar a micobiota dos grãos de trigo recém-colhidos provenientes de regiões produtoras do Estado do Rio Grande do Sul, Paraná e São Paulo;

- Analisar os aspectos morfológicos dos isolados pertencentes ao complexo de espécie F. graminearum;

- Identificar as espécies de Fusarium, a partir do sequenciamento do gene fator de elongação alfa (TEF-1 $\alpha$ );

- Caracterizar, empregando PCR, os isolados do complexo de espécie $F$. graminearum de acordo com seus genótipos (NIV; DON; 3ADON; 15ADON);

- Determinar, nas amostras de grãos de trigo, o perfil genotípico e quantificar o DNA dos genótipos através do PCR quantitativa;

- Avaliar, utilizando a técnica de PCR quantitativa, o perfil de expressão dos genes $T R I$ a partir das espécies $F$. graminearum sensu stricto, $F$. meridionale, F. cortaderiae e F. austroamericanum;

- Detectar e quantificar a presença de desoxinivalenol e zearalenona nos grãos de trigo provenientes das regiões produtoras do Estado do Rio Grande do Sul, Paraná e São Paulo; 


\section{REVISÃO DE LITERATURA}

\subsection{Trigo}

\subsubsection{Histórico Nacional}

O trigo (Triticum aestivum) foi introduzido no Brasil em 1534, na capitania São Vicente (atual Estado de São Paulo). No Rio Grande do Sul o trigo foi levado em 1737 onde passou a ser cultivado de maneira significativa com enfoque tanto no mercado interno como externo. Porém, devido à localização estratégica do Estado, em 1793 a coroa Portuguesa proibiu a exportação do trigo gaúcho, perdendo-se um mercado importante. Historiadores acreditam que somado a esse fato, o interesse na pecuária, conflitos estabelecidos no Estado que perduraram até 1870 e o surgimento de pragas foram fatores decisivos para o desaparecimento da cultura de trigo em 1823. A cultura ressurgiu por volta de $1875 \mathrm{com}$ a vinda dos primeiros imigrantes italianos. Incentivos e novas regulamentações permitiram a cultura se fortalecer novamente (JACOBSEN, 2003).

\subsubsection{Produção}

O trigo é o terceiro cereal mais cultivado no mundo, após o milho e o arroz (FAO, 2015). Porém, hoje o Brasil não é um grande produtor de trigo. Com uma produção nacional aproximada de cinco milhões de toneladas e consumo interno de 11 milhões, mais da metade do trigo consumido no país precisa ser importado (CONAB, 2015). Hoje a maioria do trigo tem origem na Argentina, Estados Unidos e Uruguai. Essa discrepância ocorre devido a inúmeros fatores, como alto valor de produção, falta de incentivo do governo, acordos de importação que não protegem o mercado interno, além da necessidade de clima e solo adequados.

Felizmente, nos últimos anos devido ao avanço genético e manejo, aumentou o interesse por parte dos agricultores em investir na cultura do trigo, o que gerou um aumento significativo tanto na área de cultivo como de produção (CONAB, 2015). Diante da mudança de mercado, os estudos voltados a qualidade do grão nacional são essenciais. 
Devido à preferência por temperaturas amenas, os maiores produtores de trigo no Brasil ficam na região Sul, nos Estados do Rio Grande do Sul e Paraná. Sendo o RS responsável por quase $90 \%$ da produção. Produções em menor escala também se encontram em São Paulo, Minas Gerais e Santa Catarina (CONAB, 2015).

\subsubsection{Cultivo}

O período de semeadura, cultivar, adubação do solo como também o manejo da cultura diferem de acordo com o local que é realizado o cultivo. No RS, principal produtor de trigo, a semeadura se dá entre maio e julho, dependendo da região. $\mathrm{O}$ ciclo de desenvolvimento da cultura pode ser dividido em três fases: vegetativa, reprodutiva e de enchimento dos grãos.

A fase vegetativa envolve a germinação das sementes até o desenvolvimento das primeiras estruturas foliares (estádio duplo-anel). A fase reprodutiva engloba o período que vai do estádio duplo-anel até antese (floração). Nesse período ocorre a diferenciação das estruturas florais e o número de flores férteis (virtualmente 0 número de grãos). A última fase é definida pelo enchimento dos grãos e vai da fase da antese até a maturação, definido pela massa final de cada grão (EMPRESA BRASILEIRA DE PESQUISA AGROPECUÁRIA - EMBRAPA, 2002).

$O$ período da semeadura a colheita leve em torno de 120 dias. Porém tem-se investido em cultivares de ciclo precoce (em torno de 110) para evitar intempéries como também antecipar a safra de verão (SCHEEREN et al., 2007).

No processo de colheita o ideal é coletar os grãos com umidade em torno de $13 \%$. Entretanto para se evitar mau tempo lavouras podem ser colhidas antecipadamente. Nesses casos, ocorre o processo de secagem para reduzir a umidade. Na última etapa, a de armazenamento, vários cuidados são tomados para evitar a perda de qualidade dos grãos ou deterioração: o teor de umidade não deve ultrapassar os $13 \%$, tanto os silos como equipamentos devem ser higienizados e 0 local de armazenamento bem areado (EMBRAPA, 2002).

Desde 2010 novas regras normativas foram realizadas para determinação da qualidade do trigo. De maneira geral, o grão é avaliado tanto por sua aparência (coloração, defeitos, não germinados), presença de doença (giberela, ferrugem, 
brunose) e limpeza. Como também por suas características físico-químicas como estabilidade (tempo que uma massa mantém estável suas características viscoelásticas), força do glúten (trabalho mecânico necessário para expandir a massa até sua ruptura) e peso hectolitro (a massa de 100 litros de trigo expressa em quilograma) (MINISTÉRIO DA AGRICULTURA, PECUÁRIA E ABASTECIMENTO - MAPA, 2010).

\subsubsection{Giberela}

As plantações de grãos podem ser acometidas por várias doenças e muitas são ocasionadas por fungos, sobretudo quando não é realizado um manejo adequado. Dentre os fatores que afetam a transmissão de patógenos a partir da semente e que podem afetar o estabelecimento do patógeno em uma cultura, destacam-se: a espécie cultivada, condições do solo, temperatura, vento, chuva, inóculo, práticas culturais, microflora do solo e da semente (BARBA et al., 2002).

A giberela é uma doença de infecção floral causada principalmente pelos membros do Complexo de espécie Fusarium graminearum, e em menor frequência por espécies como F. culmorum e F. avenaceum. Ela afeta diversos cereais em todo mundo (CHAMPEIL; DORÈ; FOURBET, 2004; PARRY; JENKINSON; McLEOD, 1995) e foi descrita pela primeira vez no Reino Unido no fim do século 19 (SMITH, 1884 apud CHAMPEIL; DORĖ; FOURBET, 2004).

A via inicial de infecção é no período de extrusão das anteras (floração) da planta (LACEY; BATEMAN; MIROCHA, 1999; STRANGE; SMITH, 1971). O fungo sobrevive entre as estações de cultivo como saprófito na superfície do solo em resíduos de culturas anteriores. Sob condições ótimas de umidade (elevada) e temperatura (20-30 $\left.{ }^{\circ} \mathrm{C}\right)$, produz peritécios que liberam seus esporos sexuais (BAI, 1994). Esses esporos juntamente com esporos assexuais (macroconídeos) podem ser carregados a longas distâncias através do vento e da chuva. A partir da infecção na etapa de floração, o fungo se propaga para o resto do tecido vegetal. Os danos causados pela doença são qualitativos como quantitativos. A doença torna as espigas de trigo rosadas, acarretando em grãos ardidos com aspecto enrugado e chocho (DILL-MACKY; JONES, 2000; GARCIA JÚNIOR, et al., 2008; ROSSI et al., 2001). Ela também reduz a qualidade nutritiva e tecnológica dos grãos (teor de 
proteínas, valores nutricionais e vigor de sementes (HORVAT et al., 2014; SIUDA et al., 2010).

$\mathrm{Na}$ Argentina, nosso maior exportador de trigo, surtos da doença foram relatados em 1978, 1985, 1993 e 2001, com perdas variando entre $20 \%$ a $50 \%$ (BAINOTTI et al., 2013). Estudos no Brasil mostram que a presença de giberela nas lavouras do RS é persistente e sua incidência vem aumentando ao longo dos anos (CASA et al., 2004; EMBRAPA, 2014; PANISSON; REIS; BOLLER, 2003)

\subsection{Fungos micotoxigênicos}

Além causar giberela, as espécies de Fusarium também são potencialmente produtoras de micotoxinas, principalmente zearalenona e tricotecenos. Metabólitos que causam sério prejuízo econômico no setor de grãos e cereais. Estes metabólitos recebem a denominação genérica de "micotoxinas" e correspondem a produtos metabólitos secundários que, quando ingeridos com os alimentos, causam alterações biológicas prejudiciais tanto no homem quanto outros animais (CAST, 2003).

O alto potencial toxigênico e fitopatológico revela a necessidade de estudar profundamente a taxonomia do gênero Fusarium. Entretanto, a identificação e classificação do gênero Fusarium foi sempre complexa e controversa, diferindo entre si principalmente pelas metodologias adotadas. (NELSON; DIGNANI; ANAISSIE, 1994).

\subsection{O gênero Fusarium}

O fungo Fusarium foi primeiramente descrito por Link em 1809 e na época denominado Fusisporium. Com mais de 1000 indivíduos descritos, o gênero foi divido pela primeira vez por Wollenweber e Reinking (1935). Os autores separaram o grupo em 16 seções que incluíam 65 espécies, 55 variedades e 22 formas, utilizando critérios morfológicos como tamanho e forma de macroconídeos, presença de clamidósporos como também crescimento em diferentes meios. Entretanto, ao longo dos anos diversas divisões foram criadas para o gênero 
(NELSON, 1991). Em 1940 Snyder e Hansem diminuíram severamente o número de espécies para somente nove. Décadas depois, Niremberg em 1982, categorizou o gênero em aproximadamente 90 espécies e Nelson um ano depois, destacou 30 espécies oficiais e classificou outras 16 como prováveis espécies. (BROWN; PROCTOR, 2013).

Contudo, com o tempo diferentes definições de espécies começaram a surgir. O uso do cruzamento sexual entre diferentes espécies fúngicas (mating type) definiu um novo conceito: o conceito biológico de espécie. Este conceito é definido por: indivíduos capazes de cruzar entre si, combinar informação genética e passar para progênie. Essa técnica permitiu a identificação de novas espécies antes crípticas como, por exemplo, F. thapsinum (KLITTICH et al., 1997).

$\mathrm{O}$ uso de marcadores bioquímicos tem sido outra importante ferramenta para a identificação na micologia. Um perfil de metabólitos secundários pode incluir toxinas, antibióticos e outros componentes. Eles são produzidos por um número limitados de espécies dentro de um gênero, ordem ou ainda filo e possuem um alto poder de diferenciação (FRISVAD; ANDERSEN; THRANE, 2008). Zain (2010) definiu o perfil bioquímico de diferentes isolados de Fusarium, analisando ácidos graxos, aminoácidos e metabólitos secundários e observou que o último obteve maior diversidade e possuía potencial como uma ferramenta para identificação do gênero.

Atualmente para descrição de novas espécies do gênero Fusarium ou para solução de antigos problemas taxonômicos, o conceito de espécie filogenética tem sido o mais empregado. As técnicas moleculares permitiram identificar espécies através de suas sequências parciais de DNA de um ou mais genes e relaciona-las evolutivamente. As descrições mais recentes de novas espécies como nos casos dos complexos de espécies de F. graminearum, G. fujikuroi e $F$. solani foram definidas, sobretudo através de suas filogenias (BROWN; PROCTOR, 2013).

Com o advento da filogenia, as informações sobre o grupo Fusarium se tornaram mais robustas, porém intricadas. Os tipos e número de genes estudados, como a qualidade da análise, podem afetar severamente o resultado final.

Assim, diante das limitações de cada conceito, a abordagem polifásica, agregando informações filogenéticas, biológicas, morfológicas e bioquímicas, tem sido empregada para resolver questões taxonômicas de maneira mais robusta no gênero Fusarium (BROWN; PROCTOR, 2013). 


\subsubsection{Fusarium graminearum}

F. graminearum (Schawabe) Petch, (1936) (forma teleomórfica Giberella zeae Schwein) por muitos anos foi considerado uma única espécie. Inicialmente a espécie foi dividida em dois grupos: grupo I é caracterizado por isolados heterotálicos (requer dois organismos com mating type diferentes para reprodução) e quando cultivados em meio CLA não desenvolvem peritécio e grupo II é definido por isolados homotálicos (organismo apresenta ambos mating types necessários para reprodução) e com alta formação de peritécios em meio CLA (FRANCIS; BURGESS, 1977). Em 1999, a espécie foi redefinida. A classificação por grupos foi extinta através do estudo das estruturas morfológicas, como também análise do gene $\beta$-tubulina e o então grupo II foi mantido como $F$. graminearum e o grupo I foi redefinido como a nova espécie F. pseudograminearum (AOKI; O’DONNEL, 1999).

Uma investigação em 2000, por análise filogenética de seis genes nucleares determinou que a espécie pandêmica $F$. graminearum na realidade era formada por um clado monofilético que continha sete linhagens estruturadas geograficamente. Contudo, somente em 2004 após a análise de 11 genes nucleares e características morfológicas, o complexo de espécie Fusarium graminearum (CEFG) foi definido e dividido em 9 espécies filogenéticas (O’DONNEL et al., 2004). Acredita-se que eventos de separação geográfica levaram às diferenças gênicas entre as espécies como também ao isolamento reprodutivo entre a maioria dos membros.

CEFG são morfologicamente semelhantes entre si, sendo que a maioria não pode ser identificada por suas características fenotípicas. Todos os membros estudados são potenciais produtores de ao menos uma forma de tricoteceno tipo $B$ (O’DONNEL et al., 2004). Evidências recentes mostraram a existência de isolados da espécie F. graminearum s.s (linhagem 7) que não são produtores de tricotecenos tipo $B$ no entanto são produtores de duas recém descobertas - toxinas NX-2 e NX-3 - do grupo de tricotecenos tipo A (VARGA et al., 2014). Entretanto, essa descoberta é nova e precisa ser mais bem esclarecida. Após a formação do clado, novas espécies foram incluídas e até o momento 16 espécies fazem parte do complexo. 


\subsection{Genótipo de tricotecenos}

A determinação do potencial toxigênico do fungo pela sua sequência gênica é denominada genótipo. Na literatura, também é possível encontrar o termo quimiotipo (JENNINGS et al., 2004; LEE et al., 2001; STEPIEN et al., 2008) porém, quimiotipo deve ser utilizado somente quando for realizada a determinação química das toxinas (DESJARDINS, 2006).

Os isolados produtores de tricotecenos tipo B normalmente apresentam um dos três perfis de genótipo: NIV - nivalenol e seus derivados acetilados; 3-ADON desoxinivalenol e o derivado 3-acetildesoxinivalenol; 15-ADON - desoxinivalenol e o derivado 15-acetildesoxinivalenol (WARD et al., 2002). Com o sequenciamento e compreensão das funções dos genes TRI envolvidos na via biossintética de tricotecenos, foram desenvolvidos iniciadores específicos para determinação do genótipo. Iniciadores baseados nas sequências dos genes TRI3 e TRI12 (WARD et al., 2002) foram desenvolvidos para diferenciar três genótipos toxigênicos (3-ADON, 15-ADON e NIV) e os genes TRI7 e TRI13 (CHANDLER et al., 2003) para distinguir os genótipos DON e NIV.

A capacidade de predição utilizando o perfil genotípico é normalmente consistente com o real potencial toxigênico dos isolados (QUARTA et al., 2006; REYNOSO et al., 2011; WARD et al., 2002) contudo, há relatos onde foram encontradas algumas inconsistências (ALVAREZ et al., 2009; FERNANDEZ et al., 2008).

O uso da técnica de genótipo permite definir a distribuição geográfica do perfil toxigênico e prever o impacto desses patógenos na segurança alimentar, de maneira mais acessível que a determinação do conteúdo toxigênico por análises químicas.

\subsection{Tricotecenos}

Os tricotecenos são caracterizados pela presença do esqueleto tetracíclico 12,13-epoxitricoteno (GUTLEB; MORRISON; MURK; 2002) e podem ser divididos em quatro tipos (A-D) de acordo com seus grupos funcionais característicos. Tipo $A$ possui um grupo isovaleril ao C-8 e membros desse grupo incluem toxina HT-2, 
toxina T-2 e diacetoxiscirpenol (DAS). Tipo B possui no $\mathrm{C}-8$ um grupo carbonil e incluem desoxinivalenol (DON), seus derivados (3-ADON e 15-ADON), nivalenol (NIV) e seu derivado (4-ANIV). Tipo $C$ e $D$ são menos frequentes e suas diferenças ocorrem devido a presença de um segundo grupo epoxi no C- 7, 8 ou C-9,10 e a presença de um anel macrocíclico entre C-4,5 e C-5, respectivamente (GUTLEB; MORRISON; MURK, 2002; UENO, 1983). Em geral, os tricotecenos do tipo D e C são os mais tóxicos, seguido pelo tipo A e B (UENO, 1984). Contudo, a elevada frequência de tipo $B$ encontrados em cereais ocasionou um maior impulso de estudos nesta área (DESJARDINS, 2009). Em 2013, membros da Autoridade de Segurança Europeia realizaram uma avaliação toxicológica com mais de 26 mil cereais e produtos derivados de cereais e constataram a presença de DON em $44,6 \%, 43,5 \%$ e $75,2 \%$ em grãos pré-processados, alimentos e rações animais, respectivamente (EFSA, 2013).

\subsubsection{Efeitos nocivos dos tricotecenos}

O número de trabalhos documentando os efeitos prejudiciais devido a ingestão de tricotecenos vem aumentando. Tricotecenos de maneira geral inibem a síntese de proteínas in vivo e in vitro (AZCONA et al., 1995; UENO, 1983). Estudos já mostraram que a ingestão de DON e NIV pode induzir a vômitos, deficiências nutricionais, perda de peso e anorexia em animais (PESTKA; AMOLINSKI, 2005; SMITH; HEMILLAN; CASTILLO, 1997; TAKAHASHI et al., 2008; UENO, 1983), também ambos possuem efeitos imunotóxicos. Pesquisadores mostram que a dose, frequência e tempo de exposição podem estimular ou suprimir o sistema imune do organismo. Alterações nos anticorpos lgA lgG e IgM como também interleucinas e células MPKs já foram relatadas (GOUZE et al., 2007; PESTKA, 2004). Outro efeito bem descrito são as alterações no sistema reprodutivo. Pesquisadores apontam que a ingestão de DON e NIV em camundongos grávidas causa diminuição do tamanho e peso do útero, redução fetal e aumento no número de mortes fetais (COLLINS et al., 2006; ITO, 1986). A toxina T-2 também demonstrou causar efeitos citotóxicos como apoptose celular (KONIGS et al., 2009), levar a alterações do sistema reprodutivo de camundongos (YANG et al., 2010) e deficiência nutricionais (FRANKIC; SALOBIR; REZA, 2008). 
Em humanos a avaliação dos efeitos é principalmente evidenciada por estudos in vitro. Trabalhos utilizando linhagens celulares humanas como células leucêmicas (HL60) mostram que DON e NIV atuam na diminuição da proliferação celular, sendo NIV mais potente que DON. Resultados similares também foram registrados com outra linhagem semelhante à MOLT-4 (NAGASHIMA et al., 2006, 2012). Outro estudo estudos utilizando linhagem humana intestinal Caco-2, indicam que DON também apresenta potencial genotóxico (BONY et al.,2006). Aumento na permeabilidade da barreira paracelular epitelial também foi documentado como um dos efeitos de DON, 3-ADON e 15-ADON na mesma linhagem celular (KADOTA et al., 2013).

Mesmo diante de tantos estudos demonstrando os diversos efeitos nocivos que os tricotecenos podem causar em animais e humanos, identificar os casos de contaminação dessas toxinas continua sendo um desafio. Peraica et al. (1999), relatam prováveis eventos de micotoxicoses em humanos envolvendo tricotecenos. A primeira grande manifestação reconhecida foi de aleukia (ausência ou extrema redução de glóbulos brancos na circulação sanguínea), ocorrida em 1932 na União Soviética, onde houve uma taxa de mortalidade de cerca de $60 \%$. Um caso mais recente ocorreu na Índia em 1987, onde aproximadamente 100 pessoas foram afetadas por irritação na garganta, dor abdominal e diarreia, e acredita-se que as toxinas NIV, T-2 e DON foram responsáveis pelo surto. Casos isolados também já foram relatados. Etzel et al. (1998) associaram um surto de intensa hemorragia pulmonária aguda em crianças com a inalação de Stachybotrys atra, espécie também produtora de tricotecenos. Os pesquisadores isolaram uma quantidade significativa do fungo nas residências dos pacientes quando comparado ao grupo controle, porém a responsabilidade não foi oficialmente confirmada.

Comprovar surtos decorrentes da ingestão de alimentos contaminados por micotoxinas é uma tarefa desafiadora, principalmente em humanos onde os casos são normalmente de intoxicações agudas com sintomas similares a várias patologias. A falta de informação e investigação acaba levando a diagnósticos equivocados ou a carência de registros. 


\subsubsection{Tricotecenos tipo B}

\subsubsection{Metabolismo dos tricotecenos tipo $B$}

Uma extensa revisão por Maresca (2013) agrega de maneira clara o que possivelmente ocorre no processo de ingestão de desoxinivalenol. Após a ingestão oral de DON ou de seus derivados (3-ADON, 15ADON), a primeira fase de intoxicação ocorre na passagem da parede intestinal. Porém a eficiência de absorção e metabolização de DON varia muito de acordo com a espécie animal. A microbiota intestinal que vive em simbiose com o hospedeiro é fortemente responsável por essa variação (BARNETT et al., 2012; CHOW et al., 2010).

Em aves ou animais poligástricos (mais de uma cavidade digestiva) como os ruminantes, elevadas populações bacterianas ocorrem tanto antes do intestino delgado (ex: rúmen) como depois (ex: cólon) (FREY, et al., 2010). A presença dessa população no rúmen reduz extensivamente a quantidade de DON que irá atingir o intestino delgado para absorção, levando esses animais a serem quase insensíveis à intoxicação oral por DON. Isso ocorre porque parte da população bacteriana desses animais é capaz de converter DON em DOM-1, metabólito não tóxico devido à retirada do grupo epóxi responsável pela principal toxicidade do metabólito.

Já animais monogástricos (uma cavidade digestiva) como humanos, porcos e roedores, o maior conteúdo bacteriano se encontra no cólon, após o intestino delgado (WALTER; LEY, 2001). Assim, elevadas quantidades de DON conseguem cruzar o epitélio intestinal e alcançar o compartimento sanguíneo. Estudos mostram que porcos que ingeriram DON de forma aguda ou crônica, tiveram 54\% e 89\% da toxina absorvida, respectivamente (GOYARTS; DÄNICKE et al., 2006). Ao contrário de vacas que somente $16 \%$ da toxina ingerida atingem o intestino delgado e apenas $1 \%$ é encontrado no sangue (PRELUSKY et al., 1984). Após a intoxicação oral em porcos, DON é detectado no plasma em até 30 minutos e atinge sua maior concentração após 2-3 horas de exposição, sugerindo uma rápida absorção através do intestino delgado, principalmente no jejuno (DANICKE; VALENTA; DOLL, 2004; GOYARTS; DÄNICKE et al., 2006)

Diferentemente de aves e ruminantes, a transformação de DON em DOM-1 em animais monogástricos ocorre essencialmente pela população bacteriana no cólon. Por isso somente uma pequena porcentagem de DON ingerido é encontrado 
em fezes desses animais, pois a maior parte já foi absorvida no intestino delgado. A eliminação de DON e metabólitos derivados ocorrem principalmente pela urina em forma de DON, glucoronado-DON (D3GA e D15GA), glucoronado-DOM-1 e DOM-1 (ERIKSSEN et al., 2002; ERIKSSEN; PETTERSSON; LINDBERG, 2003). As formas glucoronadas são uma maneira de o próprio organismo diminuir a toxicidade do metabólito. Essa estratégia ocorre tanto em animais (D3GA e D15GA) como em plantas (D3G). As enzimas glicoronil transferases inserem um ácido glicorônico no substrato (DON), elevando a polaridade do metabólito e dificultando o seu transporte pela membrana celular. Também a adição do ácido confere ao metabólito um aumento em sua solubilidade e consequente aumento na velocidade de sua eliminação pela urina e fezes (WU et al., 2007).

Além da barreira intestinal, estudos mostram que DON também é capaz de ultrapassar a barreira sanguínea e chegar às células cerebrais. A barreira é formada por deposição de células endoteliais e gliais que permite uma seleção na passagem de moléculas do plasma para o fluido cerebrospinal (FCS) (NICO; RIBATTI, 2012). Estudos in vivo apontam que DON consegue ultrapassar a barreira de maneira rápida, sendo detectado até 60 minutos após exposição de acordo com a espécie (PRELUSKY; HARTIN; TRENHOLM, 1990). Em porcos, 25-30\% do DON plasmático é encontrado no FCS. Em ovelhas esse valor cai para 5\% (PESTKA; ISLAM; AMUZIE, 2008). O mecanismo de absorção ainda não está esclarecido, porém DON é detectado unicamente em sua forma original, indicando que seus derivados são incapazes de ultrapassar a barreira (PRELUSKY; HARTIN; TRENHOLM, 1990).

\subsubsection{Via de biossíntese e aspectos moleculares dos tricotecenos tipo $B$}

Os genes regulatórios e de biossíntese de tricotecenos tipo $B$ foram mapeados em 4 diferentes loci dentro de F. graminearum. A via biossintética de tricotecenos das espécies de Fusarium envolve uma série de ciclizações, acetilações e oxigenações e até o momento foram identificados 16 genes com funções definidas envolvidos na via, sendo 13 indispensáveis para garantir a produção de tricotecenos. (DESJARDINS; PROCTOR, 2007).

O gene TRI5 foi o primeiro gene a ser descoberto na via de biossíntese de tricotecenos. Ele codifica a enzima tricodieno sintetase, que forma tricodieno, 
precursor de todos os tricotecenos. Por ser o primeiro gene identificado e estar inserido no cerne, TRI5 também é o nome do maior cluster da via, compreendendo 12 genes (DESJARDINS, 2006). Em outro locus estão os genes TRI1 e TRI16 que codificam para enzimas que catalisam a oxigenação de C-8 e O- acetiltranferase, respectivamente. Em dois outros loci estão TRI101 que codifica uma C-3 Oacetiltransferase e TRI15 que forma um fator de transcrição dedo de zinco e é possivelmente um regulador da via (ALEXANDER et al., 2004).

Após catalisar a reação de formação de tricodieno (Tri5), o gene TRI 4 é responsável por várias oxigenações formando o metabólito intermediário isotricotiol. Este é convertido em isotricodermina pela acetiltransferase codificado pelo gene TRI101. Essa reação reduz a toxicidade do tricoteceno, um mecanismo de autoproteção do fungo contra os metabólitos tóxicos. Após este evento ocorre adição de grupo hidroxil controlado por TRI11 que em seguida é acetilado por TRI3 levando a formação de calonectrina. Essas etapas são comuns a ambos os tricotecenos tipo A (T-2) e tipo B (DON). Depois, ocorrem reações que irão resultar nos diferentes quimiotipos (DON, 3-ADON, 15-ADON e NIV). Em F. graminearum os genes TRI7 e TRI13 são funcionais somente em isolados produtores de NIV. Sua continuação da via gera o produto 4-acetilnivalenol (TRI1) e uma última etapa gera a formação de NIV pelo transcrito do gene TRI8. Em isolados produtores de DON, os genes TRI7 e TRI13 não são funcionais. Após a formação de colonectrina, o produto de TRI8 é responsável por remover o grupo C-3 acetil ou C-15 acetil, resultando em um dos derivados 15-ADON e 3-ADON. A formação de 3ADON ou 15ADON é específica do isolado, dependendo da sequência de TRI8 que codifica a esterase (MERHEJ; FORGET; BARREAU, 2011). Após os derivados ocorre a formação de DON. Entretanto, muitos mecanismos de síntese ainda não estão completamente elucidados. Por exemplo, sabe-se que o gene TRI12 tem como função bomba de efluxo para retirada dos metabólitos (ALEXANDER et al., 1999), porém não há informação concreta do momento que ele ocorre na via.

Outros três genes importantes para síntese são os reguladores TRI6, TRI10 e TRI15. O gene TRI6 é um forte regulador positivo da via de biossíntese. Ele codifica um fator de transcrição zinco de dedo $\mathrm{Cys}_{2} \mathrm{His}_{2}$ que atua nos demais genes da via. Seu silenciamento diminui drasticamente a produção de tricotecenos dentro do fungo (DESJARDINS, 2006; MCCORMICK et al., 2011). O gene TRI10 aparenta co-regular com TRI6 diversos genes da via, contudo ele parece regular o próprio 
TRI6 (PEPLOW et al., 2003; TAG et al., 2001). O gene TRI15, também codifica um fator de transcrição dedo de zinco, porém acredita-se que ele possua o papel inverso e regule negativamente a via de biossíntese (ALEXANDER, et al., 2004). Mesmo bem caracterizada a via de biossíntese ainda não esta completamente esclarecida, estudos já demonstraram que genes globais, que atuam em diferentes locais dentro do fungo também regulam a expressão de tricotecenos.

\subsubsection{Reguladores globais de tricotecenos}

A produção de tricotecenos é impactada por vários reguladores fora da via principal de biossíntese. Esses reguladores atuam de forma global, principalmente sob mudança de fatores abióticos como pH, luz e perfil nutricional.

$\mathrm{O} \mathrm{pH}$ é possivelmente o fator que mais afeta a biossíntese de tricotecenos. Estudos já demonstraram que em culturas in vitro de $F$. graminearum em meio mínimo, o fungo acidifica o substrato e ambos, produção de tricotecenos e expressão dos genes TRI, aumentam diante da redução de pH (GARDINER et al., 2009; MERHEJ et al., 2010).

Outro fator abiótico importante na regulação é a luz. A ativação ou modificações de vias de biossíntese em fungos ocorrem em contato com a luz. A proteína regulatória de luz é a $\vee e A$, codificada pelo gene Velvet. A proteína $V e A$ faz parte do complexo proteico VelB/VeA/LaeA localizado dentro do núcleo em condições de escuro (BAYRAM, et al., 2008). Além de atuarem no processo de frutificação e metabolismo de carotenoides, polissacarídeos e ácidos graxos, estudos já demonstraram que diversas micotoxinas são reguladas pela ação da luz. As proteínas VeA e LaeA parece possuir papel central na regulação mediada pela luminosidade. VeA é uma proteína conservada e seus ortólogos foram encontrados em diversos fungos micotoxigênicos. A deleção de FVVE1 em F. verticillioides suprimiu completamente a produção de fumonisina (MYUNG et al., 2009). Em $F$. graminearum a desrupção do gene $F g V e 1 D$ afetou a capacidade do fungo de expressar diversos genes TRI e produzir tricotecenos. O crescimento do fungo, o desenvolvimento dos conídeos e biossíntese anormal de aurofusarina também foi afetado (MERHEJ; FORGET; BARREAU, 2012). 
Fontes nutricionais também apresentam um papel regulatório importante na produção de micotoxinas. A fonte de carbono parece influenciar os níveis de tricotecenos em culturas de $F$. graminearum. Os dados mostram que $F$. graminearum produz mais tricoteceno em substrato com sacarose que com glicose, indicando a preferência por fontes mais simples de metabolizar que fontes mais complexas (JIAO et al., 2008). Comportamentos similares também foram descritos nas espécies $F$. asiaticum e $F$. avenaceum (AKIRA et al., 2014; SORENSEN; GIESE, 2013). O mecanismo é conhecido como "repressão de carbono" e implica que a proteína repressora CreA na presença de glicose inibe a transcrição de diversos genes quando se liga a sequências especificas na região promotora dos genes alvo (RONNE, 1995). A sequência consenso de ligação de CreA foi encontrada numa região intergênica entre TRI4 e TRI6 em F. graminearum, indicando que a repressão de genes por CreA também deve ocorrer em tricotecenos (MERHEJ; FORGET; BARREAU, 2012).

\subsection{Zearalenona}

Zearalenona é uma lactona de ácido resorcíclico, estrogênica não esteroidal biosintetizada por cepas do complexo F. graminearum, e espécies próximas como F. crookwellense e F. culmorum (DESJARDINS, 2006). Seu nome é originado da combinação de G.zeae (espécie fúngica onde a toxina foi primeiramente isolada em 1966) e sua estrutura química - lactona de ácido resorciclico. É estável e dificilmente degradada no processo de fabricação de alimentos e rações (JOINT FAO/WHO EXPERT COMMITTEE ON FOOD ADDITIVES - JECFA, 2000). ZEA é o metabólito mais encontrado do grupo, porém $\alpha$ - zearalenol ( $\alpha$-ZEA), $\beta$-zearalenol ( $\beta$-ZEA) e 4-acetilzearalenona também podem ser encontrados naturalmente em cereais (DESJARDINS, 2006). O metabólito a-zearalanol é também comercializado como estimulante de gado, porém está banido da União Europeia desde 1985 (JECFA, 2000). 


\subsubsection{Efeitos nocivos da zearalenona}

Sua relevância tem sido apontada por possui forte efeito estrogênico devido sua alta afinidade com os receptores de estrogênio de animais e humanos (KUIPER et al., 1998). Todos seus metabólitos têm semelhanças estruturais suficientes com o estrogênio natural de humanos e animais. Isso garante sua capacidade de ativar os receptores levando a alterações de genes ligados ao estrogênio (PARVEEN et al., 2009). Diversos efeitos nocivos são atribuídos a ingestão de ZEA principalmente após exposição crônica. Ela está associada principalmente a alterações nos órgãos envolvidos com a reprodução, e já foi associada a carcinomas, hiperplasia do útero, diminuição de fertilidade, e modificação da próstata em animais (COLDHAM, et al 1997; ZINEDINE, et al., 2007). Também há relatos de seu efeito genotóxico em culturas de linfócito bovino in vitro (LIOI et al., 2004) como também fragmentação de DNA e produção de micronúcleo em células Caco-2 e VERO (rim de macaco) (ABID-ESSEFI et al., 2003). Estudos também indicam que ZEA pode apresentar um papel importante em tumores dependentes de hormônios (TOMASZEWSKI et al., 1998; WITHANAGE et al., 2001). Ela foi detectada no tecido de mulheres com hiperplasia e adenocarcinoma endometrial (TOMASZEWSKI et al., 1998) como também foi associada ao desenvolvimento sexual precoce de meninas na região da Toscana, Itália (MASSART et al., 2008). Seu metabólito a-ZEA já foi associado ao desenvolvimento de câncer de mama (BELHASSEN et al., 2015).

\subsubsection{Metabolismo de zearalenona}

Pouco se sabe sobre como a toxina é metabolizada no organismo. Acreditase que após a ingestão oral, ZEA é rapidamente absorvida pelas células intestinais e metabolizada no fígado. ZEA então pode ser transformada em $\alpha$-ZEA, $\beta$-ZEA, $\alpha$ ZAL ( $\alpha$-zearalanol) e $\beta$-ZAL ( $\beta$-zearalenol) (MILES et al., 1996). Entretanto os metabólitos encontrados no tecido hepático e na bile diferem em proporção de acordo com a espécie estudada. Humanos e porcos convertem a maioria de ZEA em $\alpha$-ZEA, já em gados o metabólito predominante é $\beta$-ZEA (MALEKINEJAD; MASS-BAKKER; FINK-GREMMELS, 2006; PILLAY et al., 2002; VIDEMANN et al., 2008). Parte dos metabólitos é então conjugada com ácido sulfônico ou glucorônico, diminuindo significantemente a capacidade estrogênica dos mesmos, possivelmente 
uma forma do organismo de evitar a interação desses compostos com seus receptores (FRIZZELL et al., 2015). A conjugação também garante um aumento na solubilidade o que os leva a serem excretados mais facilmente pela urina (ZINEDINE et al., 2007).

\subsubsection{Biossíntese e aspectos moleculares de zearalenona}

A síntese de ZEA ainda não foi bem definida, mas sabe-se que é formada por um cluster que envolve ao menos quatro genes: ZEB1, ZEB2 e dois genes PKSs (policetídeos sintetase) - PKS13 e PKS4. PKSs são conhecidos por catalisarem a biossíntese de policetídeos, que são uma classe abundante e variada de compostos naturais como antibióticos, toxinas e pigmentos (KELLER; HOHN, 1997).

A via biossintética de ZEA começa por PKS4 que catalisa a condensação de acetil-coA e cinco unidades de malonyl-CoA formando um hexacetídeo. O produto do gene PKS13 extende o hexacetídeo resultando num nonacetídeo. Este passa por duas reações de ciclizações que leva a formação de um anel aromático e depois a formação de um anel macrolideo gerando o composto zearalenol (ZOL). A última etapa converte o recém-formado ZOL em ZEA e é catalisada por ZEB1 que por oxidação converte hidroxila em cetona. A proteína ZEB2 é um fator de transcrição que contém um domínio zipper leucina e parece funcionar como um regulador da expressão dos genes do cluster (KIM et al., 2005).

\subsection{Legislação para desoxinivalenol e zearalenona}

Como um dos maiores produtores e exportadores de grãos do mundo, 0 Brasil teve que se adequar as exigências e normas envolvendo níveis de micotoxinas em alimentos e rações.

Em 2011, a Agência Nacional de Vigilância Sanitária (ANVISA) publicou no Diário da União a portaria $\mathrm{RDCn7}$ regulamentando o limite máximo tolerado (LMT) de diversas micotoxinas (aflatoxina, fumonisina, patulina, etc) presentes em diferentes alimentos, limites estes, que não havia anteriormente. O quadro 1 mostra os LMT das toxinas DON e ZEA em vigor desde 2012. Entretanto, a partir de 2017, os limites serão mais rigorosos como também será incluído a análise de grãos de 
trigo e milho pré-processados. Originalmente, a data para inclusão de grãos e novos limites de micotoxinas seria em 2014, porém, os novos limites foram postergados para o ano 2017 na resolução RDC n59 (ANVISA, 2013).

\section{Quadro 1 - Limites máximos tolerados de acordo com a resolução RDCn7 estipulada pela ANVISA com aplicação a partir de 2012 e 2017.}

\begin{tabular}{|c|c|c|c|}
\hline Micotoxinas & Alimentos & $\begin{array}{l}2012 \\
\operatorname{LMT}(\mu \mathrm{g} / \mathrm{kg})\end{array}$ & $\begin{array}{l}2017 \\
\mathrm{LMT}(\mu \mathrm{g} / \mathrm{kg})\end{array}$ \\
\hline \multirow[b]{2}{*}{ DON } & $\begin{array}{l}\text { Trigo em grãos e milho para posterior } \\
\text { processamento }\end{array}$ & $\mathrm{nr}$ & 3000 \\
\hline & $\begin{array}{l}\text { Trigo integral, trigo para quibe, farinha de trigo } \\
\text { integral, farelo de trigo, farelo de arroz, grão de } \\
\text { cevada } \\
\text { Farinha de trigo, massas, crackers, biscoitos de } \\
\text { água e sal, e produtos de panificação, cereais e } \\
\text { produtos de cereais exceto trigo e incluindo } \\
\text { cevada maltada. }\end{array}$ & 1750 & 1000 \\
\hline \multirow{7}{*}{ ZEA } & $\begin{array}{l}\text { Trigo em grão e milho para posterior } \\
\text { processamento }\end{array}$ & $\mathrm{nr}$ & 400 \\
\hline & $\begin{array}{l}\text { Trigo integral, farinha de trigo integral, farelo de } \\
\text { trigo }\end{array}$ & 400 & 200 \\
\hline & $\begin{array}{l}\text { Farinha de trigo, massas, crackers e produtos } \\
\text { de panificação, cereais e produtos de cereais } \\
\text { exceto trigo e incluindo cevada malteada }\end{array}$ & 200 & 100 \\
\hline & Arroz beneficiado e derivados & 200 & 100 \\
\hline & Arroz integral & 800 & 400 \\
\hline & $\begin{array}{l}\text { Milho de pipoca, canjiquinha, canjica, produtos e } \\
\text { subprodutos à base de milho }\end{array}$ & 300 & 150 \\
\hline & Farelo de arroz & 1000 & 500 \\
\hline
\end{tabular}

nr- não regulamentado

Para grãos de trigo o LMT a partir de 2017 será de 3000 e $400 \mu \mathrm{g} / \mathrm{kg}$ para DON e ZEA, respectivamente. Em trigo integral e farinhas, o limite máximo será de $1000 \mu \mathrm{g} / \mathrm{kg}$ para DON e $200 \mu \mathrm{g} / \mathrm{kg}$ para ZEA (Quadro 1). É importante destacar que em outros países os LMT tendem a ser mais rigorosos. Na União Europeia, para grãos de trigo o máximo permitido é de $1750 \mu \mathrm{g} / \mathrm{kg}$ para DON e $100 \mu \mathrm{g} / \mathrm{kg}$ para ZEA (EC, 2006). No Canadá e China o LMT para grãos de DON é de 2000 e $1000 \mu \mathrm{g} / \mathrm{kg}$, respectivamente (CANADIAN FOOD INSPECTION - CFIA, 2012; USDA, 2011). 
Mesmo com níveis mais flexíveis, a regulamentação dos LMT para micotoxinas foi um grande avanço para os consumidores como para a indústria brasileira. 


\section{MATERIAIS E MÉTODO}

\subsection{Amostragem do trigo}

Foram utilizados grãos de trigo recém-colhidos provenientes de três regiões produtoras: Rio Grande do Sul (50), Paraná (50) e São Paulo (50) totalizando 150 amostras de $1 \mathrm{~kg}$ cada. As coletas foram realizadas durante os meses de setembro (Nova Itacolomi - PR), outubro (Campo Bonito- SP) e novembro (Passo Fundo Rio Grande do Sul) de 2012. Essa variação ocorreu devido às variedades específicas de trigo plantadas em cada região, como também variações climáticas de cada estado.

\subsection{Atividade de Água (Aa)}

A atividade de água das 150 amostras de grãos de trigo foram medidas no equipamento CX-2 AquaLAB.

\subsection{Isolamento e identificação da micobiota de amostras de grãos de trigo}

Os isolamentos foram realizados dentro do período de uma semana a partir da coleta dos grãos pela técnica de semeadura direta (BERJAK, 1984). Os grãos foram desinfectados em solução de hipoclorito de sódio (1\%) por 1 minuto e enxaguados com água destilada. Tal procedimento foi utilizado para eliminação dos contaminantes externos. Por amostra, 100 grãos foram selecionados ao acaso e semeados diretamente em placas de Petri contendo meio Batata Dextrose Ágar (BDA), meio este, indicado pelo The Fusarium Laboratory Manual para o isolamento de Fusarium em trigo (LESLIE; SUMMEREL, 2006). Foram utilizadas, para cada uma das amostras, 10 placas contendo 10 grãos cada, totalizando 500 placas por região produtora (Figura 1). Todas as placas foram incubadas a $25{ }^{\circ} \mathrm{C}$ por 7 dias. Para a manutenção, as cepas foram liofilizadas e também mantidas em meio BDA. As colônias de diferentes tipos morfológicos foram isoladas em submetidas à identificação através da técnica de microcultivo (RIDDELL, 1950). 
Figura 1 - Isolamento fúngico de grãos de trigo.

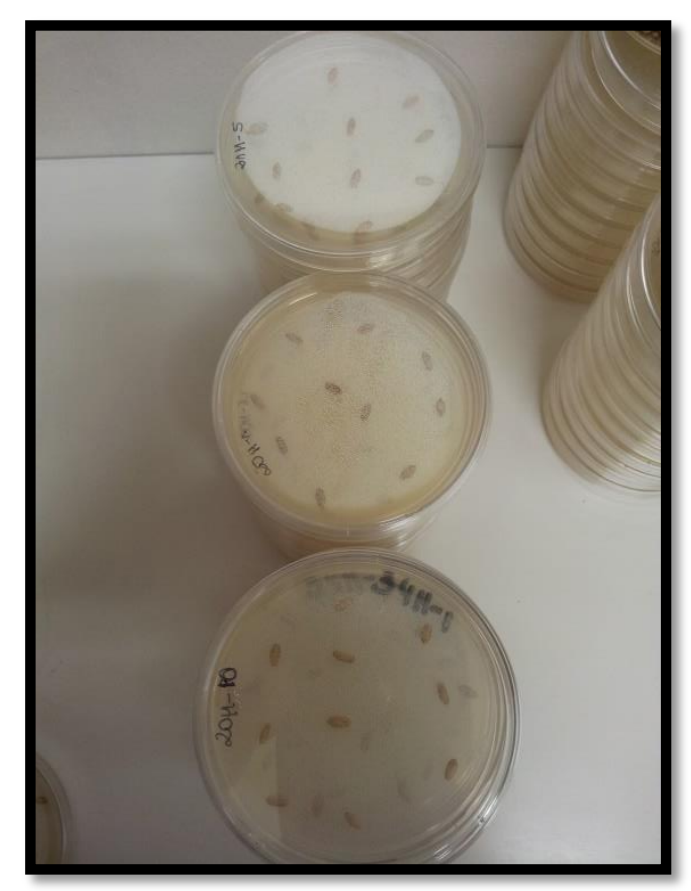

\subsection{Identificação dos fungos não esporulados (FNE)}

\subsubsection{Extração do DNA genômico}

Para a obtenção da biomassa fúngica, as cepas selecionadas foram semeadas em meio de cultura YES - Extrato de levedura, Sacarose e Ágar (Oxoid) e incubadas em placa de Petri por três dias a $25^{\circ} \mathrm{C}$. Após esse período, o micélio foi macerado e o DNA extraído conforme o manual de instruções do kit EasyDNA (Invitrogen).

\subsubsection{Identificação dos gêneros FNE pelo sequenciamento parcial da região espaçadora interna transcrita (ITS)}

A identificação foi realizada através do sequenciamento utilizando os iniciadores ITS1 - TCCGTAGGTGAACCTGCG e ITS 4 TCCTCCGCTTATTGATAT (WHITE et al., 1990). Os fragmentos foram amplificados em termociclador Applied Biosystems Thermocycler GeneAmp R9700. O volume 
total da reação foi de $25 \mu \mathrm{l}$, utilizando-se buffer 1 x, 2,5 mM de MgCl2, dNTP a 0,2 $\mathrm{mM}$, iniciadores a $0,3 \mathrm{mM}$, Taq DNA polimerase a $0,04 \mathrm{U} / \mu \mathrm{l}$ e $3 \mu \mathrm{l}$ do DNA concentrado $(90 \mathrm{ng} / \mu \mathrm{L})$. Os parâmetros da amplificação foram: $94{ }^{\circ} \mathrm{C}(3$ minutos $)$ para a desnaturação inicial, 25 ciclos a $94{ }^{\circ} \mathrm{C}$ (1 minuto), $56{ }^{\circ} \mathrm{C}$ (1 minuto), $72^{\circ} \mathrm{C}(1$ minuto) e um ciclo adicional de $72 \stackrel{\circ}{\circ} \mathrm{C}$ (7 minutos) para extensão final. Os produtos da reação foram visualizados por eletroforese em gel de agarose $(1,2 \%)$ com TBE $0,5 \mathrm{x}$ e corados com safe DNA (Invitrogen). O marcador de peso molecular utilizado foi de $1 \mathrm{~Kb}$ DNA ladder (Invitrogen).

\subsubsection{Reação de sequenciamento}

A reação de sequenciamento foi realizada em termociclador Applied Biosystems Thermocycler GeneAmp R9700, utilizando 0,8 $\mu \mathrm{L}$ do BigDyeTerminator v3.3. (Applied Biosystems), $3 \mu \mathrm{L}$ do tampão para BigDye, $1 \mu \mathrm{L}$ do iniciador $(4 \mu \mathrm{M})$, $10 \mu \mathrm{L}$ de água MilliQ esterilizada e $1 \mu \mathrm{L}$ de DNA (10 a $20 \mathrm{ng}$ ). As condições da reação foram: $95{ }^{\circ} \mathrm{C}$ (2 minutos), 25 ciclos de $96{ }^{\circ} \mathrm{C}$ (20 segundos), $55^{\circ} \mathrm{C}$ (20 segundos) e $60{ }^{\circ} \mathrm{C}$ (4 minutos). Após a reação, as amostras foram purificadas utilizando $60 \mu \mathrm{L}$ de isopropanol $100 \%$ e $30 \mu \mathrm{L}$ de agua MilliQ, em seguida, incubadas por 15 minutos a temperatura ambiente. Após centrifugação por 14000 rpm (25 minutos), o sobrenadante foi descartado e $150 \mu \mathrm{L}$ de isopropanol $75 \%$ adicionados. O material foi centrifugado novamente a $14000 \mathrm{rpm}$ por 10 minutos, o sobrenadante descartado e o tubo seco em Speed Vacum. As amostras foram ressuspendidas em formamida $\mathrm{Hi}$ - $\mathrm{Di}$ (Applied Biosystems), desnaturadas a $95^{\circ} \mathrm{C}(2$ minutos) e incubadas em gelo (1 minuto). Em seguida foram aplicadas as colunas capilares contendo o polímero POP6 no sequenciador automático Abi Prism $R$ Genetic Analyser (Applied Biosystems). As sequências foram editadas utilizando o software BioEdit v7.0.9.0 e posteriormente alinhadas com o Blast dos bancos de dados, GeneBank (http://blast.ncbi.nlm.nih.gov/Blast.cgi). 


\subsection{Identificação dos isolados de Microdochium spp}

Para a identificação foram utilizados os iniciadores específicos para as espécies Microdochium nivale: Y13NF- ACCAGCCGATTTGTGGTTATG;Y13NRGGTCACGAGGCAGAGTTCG $(310 \mathrm{pb})$ e $M$. majus: Mnm2FTGCAACGTGCCAGAAGCT ; Mnm2R- AATCGGCGCTGTCTACTAAAAGC (750 pb) (NICHOLSON et al., 1996).Os parâmetros de amplificação foram: $94{ }^{\circ} \mathrm{C}(5$ minutos), ciclo de 35 vezes de $94{ }^{\circ} \mathrm{C}$ (30 segundos), $60{ }^{\circ} \mathrm{C}$ ( 1 minuto), $72{ }^{\circ} \mathrm{C}$ ( 1 minuto) e ciclo final de $72{ }^{\circ} \mathrm{C}$ (7 minutos). $\mathrm{O}$ volume total da reação foi de $25 \mu \mathrm{L}$, utilizando-se buffer 1 x, 2,5 mM de MgCl2, dNTP a 0,31 mM, iniciadores a 0,63 mM, Taq DNA polimerase a $0,04 \mathrm{U} / \mu \mathrm{L}$ e $2,5 \mu \mathrm{L}$ do DNA concentrado $(90 \mathrm{ng} / \mu \mathrm{L})$.

\subsection{Identificação dos isolados de Fusarium spp}

Para a identificação foram utilizados os iniciadores $E F-1 \alpha \quad F \quad$ ATGGGTAAGGARGACAAGAC e EF-1 $\alpha$ R - GGARGTACCAGTSATCATGTT (O'DONNEL et al., 1997). Os parâmetros de amplificação foram: $94{ }^{\circ} \mathrm{C}$ (5 minutos), ciclo de 35 vezes de $94{ }^{\circ} \mathrm{C}$ (30 segundos), $56{ }^{\circ} \mathrm{C}$ (1 minuto), $72{ }^{\circ} \mathrm{C}$ (1 minuto) e ciclo final de $72{ }^{\circ} \mathrm{C}$ (7 minutos). A etapa de extração, purificação e reação de sequenciamento foram idênticas às descritas nos itens 4.4.

\subsection{Identificação dos genótipos de tricotecenos tipo B dos isolados do Complexo de espécie de F. graminearum}

\subsubsection{Reação de PCR}

Após a extração do DNA genômico como descrito no item 4.4.1, foram realizados as análises dos genótipos de tricotecenos. Os parâmetros de amplificação foram: $95^{\circ} \mathrm{C}$ ( 1 minuto), ciclo de 25 vezes de $95^{\circ} \mathrm{C}$ (30 segundos), 52 ${ }^{\circ} \mathrm{C}$ (30 segundos), $72{ }^{\circ} \mathrm{C}$ (30 segundos) e ciclo final de $72{ }^{\circ} \mathrm{C}$ (7 minutos). O volume total da reação foi de $25 \mu \mathrm{L}$, utilizando-se buffer 1 x, 2,5 mM de MgCl2, dNTP a 0,31 
$\mathrm{mM}$, iniciadores a 0,56 mM , Taq DNA polimerase a 0,04 $\mathrm{U} / \mu \mathrm{L}$ e 2,5 $\mu \mathrm{L}$ do DNA concentrado (90 ng/ $\mu \mathrm{L})$. A quadro 2 mostra os iniciadores utilizados.

Quadro 2 - Iniciadores utilizados para identificação dos genótipos de tricotecenos.

\begin{tabular}{|c|c|c|c|c|c|}
\hline Reação & Iniciador & Sequência $5^{\prime}-3^{\prime}$ & Genótipo & $\begin{array}{l}\text { Fragmento } \\
\text { (pb) }\end{array}$ & Referência \\
\hline \multirow{5}{*}{$\begin{array}{l}\text { Multiplex } \\
\text { TRI12 }\end{array}$} & $12 \mathrm{con}$ & CATGAGCATGGTGATGTC & & & \multirow{5}{*}{$\begin{array}{l}\text { Ward et al., } \\
2002\end{array}$} \\
\hline & & & NIV & 840 & \\
\hline & $12 n f$ & TCTCCTCGTTGTATCTGG & & & \\
\hline & $12-15 f$ & TACAGCGGTCGCAACTTC & 15-ADON & 670 & \\
\hline & $12-3 f$ & CTTTGGCAAGCCCGTGCA & 3-ADON & 410 & \\
\hline \multirow{2}{*}{$\begin{array}{l}\text { TRI13- } \\
\text { DON }\end{array}$} & & $\begin{array}{l}\text { CATCATGAGACTTGTGTCAG } \\
\text { AGTTTGGG }\end{array}$ & \multirow{2}{*}{ DON } & \multirow{2}{*}{282} & \multirow{2}{*}{$\begin{array}{l}\text { Chandler et } \\
\text { al., } 2003\end{array}$} \\
\hline & tri13don-r & $\begin{array}{l}\text { GCTAGATCGATTGTTGCATT } \\
\text { GAG }\end{array}$ & & & \\
\hline TRI13-NIV & $\begin{array}{l}\text { triniv-f } \\
\text { tri13-r }\end{array}$ & $\begin{array}{l}\text { CCAAATCCGAAAACCGCAG } \\
\text { TTGAAAGCTCCAATGTCGTG }\end{array}$ & NIV & 312 & $\begin{array}{l}\text { Chandler et } \\
\text { al., } 2003\end{array}$ \\
\hline
\end{tabular}

\subsection{Identificação dos genótipos de tricotecenos tipo B de grãos de trigo}

\subsubsection{Amostragem de grãos de trigo}

Das 150 amostras de grãos de trigo utilizadas no isolamento fúngico e análise de tricotecenos, foram escolhidas aleatoriamente 75 amostras (25 por região) para análise dos genótipos.

\subsubsection{Extração de DNA genômico}

Para a análise de cada amostra foi utilizado $100 \mathrm{~g}$ de trigo moído. Depois de homogeneizado, uma alíquota de $0,5 \mathrm{mg}$ de cada amostra foi separada para extração de DNA. Para maior maceração e quebra de parede, os grãos já moídos foram colocados em microtubo de $2 \mathrm{~mL}$ juntamente com uma pérola de $3 \mathrm{~mm}$ de aço e agitadas a 50 rpm por 3 minutos no equipamento TissueLyser LT (Qiagen) . 
Após esse período, o DNA foi extraído conforme o manual de instruções do kit EasyDNA (Invitrogen).

\subsubsection{Reação de amplificação por PCR quantitativa (qPCR)}

As condições para a termociclagem foram: $50{ }^{\circ} \mathrm{C}$ (2 minutos), $95{ }^{\circ} \mathrm{C}(2$ minutos), 40 ciclos a $95{ }^{\circ} \mathrm{C}$ ( 15 segundos), e $60{ }^{\circ} \mathrm{C}$ por (30 segundos). $O$ reagente Platinum SYBR Green QPCR SuperMix - UDG (Invitrogen) foi utilizado na reação, adicionando $250 \mathrm{nM}$ de cada iniciador, $6,25 \mu \mathrm{L}$ do reagente $S y b r, 0.1 \mu \mathrm{g} / \mu \mathrm{L}$ de BSA e $0.25 \mu \mathrm{L}$ de ROX e $2,5 \mu \mathrm{L}$ da fita de cDNA (40 $\mathrm{ng} / \mu \mathrm{L}$ ) totalizando um volume de 13 $\mu \mathrm{L}$. Os iniciadores foram analisados em duplicata no equipamento Step One Plus Real - Time PCR Systems (Applied Biosystems). Para a exclusão de possíveis contaminações, em todas as reações, foi utilizado um controle negativo apropriado.

\subsubsection{Validação da técnica}

A metodologia utilizada foi desenvolvida por Nielsen et al. (2012). Para validação da técnica foi realizado as curvas de eficiência dos iniciadores utilizados (Quadro 3). O cálculo da eficiência foi realizado pelo fórmula $E=10^{(-1 / \text { slope) }}-1$. O slope é o resultado da relação linear entre as concentrações em $\log _{10}$ de DNA e o número de ciclos do ensaio (Ct). Depois, foram realizadas curvas padrão com cinco pontos de diluição. As concentrações variaram entre 150 a $10 \mathrm{ng} / \mu \mathrm{L}$. O DNA utilizado para a curva padrão foi previamente quantificado em espectrofotômetro Nanodrop 2000 UV-VIS (Thermo Fisher, USA). Os genótipos (3-ADON, 15-ADON e NIV) das cepas utilizadas para validação foram determinados previamente como descritos no item 4.7

Para o cálculo da concentração de DNA alvo encontrado nos grãos de trigo foram utilizadas as curvas padrão como referência. Com intuito de evitar erros de quantificação devido à degradação do DNA no trigo, todas as quantificações do DNA fúngico foram normalizadas utilizando o gene Fator de elongação- $1 \alpha$ de planta (Hor1/Hor2) (Quadro 3). As análises estatísticas foram realizadas no software InStat (GraphPad, 2009, v. 3.10) pelo coeficiente de correlação de Spearman. 
Quadro 3 - Iniciadores utilizados para detecção dos genótipos de tricotecenos em grãos de trigo

\begin{tabular}{|c|c|c|c|c|}
\hline Iniciador & Sequência $5{ }^{`}-3{ }^{`}$ & Alvo & $\begin{array}{l}\text { Tm } \\
\text { (ㅇ) }\end{array}$ & Referência \\
\hline 3ADONf & AACATGATCGGTGAGGTATCGA & \multirow{2}{*}{ 3ADON } & \multirow{2}{*}{80} & \\
\hline $3 A D O N r$ & CCATGGCGCTGGGAGTT & & & \\
\hline 15ADONf & GTTTCGATATTCATTGGAAAGCTAC & \multirow{2}{*}{ 15ADON } & \multirow{2}{*}{70} & Nielsen, et \\
\hline 15ADONr & CAAATAAGTATCGTCTGAAATTGGAAA & & & al., 2012 \\
\hline NIVf & GCCCATATTCGCGACAATGT & \multirow{2}{*}{ NIV } & \multirow{2}{*}{78.7} & \\
\hline NIVr & GGCGAACTGATGAGTAACAAAACC & & & \\
\hline Hor1f & TCTCTGGGTTTGAGGGTGAC & \multirow{2}{*}{ HOR } & \multirow{2}{*}{78.5} & Nicolaisen, \\
\hline Hor2r & GGCCCTTGTACCAGTCAAGGT & & & et al., 2009 \\
\hline
\end{tabular}

$\mathrm{Tm}$ - temperatura de melting.

\subsection{Expressão gênica de tricotecenos por PCR quantitativa (qPCR)}

\subsubsection{Cultivo e isolamento de RNA}

Foram cultivadas 42 cepas do CEFG - 19 F. graminearum, 17 cepas de $F$. meridionale, $3 F$. cortaderiae e 3 de $F$. austroamericanum - em meio de ágar YES (extrato de levedura, sacarose e). O RNA total foi isolado utilizando o Kit RNeasy (Qiagen), de acordo com o manual de instruções, em seguida, o cDNA foi sintetizado utilizando o Kit Sensiscript RT (Qiagen). Cada $20 \mu \mathrm{L}$ de reação possuem $10 \mu \mathrm{L}$ do produto de extração de RNA total, $2 \mu \mathrm{L}$ de Random primers $(3 \mu \mathrm{g} / \mu \mathrm{L}$ Invitrogen), $2 \mu \mathrm{L}$ de 10X RT-PCR buffer, $2 \mu \mathrm{L}$ de dNTP mix, $1 \mu \mathrm{L}$ de inibidor de

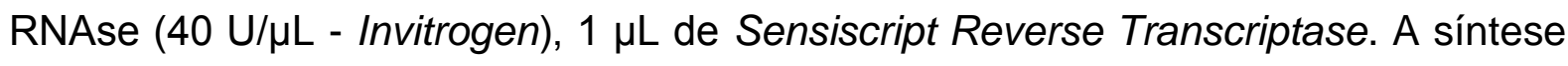
do cDNA foi realizada no Step One Plus Real - Time PCR Systems (Applied Biosystems) por $2 \mathrm{~h}$ a $37^{\circ} \mathrm{C}$. As amostras foram mantidas a $-20^{\circ} \mathrm{C}$. 


\subsubsection{Reação de amplificação dos genes TRI envolvidos na via biossintética de tricotecenos}

Foram escolhidos 5 genes, com função conhecida, responsáveis pela produção de tricotecenos em F. graminearum: TRI4, TRI5, TRI6, TRI12 e TR/101. Os iniciadores foram obtidos a partir do programa Primer 3 (Quadro 4). As condições para a termociclagem foram: $50{ }^{\circ} \mathrm{C}$ (2 minutos), $95{ }^{\circ} \mathrm{C}$ (2 minutos), 40 ciclos a $95{ }^{\circ} \mathrm{C}$ (15 segundos), e $60{ }^{\circ} \mathrm{C}$ por (30 segundos). $\mathrm{O}$ reagente Platinum SYBR Green qPCR SuperMix - UDG (Invitrogen) foi utilizado na reação, adicionando $250 \mathrm{nM}$ de cada iniciador e 2,5 $\mu \mathrm{L}$ da fita de cDNA (concentração de 20 $\mathrm{ng} / \mathrm{mL}$ ), $6,25 \mu \mathrm{L}$ do reagente Sybr e $0,25 \mu \mathrm{L}$ de ROX, totalizando um volume de 12,5 $\mu \mathrm{L}$. Os iniciadores foram analisados em duplicata no equipamento Step One Plus Real - Time PCR Systems (Applied Biosystems). Para a exclusão de possíveis contaminações, em todas as reações, foi utilizado um controle negativo apropriado. A expressão relativa de cDNA foi normalizada utilizando o gene de referência Fator de elongação $1 \alpha(E F-1 \alpha)$ de fungo.

Quadro 4 - Iniciadores utilizados para análise da expressão gênica de tricotecenos

\begin{tabular}{ll}
\hline Iniciador & Sequência (5'-3') \\
\hline TRI4-F & CCTTGGGGTAGCCAACAATA \\
TRI4- - & GGCCTTTGCTGAGATGTACC \\
TRI5- F & GGAGCGTATCGAGAATTTGC \\
TRI5- R & TGCCCAACTGTATACGACCA \\
TRI6-F & CGGTGGATTCAACCAAGACT \\
TRI6-R & AGTCCCGACGATGTGGTTAT \\
TRI12-F & ATAAAGCTGATGCGGGACAT \\
TRI12-R & CATGGCACTGGGAGTCATT \\
TRI101-F & CGCATCAACAAAGTTCGTGT \\
TRI101-R & GCAGAGCCATCGATTCTTTC \\
\hline
\end{tabular}

\subsubsection{Análise da expressão gênica}

A quantificação relativa baseada nos valores de $\Delta \Delta \mathrm{Ct}$ foi a metodologia analítica de escolha para esse estudo. Neste método, fez-se uma comparação entre 


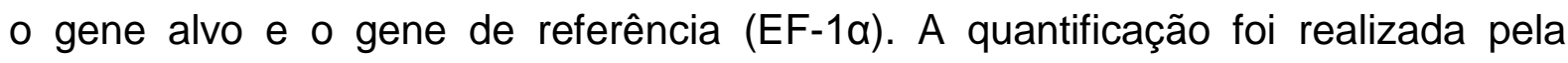
subtração do $\mathrm{Ct}$ alvo (ciclo em que a amostra ultrapassa o threshold) e o $\mathrm{Ct}$ do gene de referência, obtendo-se o $\Delta \mathrm{Ct}$. Em seguida, obteve-se o $\Delta \Delta \mathrm{Ct}$, pela subtração do $\Delta \mathrm{Ct}$ da amostra calibradora em relação à outra amostra. Para a validação do método, foram feitas diluições seriadas em triplicata do gene alvo e do gene de referência (EF-1 $\alpha)$. A partir da curva gerada pelo software, foi calculada a eficiência do ensaio através da fórmula: $E=10$ (-1/slope) -1 para cada gene. Em seguida, foi verificada a compatibilidade das eficiências geradas para os ensaios do gene alvo e do gene de referência. Após a realização das curvas de diluição, a média do Ct para as triplicatas de cada ponto da curva foi calculada, e posteriormente, o $\Delta \mathrm{Ct}$ foi calculado utilizando as médias de cada ponto e o log dos valores de diluição. Esses dados foram plotados em um gráfico para a verificação do slope da reta gerada (PFAFFL, 2001; SCHMITTGEN; LIVAK, 2008). Para análise estatística foi utilizado o coeficiente de correlação de Pearson utilizando o software Expression Suite v. 1.0.3 (Applied Technologies, USA).

\subsection{Detecção e quantificação de desoxinivalenol e zearalenona nos grãos de trigo}

\subsubsection{Solventes e reagentes utilizados}

Os padrões de micotoxinas (ZEA e DON) foram adquiridos na Sigma-Aldrich (St Loius, MO, USA). O solvente acetonitrila (grau HPLC) foi adquirido na J.T Baker (Phillisburg, NJ, USA) e a água utilizada foi purificada a partir do sistema Dlrect-QSystem ${ }^{\circledR}$ UV3 (Millipore, Bedford, USA).

\subsubsection{Extração das micotoxinas}

As extrações foram realizadas de acordo com Heidtmann-Bemvenuti et al. (2012). Foram pesados $10 \mathrm{~g}$ de amostra em um erlenmeyer $(8 \mathrm{~g}$ em peneira Mesh 32 e $2 \mathrm{~g}$ em peneira Mesh 60) de $250 \mathrm{~mL}$ e adicionados $20 \mathrm{~mL}$ de água destilada e $20 \mathrm{~mL}$ de acetonitrila acidificada com $0,2 \mathrm{~mL}$ de ácido acético glacial. A mistura foi 
levada ao agitador horizontal ( $5 \mathrm{~min} / 800 \mathrm{~g}$ ) e após foram adicionados os sais ( $1,5 \mathrm{~g}$ de sulfato de magnésio e $0,85 \mathrm{~g}$ de acetato de sódio) e agitada por 5 minutos. $\mathrm{O}$ extrato foi centrifugado (10 min/1400 g) e foram adicionados sais $(0,3 \mathrm{~g}$ de sulfato de magnésio e $0,2 \mathrm{~g}$ de celite) em $6 \mathrm{~mL}$ do sobrenadante, o qual foi agitado manualmente por 1 minuto. Foram coletados $3 \mathrm{~mL}$ do sobrenadante, que foi seco sob fluxo de nitrogênio. Para a quantificação, o resíduo seco foi ressuspenso em 1 $\mathrm{mL}$ da fase móvel e centrifugado a $1200 \mathrm{~g}$ (Eppendorf Centrifuge 5410, Hamburg, Germany).

\subsubsection{Instrumentação e condições cromatográficas de análise}

A técnica foi desenvolvida por Seus (2014) pelo Laboratório de Micotoxinas da Universidade Federal do Rio Grande - FURG. Foi utilizado um sistema de cromatografia líquida de ultra eficiência (UPLC) Shimadzu (Quioto, Japão) constituído por um sistema de bombas (modelo LC-AT), desgaseificador da fase móvel (modelo DGU), controlador (modelo CBM-20A), injetor manual com alça de amostragem de $20 \mu \mathrm{L}$ (modelo 7725i) e com dois sistemas de detecção espectrofotométrico, UV (modelo SPD-20A) e por fluorescência (modelo FL-10AXL). $O$ controle do equipamento e aquisição dos dados foi feito pelo software LC Solution. As análises foram realizadas utilizando-se uma coluna cromatográfica C18 Phenomenex ( $250 \times 4,6 \mathrm{~mm}$, com partículas de $5 \mu \mathrm{m}$ ), mantida em forno a $40^{\circ} \mathrm{C}$. A fase móvel utilizada foi constituída por água: acetonitrila (30:70, v/v), com eluição no modo isocrático e vazão de $0,5 \mathrm{~mL} \mathrm{~min}^{-1}$. O comprimento de onda para detecção de DON em UV foi de 220nm e para detecção de fluorescência de ZEA foi escolhido excitação e emissão a 350 e $450 \mathrm{~nm}$, respectivamente. Uma curva analítica foi construída entre as concentrações de 1 a $10 \mu \mathrm{g} / \mathrm{mL}$ para DON e 0,2 a $2 \mu \mathrm{g} / \mathrm{mL}$ para ZEA. A recuperação do método foi realizada em triplicata utilizando amostras contaminadas com diferentes concentrações de toxinas $(3 x, 5 x$ e $7 x$ os valores do Limite de Detecção) e posteriormente extraídas como descrito no item 4.10.1. As recuperações médias foram de $89 \%$ e $78 \%$ para DON e ZEA, respectivamente, Os resultados nas análises de micotoxinas foram confirmados através de cocromatografia utilizando as mesmas condições cromatográficas. 


\subsection{Análises estatísticas}

Todas as análises foram realizadas no software Prism 6 (GraphPad, 2014, v. 6.05). O método de análise de variância (ANOVA) foi utilizado para os resultados de contaminação fúngica e atividade de água. O teste Kruskal-Wallis foi escolhido para avaliar as diferenças nos níveis de concentração entre DON e ZEA nas regiões estudadas. Um valor de $p<0.05$ foi considerado estatisticamente significante. 


\section{RESULTADOS E DISCUSSÃO}

\subsection{Isolamento fúngico de grãos de trigo}

$\mathrm{Na}$ técnica de isolamento, foi constatado contaminação fúngica em $100 \%$ das 150 amostras de trigo provenientes das três regiões analisadas (Rio Grande do Sul, Paraná e São Paulo). A identificação dos fungos foi realizada, ao nível de gênero, utilizando morfológica clássica, porém, os fungos não esporulados (FNE) foram classificados pelo sequenciamento parcial da região ITS. A figura 2 mostra o perfil dos fungos isolados em cada região estudada. É possível observar que as amostras oriundas do RS e PR apresentam semelhança maior de perfil fúngico que a amostra do Estado de SP.

Figura 2 - Perfil de isolamento fúngico nos grãos de trigo provenientes dos Estados do Paraná, Rio Grande do Sul e São Paulo

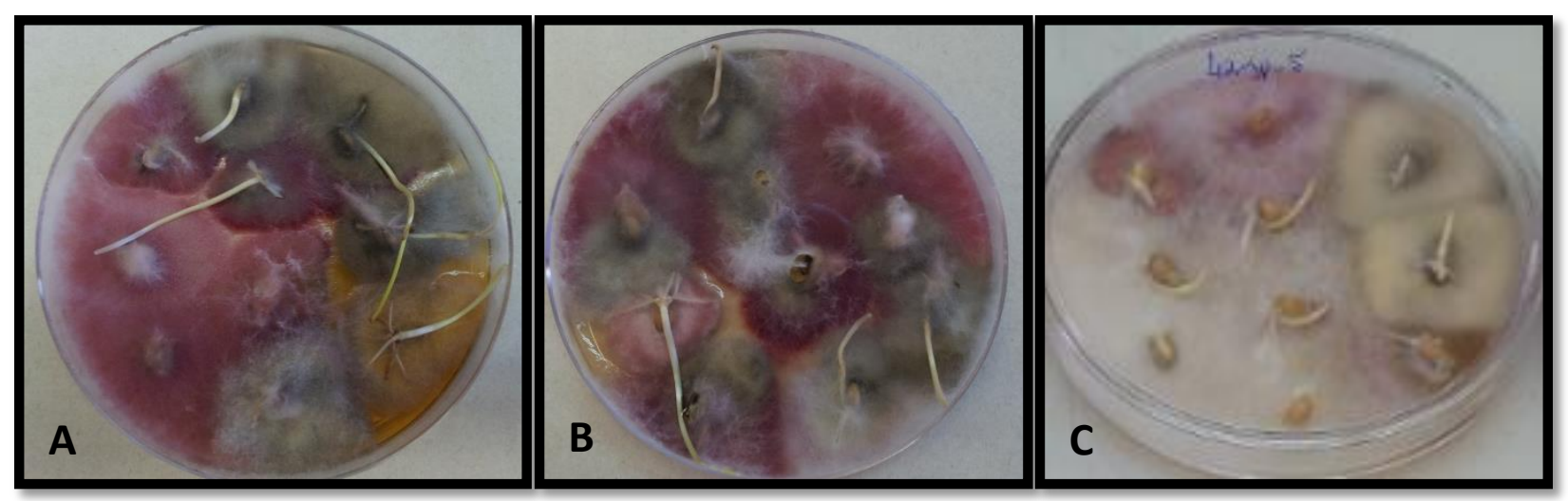

Nota: A - Paraná; B- Rio Grande do Sul; C- São Paulo.

Nossos resultados mostraram que no Rio Grande do Sul (RS), os gêneros mais frequentes foram Alternaria (49,7\%), Fusarium (42,8\%), Epicoccum (8.2\%) e Cladosporium (1.1\%) (Gráfico 1). Os valores de Aa dos grãos variaram entre 0.454 e 0.493 , e a Aa média foi de 0,473 . 
Gráfico 1 - Frequência de fungos isolados de grãos de trigo, provenientes dos Estados do Rio Grande do Sul, Paraná e São Paulo.

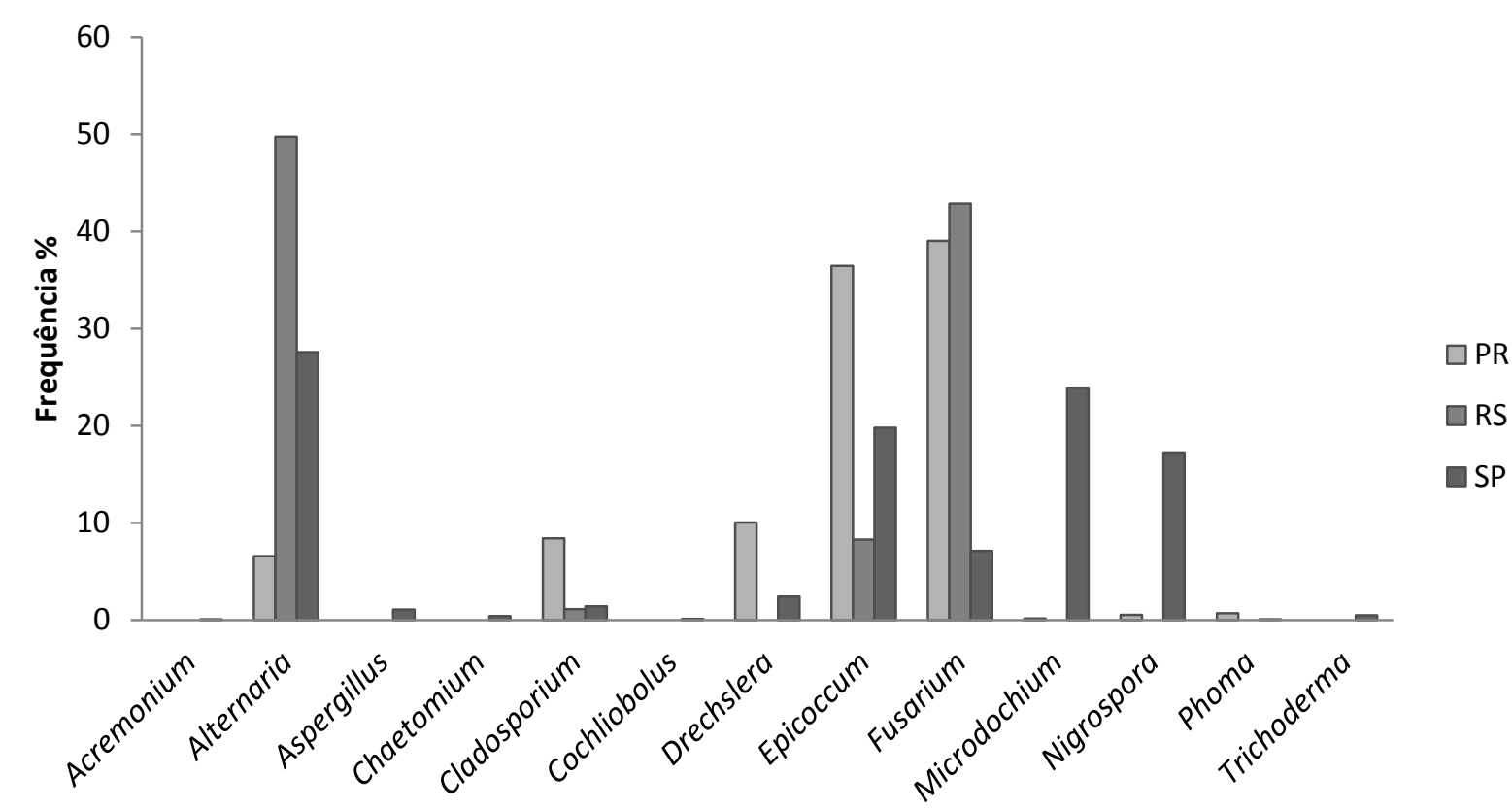

No Paraná (PR) as maiores contaminações encontradas foram por Fusarium (39\%), Epicoccum (36,4\%), Drechslera (10\%), Cladosporium (8.4\%) e Alternaria (6.5\%). Também foi observada a presença dos gêneros Nigrospora e Microdochium, com frequência abaixo de 1\% (Gráfico 1). Os valores de Aa variaram entre $0.638 \mathrm{e}$ 0.731, e a Aa média foi de 0,682.

Já no Estado de São Paulo (SP) foram isolados Alternaria (27,5\%), Microdochium (23,8\%), Epicoccum (19,7\%), Nigrospora (17.2\%), Fusarium (7.1\%), Drechslera (2,4\%). Os gêneros Aspergillus, Chaetominum, Cladosporium, Cochliobolus, Phoma e Trichoderma foram detectados em menos de $1 \%$ dos grãos (Gráfico 1). Seus valores de Aa variaram entre 0.566 e 0.587 , e a Aa média foi de 0,581 .

Nossos resultados revelaram alta diversidade de fungos nas amostras analisadas, entretanto os gêneros Fusarium, Alternaria e Epicoccum se destacaram em todas as três localidades. Não foi encontrada correlação entre a atividade de água dos grãos com a frequência de fungos ou micotoxinas. Contudo, os valores 
encontrados estavam dentro dos parâmetros estabelecidos para evitar desenvolvimento fúngico durante o armazenamento e comercialização do trigo (RAHMAN, 2007).

Furlong et al. (1995a) analisando amostras recém-colhidas de trigo em SP encontraram perfil semelhante de fungos, com predominância dos gêneros Alternaria, Epicoccum e Drechslera. Tais resultados sinalizam uma população fúngica bem estabelecida na cultura de trigo. A micobiota isolada no presente trabalho também foi consistente com outros estudos sobre população fúngica em grãos de trigo no Brasil (BARBOSA, 2013), Argentina (BASÍLICO et al., 2010; ROIGE et al., 2009) e Tunísia (BENSASSI; MAHDI; HAJLAOUI, 2011)

Um dos gêneros predominantes, Alternaria, é um conhecido fungo de campo, com espécies produtoras de diversas fitotoxinas e responsáveis por perdas em plantações. Atualmente vem recebendo devida atenção pelo seu potencial toxigênico. Sabe-se que espécies como $A$. alternata e $A$. brassica, são capazes de produzir ácido tenuazônico (TA), alternariol $(\mathrm{AOH})$ e alternariol monometil éter (AME) (BOTALLICO; LOGRIECO, 1998). Pesquisadores alemães trabalhando com isolados de Alternaria de grãos de trigo observaram que $99 \%$ das linhagens produziram ao menos uma das três toxinas: TA, AOH e AME (PATRIARCA, AZCARATE, PINTO, 2007). Barbosa (2013) analisando $A O H$ em grãos de trigo beneficiados provenientes de São Paulo não encontrou níveis detectáveis nas amostras. Contudo, na presente investigação, a elevada frequência de isolados do gênero Alternaria indicam a necessidade de investigar mais profundamente as três principais toxinas produzidas por esse grupo nos grãos nacionais.

Outra contaminação significativa nas amostras foi de isolados do gênero Fusarium nos Estados do PR (39\%) e do RS (42,3\%). Em SP esta contaminação foi relativamente baixa (7.1\%). A alta frequência de Fusarium nas amostras do PR e RS pode ser atribuída aos elevados índices pluviométricos registrados nas citadas regiões durante o período de cultivo do trigo (CONAB, 2012). A predominância de Fusarium spp. em substratos com maior umidade foi constatada por diversos autores (LESLIE; SUMMERELL, 2006; NELSON et al., 1994. Já a baixa frequência encontrada nas amostras de SP pode estar relacionada com a elevada contaminação de isolados do gênero Microdochium. Essa elevada contaminação pode ser atribuída a um processo de antagonismo passivo envolvendo competição por espaço ou nutrientes no substrato (DEACON, 1980). 


\subsection{Gênero Microdochium}

Diante da elevada frequência, foram investigados ao nível de espécie, os isolados do gênero Microdochium. Inicialmente, foram empregados 0 sequenciamento parcial dos genes ITS1, ITS4, ITS5 e EF-1 para identificação, porém não houve sucesso. Desta forma, foi realizado PCR com iniciadores específicos desenvolvidos para as espécies $M$. nivale e $M$. majus, comumente encontradas em grãos trigos plantados em áreas frias como Europa e América do Norte (IOOS; BALHADJ; MENEZ, 2004, KOHL et al., 2007).

Todos os isolados estudados foram identificados como M. nivale (Figura 3). Ambas as espécies $M$. nivale e $M$. majus, em regiões com precipitação de neve, podem causar a doença "pinkmold" que acarreta sério prejuízo em plantações de trigo de inverno, como também em gramados. O fungo cresce e se desenvolve como um tapete rosado sobre as plantações em virtude de sua colônia de morfologia rosada e algodonosa (Figura 4). Em regiões de clima temperado os mesmos fungos são capazes de causar giberela assim como as espécies de Fusarium (TROSMO et al., 2001). Contudo, diferentemente de Fusarium esses fungos não são capazes de produzir micotoxinas.

Figura 3 - Identificação dos isolados de Microdochium nivale com iniciadores espécie-específicos para M. nivale e M. majus.

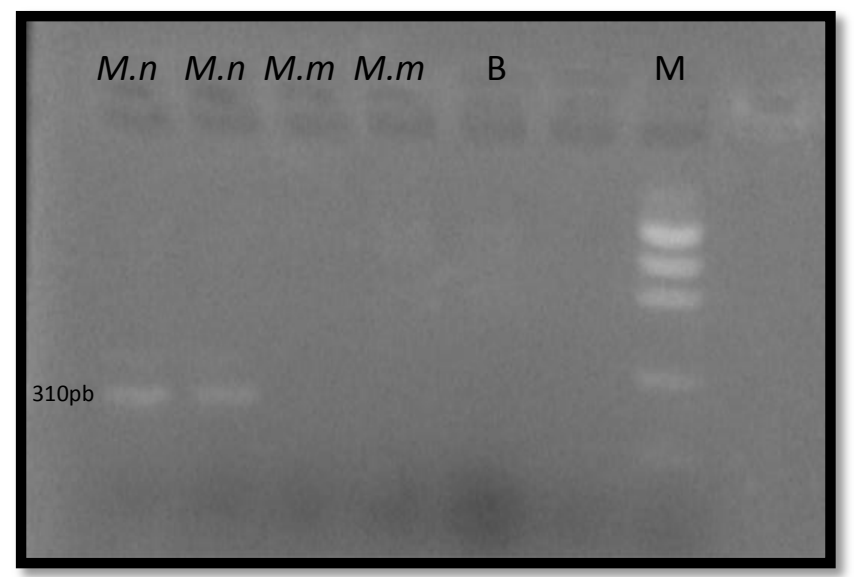

Nota: M.n - M. nivale; M.j - M. majus; B - Controle negativo; M- marcador 
Figura 4 - Morfologia da colônia de Microdochium nivale.

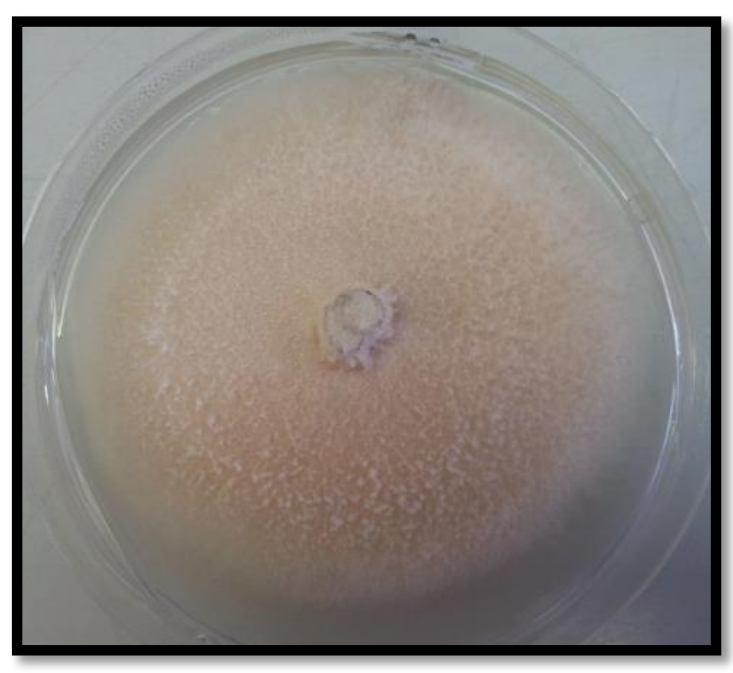

Nota: Colônia cultivada em meio BDA por 5 dias a $25^{\circ} \mathrm{C}$.

É importante destacar que este é o primeiro trabalho demonstrando a alta frequência da espécie $M$. nivale no trigo nacional. Em 1983, Diehl et al. isolaram $M$. nivale (anteriormente denominado Fusarium nivale var. nivale) em grãos de trigo coletados no RS porém citaram como sendo um patógeno de baixa relevância (DIEHL et al., 1983).

\subsection{Identificação dos isolados do gênero Fusarium}

Devido sua habilidade de causar sérias doenças em cereais e produzir diversas micotoxinas, os membros do gênero Fusarium foram identificados ao nível de espécie. Atualmente, 16 espécies estão incluídas no CEFG (AOKI et al., 2012) e destas, quatro foram isoladas e identificadas no trabalho: $F$. graminearum, $F$. meridionale, F. cortaderiae e F. austroamericanum. Esses resultados corroboram com O’Donnel et al. (2004) que relatou essas espécies como endêmicas da América do Sul, com exceção de F. graminearum s.s. que pode ser encontrado em diversas regiões do mundo.

Na figura 5 (A-D) é possível observar a morfologia das colônias das espécies identificadas. Inicialmente todos os isolados apresentaram micélio algodonoso raso de coloração bordo/rosada e verso coloração vinho. Porém ao longo do crescimento foram observadas variações na intensidade das cores, presença de micélio aéreo 
algodonoso de cor branca e desenvolvimento de micélio de cor amarelada. Essas variações não foram específicas por espécie, impossibilitando sua identificação por características morfológicas.

Para analisar as características dos macroconídeos de cada espécie, os isolados foram cultivados em meio SNA em luz branca para induzir a produção de esporos assexuais. Na figura $5(\mathrm{E}-\mathrm{H})$ através de microscopia óptica é possível observar diferenças sutis entre os esporos, como tamanho da estrutura e curvatura.

Os isolados de F. graminearum apresentaram macroconídeos mais curvados que as outras espécies (Fig. 5F). Entretanto também é possível observar estruturas curvadas tanto em $F$. meridionale e $F$. cortaderiae (Fig. 5E, G). A espécie $F$. austroamericanum apresentou esporos tipicamente retos (Fig. 5H). Essas características corroboram com a descrição de AOKI et al., (2012) das espécies analisadas. O comprimento dos esporos variou bastante, em geral $F$. austroamericanum e F. meridionale apresentaram estruturas maiores como também conídeos mais septados. 
Figura 5 - Morfologia dos membros do Complexo de espécie Fusarium graminearum.

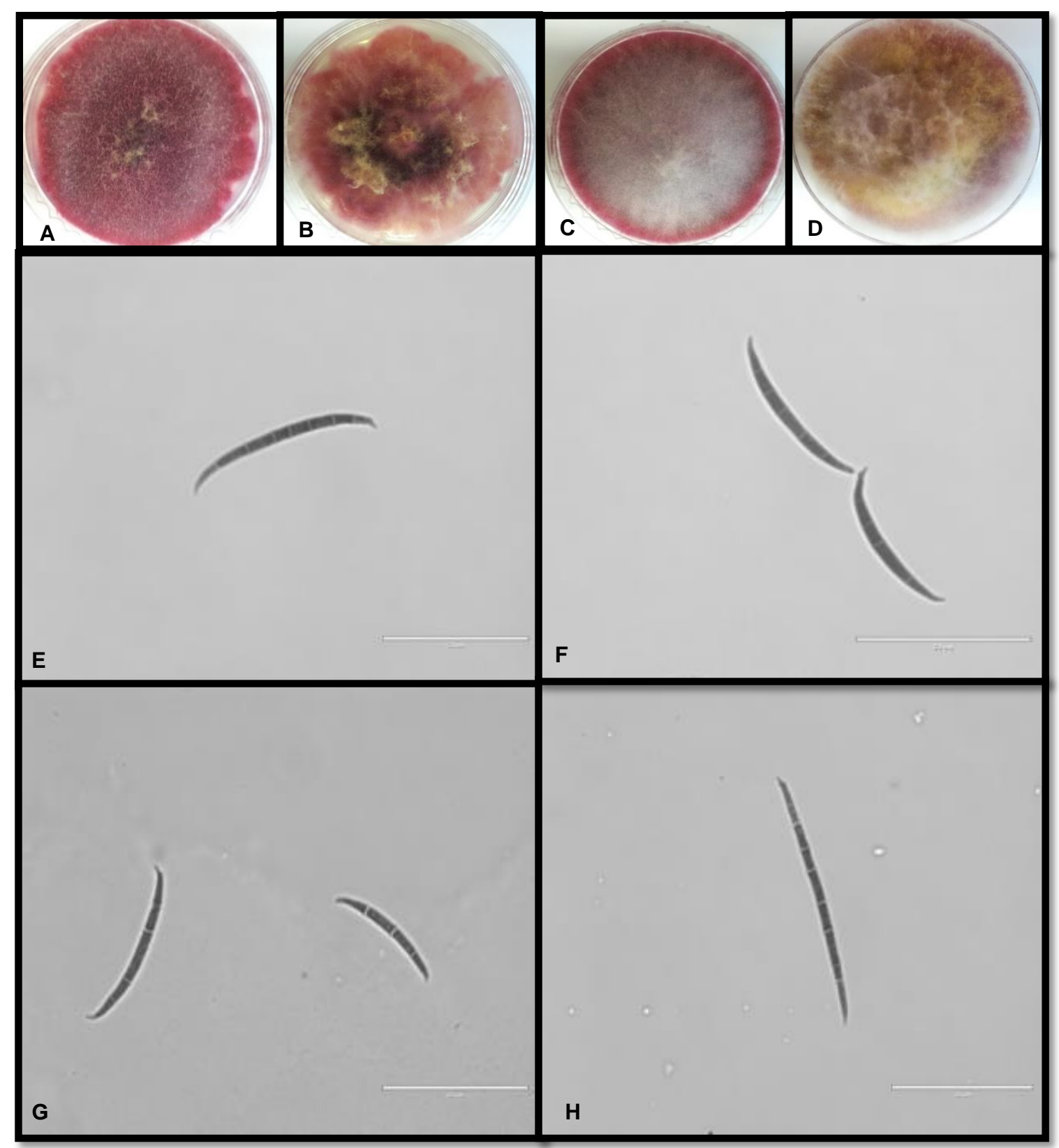

Nota: F. meridionale (A, E), F. graminearum s.s (B, F), F. austroamericanum (C, G) e $F$. cortaderiae $(D, H)$ cultivados em meio BDA e SNA, respectivamente incubados a $25^{\circ} \mathrm{C}$ por cinco dias. Estruturas de E-H estão com aumento de 600X.

A distribuição das espécies isoladas variou entre as regiões. Porém, de maneira geral as espécies F. meridionale e $F$. graminearum s.s foram predominantes nas três regiões estudadas. Os isolados $F$. meridionale foram mais 
frequentes em SP (56\%) e RS (47\%) enquanto F. graminearum s.s foi o membro do CEFG mais predominante no PR (54\%) (Tabela 1).

Tabela 1 - Frequência dos membros do Complexo de espécie Fusarium graminearum isolados de grãos de trigo provenientes dos Estados de São Paulo, Paraná e Rio Grande do Sul.

\begin{tabular}{llll}
\hline $\begin{array}{l}\text { Região } \\
\text { Espécies do CEFG }\end{array}$ & PR & RS & SP \\
$(\%)$ & & & \\
\hline F. graminearum s.s & 54 & 25 & 34 \\
F. meridionale & 36 & 47 & 56 \\
F. cortaderiae & 8 & 25 & 6 \\
F. austroamericanum & 2 & 3 & 4 \\
\hline
\end{tabular}

Esse é o primeiro estudo demonstrando alta frequência de $F$. meridionale no trigo brasileiro. Estudos anteriores relataram frequência muito maior de $F$. graminearum s.s (ASTOLFI et al., 2012; DEL PONTE et al., 2015; SCOZ et al., 2009). Esses resultados divergentes podem ser explicados em parte pela diferença na seleção de grãos. Os estudos citados utilizaram espigas danificadas e com sintomas de giberela enquanto 0 presente estudo trabalhou com grãos aparentemente saudáveis. O uso exclusivo de espigas gibereladas pode levar a uma seleção de espécies mais agressivas e adaptadas. Diferenças em produção de esporos, velocidade de crescimento e agressividade entre membros do CEFG já foram relatadas (SPOLTI et al., 2012; TÓTH et al., 2008).

\subsection{Identificação dos genótipos de tricotecenos tipo B dos isolados do Complexo de espécie de F. graminearum}

Embora os isolados do CEFG exibam alta semelhança morfológica, seus membros podem produzir variados tipos de micotoxinas. Sabe-se que $F$. graminearum s.s é capaz de produzir DON, seus derivados acetilados (3-ADON e 15-ADON), como também NIV. A espécie $F$. meridionale, limita-se a produção de 
NIV. Já $F$. austroamericanum e F. cortaderiae são capazes de produzir tanto NIV quanto o derivado 3-ADON (AOKI et al., 2012).

Um total de 100 isolados foi analisado pela técnica de PCR para a identificação de seus perfis de produção de tricotecenos (genótipo). No gráfico 2 é possível observar a frequência do genótipo de cada espécie isolada. As cepas de $F$. graminearum s.s foram predominantemente 15-ADON (95,5\%), seguido por NIV (3\%) e 3-ADON (1,5\%). Já $100 \%$ das cepas de F. meridionale apresentaram genótipo NIV. Os isolados pertencentes a espécie $F$. cortaderiae foram caracterizados como 3-ADON (14. 3\%), mas na sua maioria identificados como NIV (85.7\%). Já F. austroamericanum obteve $50 \%$ dos isolados $3-A D O N$ e o restante genótipo NIV.

\section{Gráfico 2 - Frequência dos genótipos encontrados nas diferentes espécies do Complexo de espécie F. graminearum}

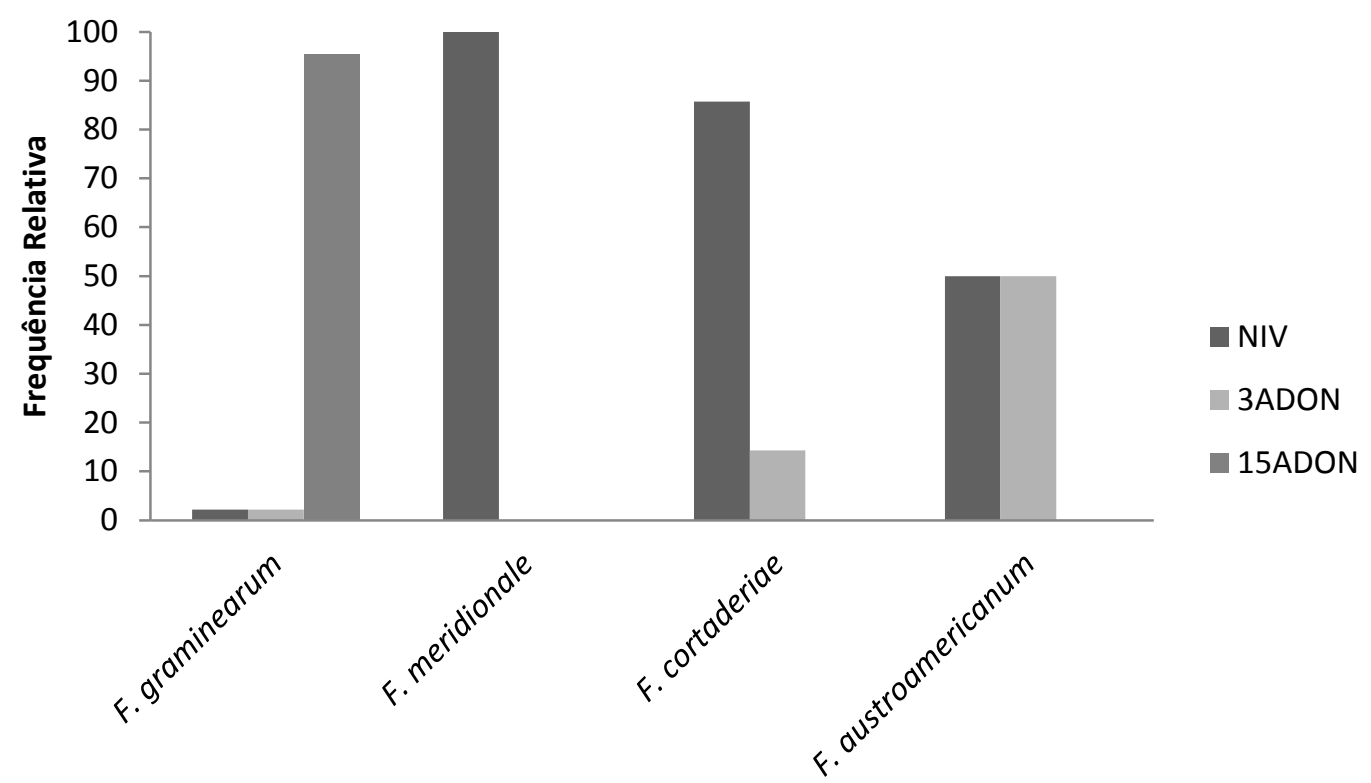

O perfil de genótipo também diferiu de acordo com os Estados analisados (Gráfico 3). Os isolados provenientes de grãos de trigo colhidos no Estado do Paraná foram identificados principalmente como 15-ADON (59\%) seguido por NIV (35.8\%) e 3-ADON (5.2\%). Já os isolados de São Paulo e Rio Grande do Sul 
apresentaram perfis semelhante sendo o genótipo mais frequente NIV (61.2 e 67 . $8 \%$ ) seguido por 15-ADON (32.3 e 32. $2 \%$ ). O genótipo 3-ADON foi identificado no Estado de São Paulo (6.5\%) em baixa frequência e ausente no Rio Grande do Sul.

\section{Gráfico 3 - Frequência dos genótipos dos isolados provenientes dos Estados do Rio Grande do Sul, Paraná e São Paulo.}

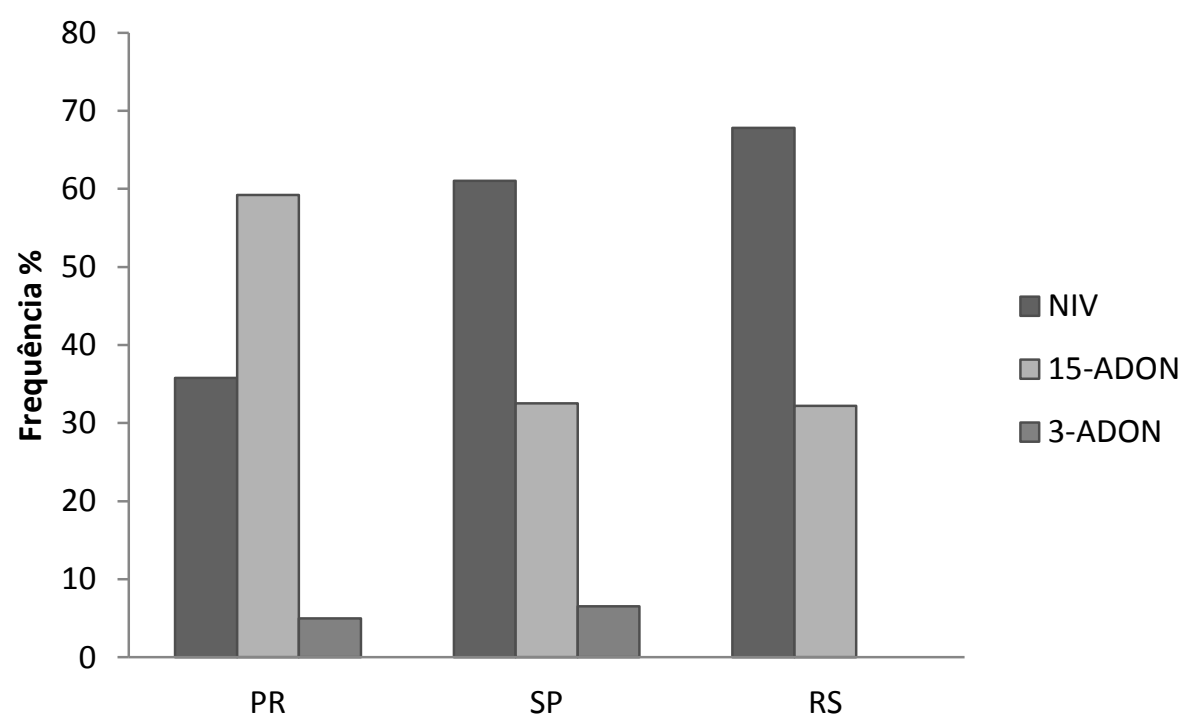

$\mathrm{Na}$ América do Sul encontramos diferentes perfis genotípicos. Pan et al. (2013) realizando um estudo em trigo no Uruguai, demonstraram que a maioria dos isolados são 15-ADON com baixa ocorrência de NIV. Já na Argentina, pesquisadores encontraram em sua grande maioria genótipo NIV, seguido por 15ADON e 3- DON (SAMPIETRO et al., 2012).

Nossos resultados mostram predominância do genótipo NIV nos Estados de SP e RS e perfil 15-ADON no PR, contudo a alta frequência de NIV e 15-ADON e baixa expressividade de 3-ADON foi comum a todas as regiões. No Brasil, estudos anteriores relataram perfis com predomínio de 15-ADON, presença mediana de NIV e ausência ou frequências abaixo de $1 \%$ de isolados 3-ADON (ASTOFOLI et al., 2012; DEL PONTE et al., 2015; SCOZ et al., 2009). É importante destacar que nossos os resultados foram divergentes com estudos anteriores, pois os genótipos encontrados estão diretamente correlacionados com as duas espécies mais isoladas no trabalho: F. meridionale e F. graminearum s.s. Afinal, a vasta maioria 
dos isolados de $F$. graminearum s.s foram determinados como produtores de 15ADON e indivíduos $F$. meridionale apresentam exclusivamente genótipo NIV.

É essencial avaliar os perfis genotípicos de tricotecenos. Além de indicar potenciais micotoxinas produzidas nos cereais, a técnica permite também investigar possíveis mudanças de perfis. Os isolados fúngicos encontrados na América do Norte tem sofrido uma alteração gradual de perfil toxigênico durante as últimas décadas. A ocorrência de isolados de genótipo 3-ADON tem aumentado significantemente e substituindo os isolados 15-ADON, genótipo anteriormente predominante, em plantações de trigo (SCHMALE et al., 2011; WARD, et al., 2008). Puri e Zhong (2010) relataram que fungos de genótipo 3-ADON são mais agressivos e produzem maiores níveis de DON, o que explicaria a mudança. Em estudo similar, Zhang et al. (2012) também observaram maior acúmulo de tricotecenos, de produção conidial e de resistência a antifúngicos em isolados $F$. asiaticum com perfil 3-ADON que com perfil NIV. Entretanto, Spolti et al. (2012) não encontraram diferenças significativas em agressividade, produção de tricotecenos e poder de infecção no trigo entre os genótipos 3-ADON e 15-ADON. As razões para a contínua alteração de perfis ainda não está bem esclarecida.

\subsection{Identificação dos genótipos de tricotecenos tipo B em grãos de trigo}

A identificação dos genótipos nos grão de trigo permitiu analisar a frequência de cada genótipo, mas também quantificar essa frequência utilizando a concentração de DNA dos isolados de acordo com seu genótipo. O uso dessa técnica foi inédito no Brasil e possibilitou analisar o perfil genotípico de maneira mais robusta e sensível que a técnica de isolamento das cepas e identificação do genótipo por PCR convencional (ver item 5.4).

Nossos resultados mostraram que $100 \%$ dos grãos analisados apresentaram isolados com genótipo 15-ADON. A frequência dos perfis NIV e 3-ADON variaram de acordo com a região (Tabela 2). Em São Paulo, NIV esteve presente em 68\% das amostras e 3-ADON somente $12 \%$. No Paraná foram detectados isolados NIV em $72 \%$ das amostras e isolados $3-A D O N$ em $36 \%$. No Estado do RS, foram encontradas as maiores frequências, $100 \%$ para NIV e $52 \%$ para $3-A D O N$. Diferentemente da PCR convencional, a QPCR permite quantificar de maneira 
confiável a concentração de DNA dos isolados, permitindo avaliar a relevância de cada genótipo encontrado.

Tabela 2 - Frequência de genótipo de tricotecenos em grãos de trigo provenientes dos Estados de São Paulo, Paraná e Rio Grande do Sul.

\begin{tabular}{llll}
\hline \multirow{4}{*}{ Estado } & \multicolumn{3}{l}{ Frequência \% } \\
\cline { 2 - 4 } & 15-ADON & 3-ADON & NIV \\
\hline SP & 100 & 12 & 68 \\
RS & 100 & 52 & 100 \\
PR & 100 & 36 & 72 \\
\hline
\end{tabular}

Gráfico 4 - Proporção média da concentração de DNA de fungos produtores de tricotecenos em grãos de trigo provenientes dos Estados de São Paulo, Paraná e Rio Grande do Sul.

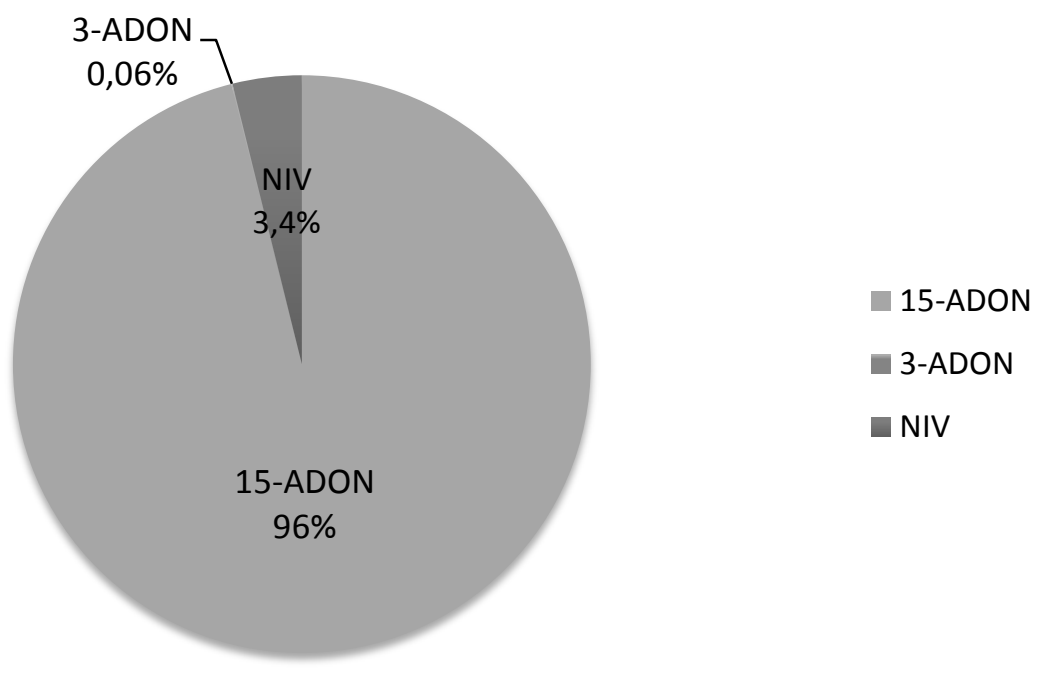

Além de estar presente em todos os grãos analisados, a concentração média de DNA pertencente ao genótipo 15-ADON foi muito maior que os outros genótipos. De todo DNA fúngico quantificado, 96\% foi atribuído ao genótipo 15-ADON, 3,4\% ao NIV e somente 0.06\% ao genótipo 3-ADON (Gráfico 4). No gráfico 5 estão destacados as concentrações médias de cada isolado por região estudada. Novamente ficam evidentes que as maiores concentrações de DNA pertencem aos 
isolados 15-ADON (graf. 5A). Nivalenol mesmo frequente obteve uma concentração muito menor que 15-ADON, principalmente em SP e PR (graf. 5B). Já o genótipo 3$A D O N$, com baixa frequência em geral, não apresentou concentrações relevantes de DNA (graf. 5C).

Gráfico 5 - Concentração média de DNA de fungos produtores de tricotecenos em grãos de trigo dos Estados de São Paulo, Paraná e Rio Grande do Sul.

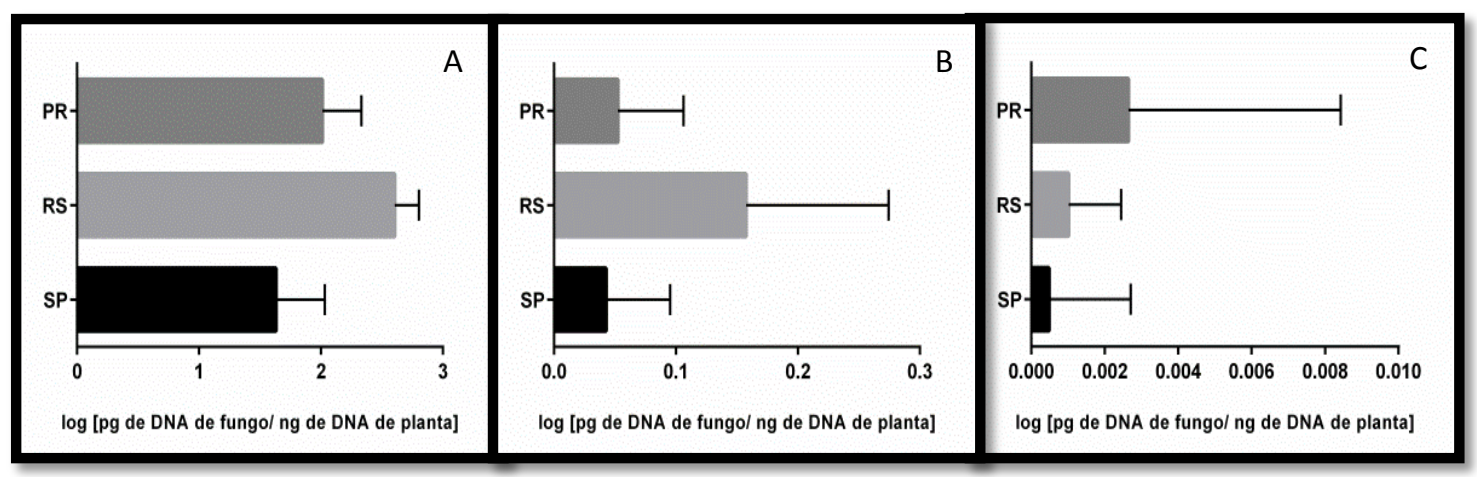

Nota: A: 15-ADON; B: NIV; C: 3-ADON. Barras - desvio padrão. Concentração de pg de DNA de fungo/ ng de DNA de planta.

Todos os produtores de 15-ADON e 3-ADON também produzem DON. No gráfico 6 é possível perceber uma tendência de correlação positiva entre produção de DON nos grãos e a concentração de DNA dos genótipos 15ADON+3-ADON. Para avaliar essa tendência, foi utilizado o rank de Spearman, onde o valor 0 é considerado sem correlação entre as variáveis e os valores de -1 ou $1,100 \%$ de correlação negativa ou positiva, respectivamente. 
Gráfico 6 - Concentração de desoxinivalenol e de DNA dos isolados fúngicos (15ADON+3-ADON) em grãos de trigo provenientes dos Estados de São Paulo, Paraná e Rio Grande do Sul.

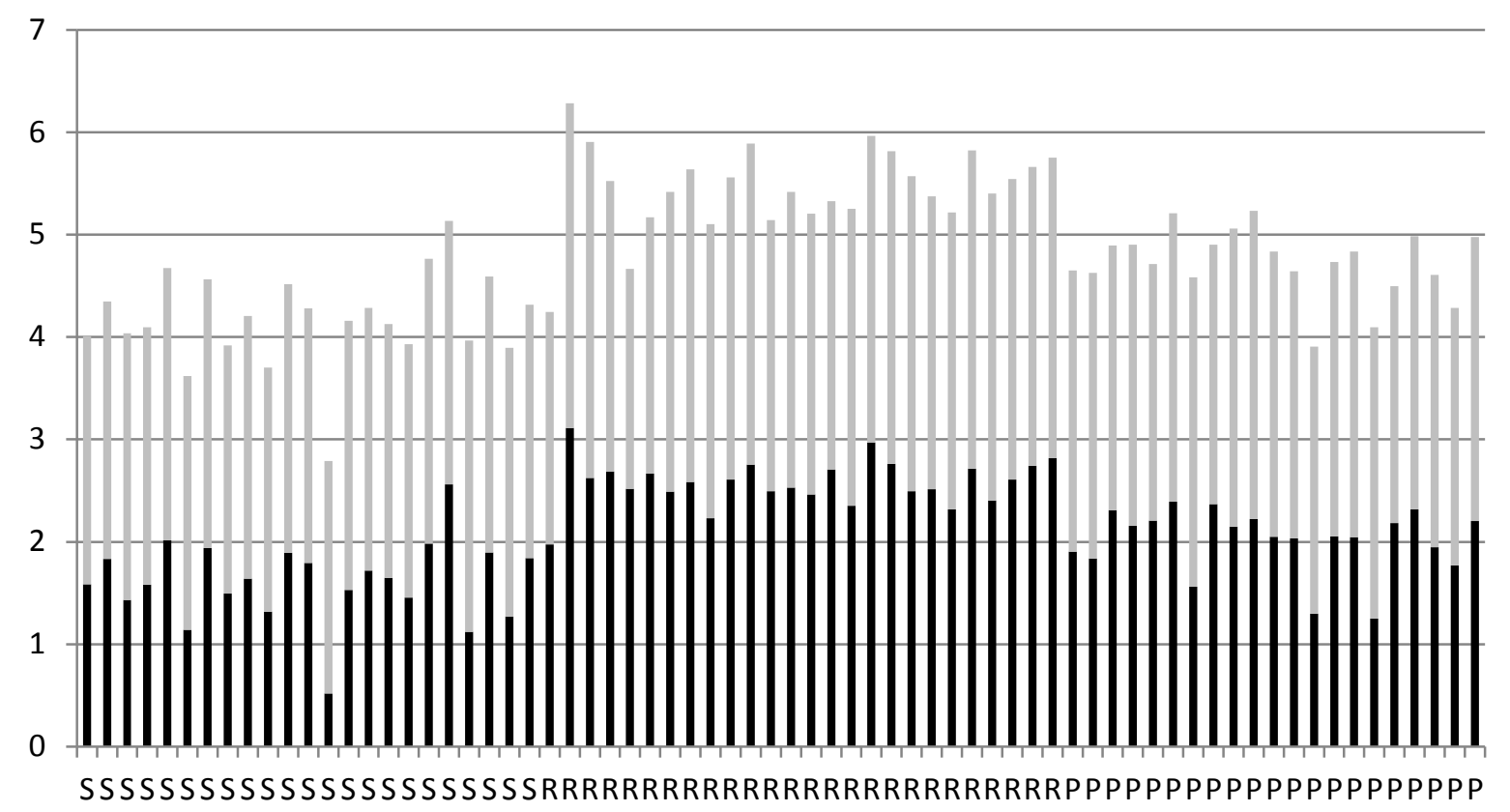

Nota: Barras cinzas- log [DON $\mu \mathrm{g} / \mathrm{kg}$ ]; Barras pretas - log [pg de DNA de fungo/ ng de DNA de planta]; S- São Paulo; R - Rio Grande do Sul; P- Paraná.

Foi encontrado correlação de $0.58(p<0,001)$ entre a concentração de DNA dos genótipos (15-ADON + 3-ADON) e a quantidade de DON nos grãos (Gráfico 7), demonstrando a correlação positiva da carga fúngica dos genótipos e a produção de DON presente nos grãos. É importante destacar que a correlação foi testada com a soma de DNA de 15-ADON e 3-ADON como também com a concentração de 15ADON sozinha, e em ambos a correlação obteve o mesmo rank $\left(r_{\mathrm{s}}-0.58\right)$ indicando que mesmo presente em algumas amostras, os isolados de genótipo 3-ADON não foram relevantes na produção de DON nos grãos de trigo analisados. 
Gráfico 7 - Correlação entre produção de desoxinivalenol e concentração de DNA dos isolados (15ADON+3-ADON) em grãos de trigo.

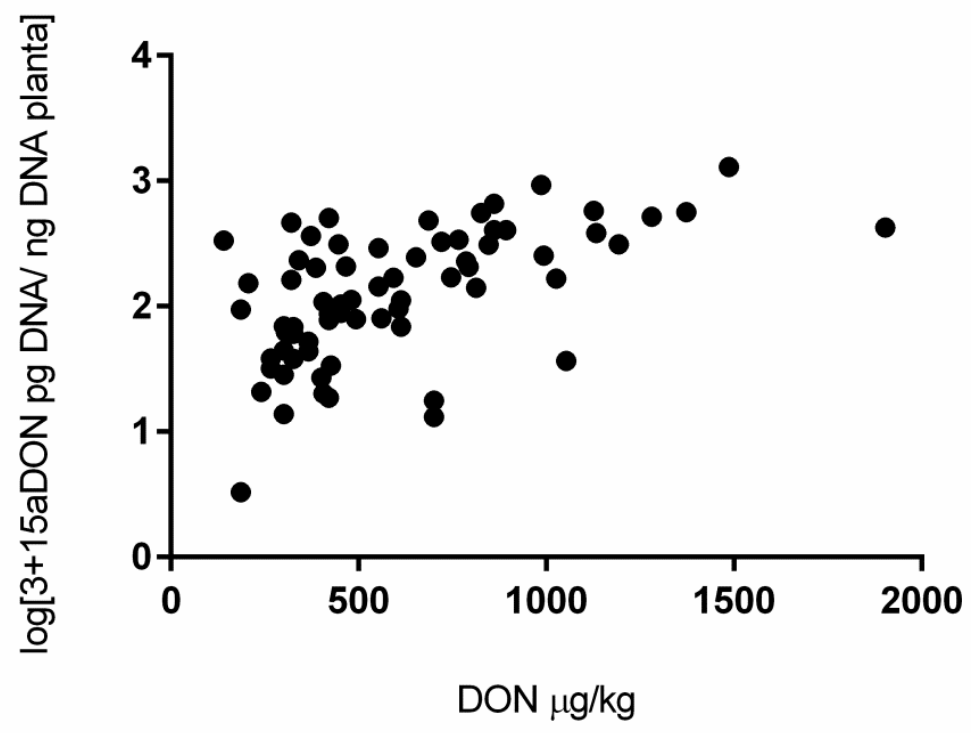

Nilsen et al. (2012) encontraram boa correlação entre genótipo 15-ADON e DON e entre genótipo NIV de $F$. graminearum e produção de nivalenol. Outro estudo encontrou boa correlação $(r=0.82)$ relacionando a biomassa de $F$. graminearum através do gene TRI6 e a produção de DON em grãos artificialmente contaminados (HOREVAJ; MILUS; BLUHM, 2011).

\subsection{Comparação entre a detecção dos genótipos dos isolados e a dos genótipos em grãos de trigo}

Dois métodos foram utilizados para avaliar o perfil genotípico dos isolados: PCR convencional identificando os genótipos dos fungos isolados (ver item 5.4) e qPCR (ver item 5.4) identificando os genótipos do DNA fúngico dentro do grão de trigo. Em ambos foram encontrados tanto semelhanças quanto incongruências.

Ambas as técnicas demonstraram que 3-ADON não é um genótipo frequente ou relevante no trigo nacional. Sua frequência foi maior por qPCR porém a quantificação de DNA demonstrou que a quantidade de isolados é muito pequena para influenciar a produção de DON.

Já os perfis 15-ADON e NIV apresentaram resultados um pouco contraditórios entre as duas técnicas. A frequência de 15-ADON e NIV por PCR 
convencional não está de acordo com o que foi encontrado por qPCR. A técnica de qPCR demonstrou que 15-ADON foi predominante em todas as amostras, que apresenta maior quantidade de DNA que os outros genótipos e esta diretamente correlacionado com a produção de DON. Já nivalenol, mesmo presente em todas as amostras do RS e na maioria de SP e PR, exibiu concentrações muito abaixo dos isolados de 15-ADON.

A PCR convencional não é capaz de quantificar a concentração de cada genótipo, mas era esperado que a frequência de isolamento seguisse um caminho proporcional a concentração encontrada por qPCR. Contudo, os resultados obtidos a partir da PCR convencional exibiram maior frequência de NIV que 15-DON em SP e RS, dados inversos aos obtidos por qPCR nos grãos de trigo.

Para explicar essa discrepância algumas hipóteses foram levantadas. No caso das espécies analisadas (PCR convencional), o genótipo encontrado está fortemente relacionado com a espécie isolada. Isso porque quase todos os isolados F. graminearum s.s são 15-ADON e todos os isolados $F$. meridionale são NIV. Além disso, F. cortaderiae em sua maioria também são genótipo NIV. Então é possível concluir que a alta proporção de genótipo NIV encontrado por PCR convencional ocorreu principalmente porque houve elevado número de $F$. meridionale isolados do trigo.

Partindo desse princípio, o principal questionamento é: porque foram isolados tantos F. meridionale quando a concentração fúngica dentro do grão foi principalmente de F. graminearum s.s (genótipo 15-ADON)?

Inicialmente foi cogitado que fora isolado um número insuficiente de isolados ( $n=150$ ) o que poderia acarretar em um falso resultado. Entretanto a alta frequência de NIV ocorreu nas três regiões (SP, PR e RS) sendo que cada isolamento ocorreu em épocas diferentes. Assim, parece improvável a ocorrência de erro amostral em três momentos diferentes de isolamento. Também a possibilidade de ter sido realizado um isolamento seletivo não parece provável, pois como já foi descrito, os membros do CEFG são extremamente semelhantes e seleção por aspectos morfológicos seria inviável. Foi também cogitado a possibilidade de identificação molecular incorreta, contudo essa hipótese também foi descartada, pois EF-1a é um gene bem definido para identificação do gênero Fusarium e parâmetros para garantir uma identificação confiável foram tomados (sequenciamento da fita 
"forward" e "reverse", confirmação com dois bancos de dados diferentes - National Center for Biotechnology Information (NCBI) e FusariumID, entre outros).

Mesmo com níveis de concentração de DNA menores que 15-ADON, o genótipo NIV apresentou elevada frequência nos grãos de trigo (Tabela 2) dessa forma, um elevado isolamento de F. meridionale não poderia ser descartado, a questão é porque ele se desenvolveu melhor que isolados 15-ADON, que apresentaram uma carga fúngica muito maior?

Como citado anteriormente (ver item 5.3), o uso de grãos sadios frente a grãos giberelados, pode ter colaborado com a alta frequência de $F$. meridionale isolados. Outro fator que pode ter contribuído é a mudança de substrato (saída da planta para meio de cultura). Estudos já demonstraram que F. graminearum s.s apresenta um comportamento mais agressivo dentro da planta que F. meridionale, sinalizando ser mais adaptado para a infecção e sintomas de giberela (GOSWAMI; KISTLER, 2005; SPOLTI et al., 2012). Contudo, o isolamento dos grãos em meio de cultura, onde a umidade e temperatura são controladas, pode ter diminuído a vantagem dos isolados de F. graminearum s.s, e dado oportunidade para $F$. meridionale emergir e ser selecionado.

Contudo a causa para essa diferença permanece desconhecida, sujeita somente a hipóteses. Futuramente seria interessante avaliar a concentração de carga fúngica dos isolados em grãos giberelados e sadios por qPCR como também investigar a capacidade de germinação e desenvolvimento frente a diferentes meios de cultura, umidade e temperatura das espécies $F$. meridionale e F. graminearum S.S..

\subsection{Expressão dos genes envolvidos na via biossintética de tricotecenos}

\subsubsection{Validação do método}

Para a validação do método $\Delta \Delta$ Ct foram realizados ensaios de curva padrão para avaliar a eficiência (E) de amplificação dos iniciadores dos genes alvos e de referência. Todos os genes apresentaram eficiência dentro dos parâmetros estabelecidos, entre 90-110\% (Apêndice A). Também foi realizada em todos os ensaios, a análise do ponto de "melting". Essa análise indica a temperatura que o 
DNA se encontra $50 \%$ dissociado. Dessa forma é possível observar se a amplificação é especifica (somente um pico) ou se existe amplificações inespecíficas (mais de um pico) ocasionadas pela formação de "primer-dimer", entre outros. Os resultados podem ser observados no apêndice B.

\subsubsection{Resultados}

Diante da recente divisão da espécie F. graminearum em um Complexo de espécie filogenético, grande parte dos estudos focam apenas na espécie filogenética $F$. graminearum s.s e raramente abordam outros membros do complexo. Por isso tivemos como objetivo comparar a expressão gênica de quatro espécies F. graminearum sensu stricto, F. meridionale, F. cortaderiae e F. austroamericanum - e investigar o comportamento gênico entre as espécies como também pesquisar possíveis correlações gênicas.

Para fins comparativos separamos as análises em grupos biológicos de acordo com a espécie. A metodologia escolhida $(\Delta \Delta \mathrm{Ct})$ é estritamente comparativa e requer um grupo calibrador que será base para todas as comparações. Para este estudo foi escolhido o grupo $F$. austroamericanum.

Nossos resultados revelaram que os genes diferiram de acordo com a espécie estudada (grupo biológico) como também de acordo com o comportamento de outros genes. As maiores diferenças de níveis de expressão relativa foram TRI5 e TRI12. O gene TRI5, que codifica a proteína precursora de tricoteceno, foi o gene menos expresso nos isolados da espécie de $F$. graminearum s.s. Já os grupos $F$. meridionale e F. cortaderiae obtiveram maior expressão comparado ao grupo calibrador ( $F$. austroamericanum). O gene TRI12, com função de bomba de efluxo dos metabólitos, foi o mais expresso nos três grupos, em média 1.4 vezes mais que F. austroamericanum (Gráfico 8). Esses resultados indicaram que os genes TRI5 e TRI12 foram afetados principalmente de acordo com a espécie analisada. 
Gráfico 8 - Expressão relativa dos genes TRI4, TRI5, TRI6, TRI12 E TRI101 dos grupos biológicos F. graminearum s.s, F. meridionale, F. cortaderiae e F. austroamericanum.

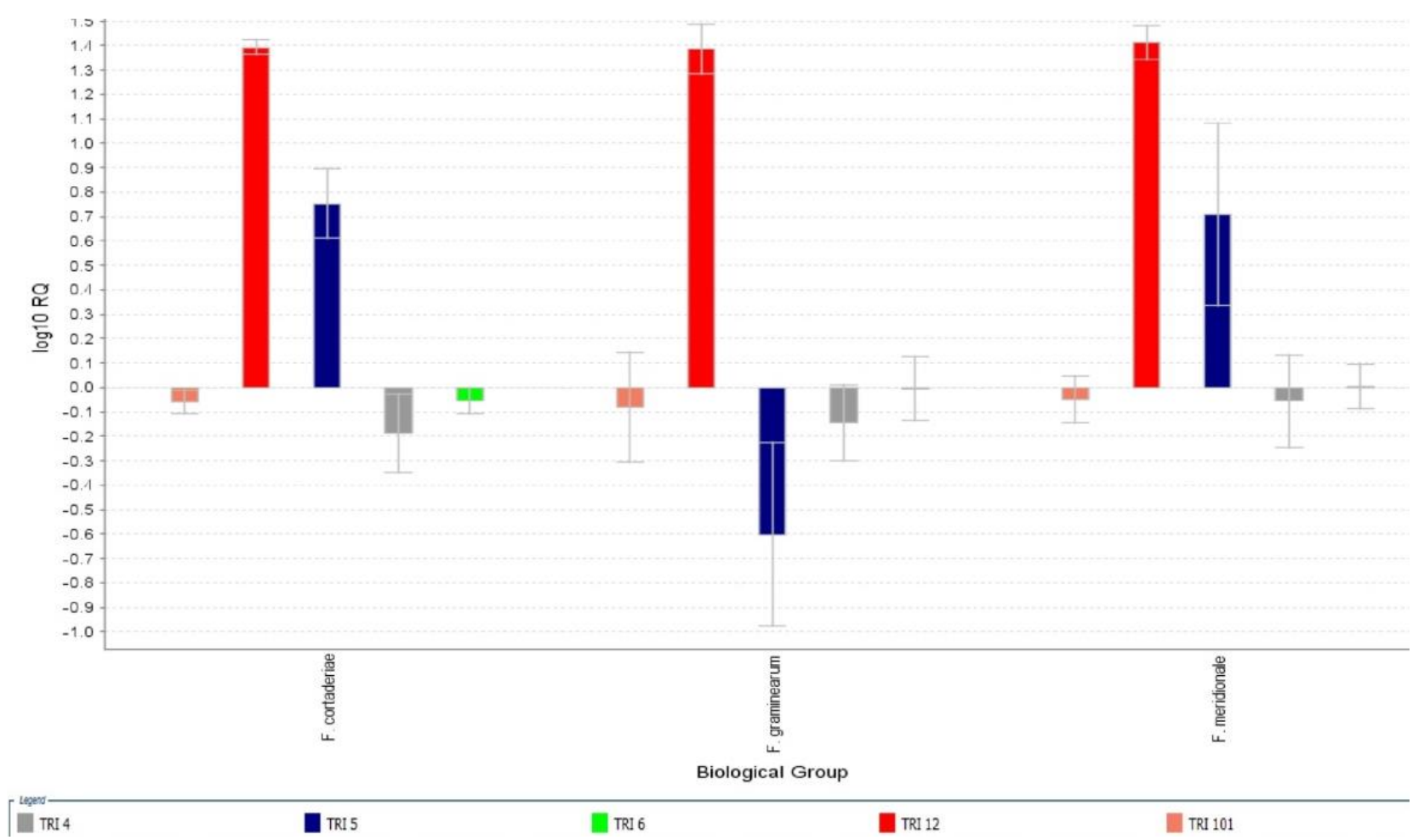

Nota: Grupo F. austroamericanum é o calibrador assim não aparece no gráfico.

Comparativamente aos isolados da espécie $F$. austroamericanum, os genes TRI6, TRI101 e TRI4 foram menos expressos nos outros três grupos, porém as variações encontradas não foram elevadas (Gráfico 8). Já os genes TRI4, TRI6 e TRI101 parecem apresentar comportamento diferente. No gráfico 9 é possível observar que estes genes possuem uma correlação positiva entre si na maioria das cepas estudadas.

Essa correlação esta possivelmente relacionada com o comportamento de TRI6. O gene TRI6 codifica um fator de transcrição dedo de zinco e é considerado o maior regulador da via biossintética (PROCTOR et al., 1995). Os genes TRI6 e TRI101 estão em diferentes clusters e cromossomos (KIMURA et al., 1998) porém juntamente com outros genes, TRI101 e TRI4 possuem dentro de sua região promotora uma sequência de ligação do fator de transcrição codificado por TRI6 (YNAGGCC) (HOHN, et al., 1999). Essa sequência permite que o fator de TRI6 atue em diferentes genes e cromossomos, corroborando com nossos resultados. 
Gráfico 9 - Expressão relativa dos genes TRI6, TRI101 e TRI4 dos isolados do Complexo de espécie Fusarium graminearum.

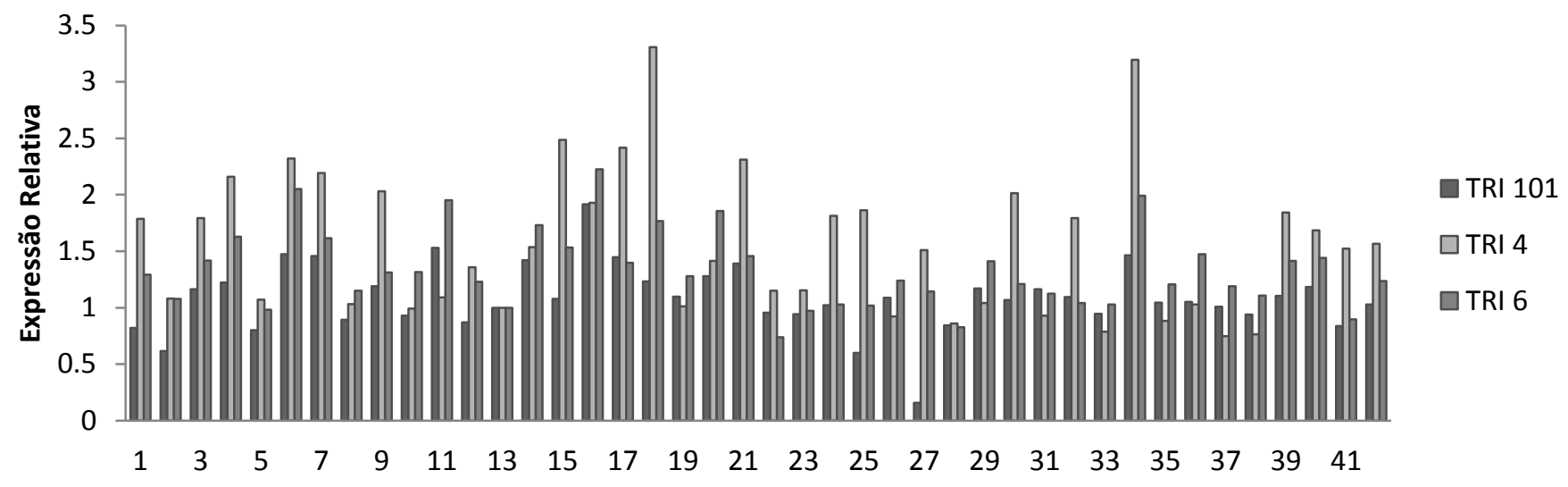

O estudo de expressão gênica das diferentes espécies demonstrou que parte dos genes (TRI6, TRI4 e TRI101) possui comportamento similar nas quatro espécies analisadas, indicando serem ideais para estudos futuros envolvendo membros do CEFG em diferentes tratamentos.

\subsection{Detecção e quantificação de desoxinivalenol em grãos de trigo}

As análises por UPLC confirmaram a presença de DON e ZEA nas amostras de trigo estudadas. Contaminação por DON foi predominante e observada em 100\% das amostras. Entretanto os níveis de DON diferiram significantemente $(p<0,05)$ entre as regiões variando entre 126 a $5.393 \mu \mathrm{g} / \mathrm{kg}$. As concentrações medianas foram de 323, 466 e $783 \mu \mathrm{g} / \mathrm{kg}$ em SP, PR e RS, respectivamente (Tabela 3). 
Tabela 3 - Determinação de desoxinivalenol em grãos de trigo naturalmente contaminado provenientes dos Estados de São Paulo, Paraná e Rio Grande do Sul.

\begin{tabular}{lccc}
\hline & \multicolumn{3}{c}{ DON } \\
\cline { 3 - 5 } & Estado & $\begin{array}{c}\text { Amostras positivas } \\
(\%)\end{array}$ & $\begin{array}{c}\text { Concentração } \\
(\mu \mathrm{g} / \mathbf{k g})\end{array}$ \\
\cline { 4 - 5 } & & $280-1513$ & 466 \\
\cline { 3 - 5 } SR & 100 & $126-606$ & 323 \\
RS & 100 & $140-5393$ & 783
\end{tabular}

Limite de deteç̧ão: $16.7 \mu \mathrm{g} / \mathrm{kg}$.

Empregando o LMT da ANVISA de 2017 (Quadro 1) de grãos préprocessados, todas as amostras estariam dentro do LMT estipulado (acima de 3000 $\mu \mathrm{g} / \mathrm{kg}$ ) exceto uma pertencente ao Estado do RS que revelou nível de $5393 \mu \mathrm{g} / \mathrm{kg}$ de DON. A mediana nas amostras do RS foi de $783 \mu \mathrm{g} / \mathrm{kg}$, porém 11 amostras obtiveram níveis acima de $1000 \mu \mathrm{g} / \mathrm{kg}$. Já nos outros Estados a maioria das amostras apresentaram níveis inferiores a $750 \mu \mathrm{g} / \mathrm{kg}$ de DON (Tabela 4). Embora apenas uma amostra tenha detectado nível acima do LMT $(3000 \mu \mathrm{g} / \mathrm{kg})$ permitido pela ANVISA, o grau de contaminação (100\%) é um forte indicativo de futuros prejuízos que DON pode causar na agricultura brasileira. 
Tabela 4 - Concentrações de desoxinivalenol encontradas nos grãos de trigo provenientes dos Estados de São Paulo, Paraná e Rio Grande do Sul.

\begin{tabular}{cc}
$\begin{array}{c}\text { Níveis } \\
(\mu \mathbf{g} / \mathbf{k g})\end{array}$ & no de amostras \\
\hline Paraná & DON \\
$>3000$ & 0 \\
$>1000$ & 4 \\
$>750$ & 1 \\
Rio Grande do Sul & \\
$>3000$ & 1 \\
$>1000$ & 11 \\
$>750$ & 16 \\
& \\
São Paulo & \\
$>3000$ & 0 \\
$>1000$ & 0 \\
$>750$ & 0 \\
\hline
\end{tabular}

Os primeiros estudos envolvendo DON no trigo nacional realizados por Sabino et al. (1989) e Furlong et al. (1995a, b) relataram baixa incidência da toxina (1-20\%), porém, com médias similares às detectadas no presente trabalho. Estudo realizado por Calori-Dominguez et al. (2007) avaliando a contaminação por DON no trigo nacional e uruguaio revelou a presença da toxina em $94 \%$ das amostras nacionais, com média de $332 \mu \mathrm{g} / \mathrm{kg}$. Em 2012, Del Ponte, Garda-Buffon e Furlong (2012) pesquisando a ocorrência de DON em três safras consecutivas de trigo no Estado do RS, detectaram a toxina em aproximadamente, 99\% de espigas de trigo gibereladas, frequência esta, similar a nossa investigação. Estudo analisando a ocorrência de DON no Estado do PR, empregando o ensaio imunoenzimático (ELISA) detectou níveis médios de $1.894 \mu \mathrm{g} / \mathrm{kg}$ e frequência de $64,4 \%$ (SANTOS et al., 2013). Barbosa (2013) trabalhando com amostras oriundas de São Paulo, obteve média de $1255 \mu \mathrm{g} / \mathrm{kg}$ de DON em trigo recém-colhido.

Apesar dos poucos estudos realizados no Brasil, constata-se um aumento significativo na frequência de DON ao longo dos anos no trigo brasileiro, coincidindo com os achados em outros países da América do Sul (GONZÁLES et al., 2008; PAN; GRANERI; BETTUCI, 2009). Esses resultados corroboram a ideia que mesmo não sendo o tricoteceno mais tóxico, a elevada frequência faz de DON um das toxinas mais relevantes na atualidade. 


\subsection{Detecção e quantificação de zearalenona em grãos de trigo}

ZEA, uma toxina estrogênica e recentemente incluída na legislação brasileira, (ANVISA, 2011) foi detectada nos três Estados estudados, porém sua incidência variou significantemente $(p<0,001)$ entre as regiões.

A tabela 5 sumariza as concentrações de ZEA encontradas nos grãos. A frequência de amostras positivas para ZEA foram de $100 \%, 80 \%$ e $48 \%$ no RS, PR e SP, respectivamente.

\section{Tabela 5 - Determinação de zearalenona em grãos de trigo naturalmente contaminado provenientes dos Estados de São Paulo, Paraná e Rio Grande do} Sul.

\begin{tabular}{lccc}
\hline Estado & \multicolumn{3}{c}{ ZEA } \\
& $\begin{array}{c}\text { Amostras } \\
\text { positivas }\end{array}$ & \multicolumn{2}{c}{$\begin{array}{c}\text { Concentração } \\
(\boldsymbol{\mu g} / \mathbf{k g})\end{array}$} \\
\cline { 3 - 4 } & $(\%)$ & Variação & Mediana \\
\hline PR & 80 & nd-260 & 100 \\
SP & 48 & nd-93 & 14 \\
RS & 100 & $133-2706$ & 843
\end{tabular}

Limite de detecção: $1.3 \mu \mathrm{g} / \mathrm{kg}$; nd: abaixo do limite de detecção.

Segundo regulamentações definidas pela ANVISA, a partir de 2017, grãos de trigo pré-processados não podem ultrapassar $400 \mathrm{ug} / \mathrm{kg}$ de ZEA (quadro 1). Em SP, apenas uma amostra apresentou contaminação de ZEA acima de $400 \mathrm{ug} / \mathrm{kg}$. Já no $\mathrm{PR}$, nenhuma amostra estava acima do LMT, entretanto três amostras estavam acima de $200 \mathrm{ug} / \mathrm{kg}$ e 24 acima de $100 \mathrm{ug} / \mathrm{kg}$. Os níveis de ZEA detectados no Estado do RS foram os mais elevados, $82 \%$ das amostras exibiram níveis superiores a $400 \mathrm{ug} / \mathrm{kg}$ (Tabela 6). A concentração mediana encontrada nas amostras provenientes do RS $(843 \mathrm{ug} / \mathrm{kg})$ foi cerca de oito vezes maior que às outras regiões, o dobro do valor permitido pela ANVISA (400 ug/kg). 
Tabela 6 - Concentrações de zearalenona encontradas nos grãos de trigo provenientes dos Estados de São Paulo, Paraná e Rio Grande do Sul.

\begin{tabular}{cc}
\hline $\begin{array}{c}\text { Níveis } \\
(\boldsymbol{\mu g} / \mathbf{k g})\end{array}$ & $\begin{array}{c}\mathbf{n} \text { - de } \\
\text { amostras }\end{array}$ \\
\hline Paraná & ZEA \\
$>400$ & 0 \\
$>200$ & 3 \\
$>100$ & 24 \\
Rio Grande do Sul & \\
$>400$ & 41 \\
$>200$ & 6 \\
$>100$ & 3 \\
São Paulo & \\
$>400$ & 1 \\
$>200$ & 0 \\
$>100$ & 0 \\
\hline
\end{tabular}

Visando um possível mercado externo e aplicando como referência o LMT da União Europeia (EC, 2006), onde o máximo permitido para grãos pré-processados é de $100 \mu \mathrm{g} / \mathrm{kg}$, todas as amostras do Estado do RS e 54\% das amostras do PR estariam acima do LMT estipulado. A concentração mediana de ZEA encontrada nos grãos do RS $(843 \mu \mathrm{g} / \mathrm{kg})$ seria aproximadamente oito vezes o LMT pela União Europeia para grãos de trigo (EC, 2006).

A literatura sobre ZEA no trigo nacional é ainda muito escassa. Estudos realizados no Estado de São Paulo, por Furlong et al. (1995a, b) e Barbosa (2013) detectaram ZEA em 15 e 4\% das amostras analisadas, respectivamente. Outras pesquisas destacaram a presença de ZEA em arroz e milho (ALMEIDA et al., 2012; POZZl et al., 1995).

É relevante apontar que tanto as concentrações de DON quanto de ZEA foram maiores no RS, seguido por PR e SP. Esse fato não pode ser descartado e parece estar intimamente ligado a micobiota das regiões. O gráfico 10 demonstra a relação de contaminação pelos membros do CEFG e os níveis de DON e ZEA encontrados nos grãos de trigo. O Estado do RS, afetado pela maior quantidade de fungos, indicado pela concentração de DNA do CEFG, também foi o mais abundante na presença de toxinas. Já SP, onde a contaminação pelo gênero 
Fusarium foi menor, a contaminação de DON e ZEA nos grãos também foi mais branda.

Gráfico 10 - Comparação entre as médias de produção de desoxinivalenol, zearalenona e as médias da concentração de DNA fúngico dos genótipos de tricotecenos nos Estados de São Paulo, Paraná e Rio Grande do Sul.

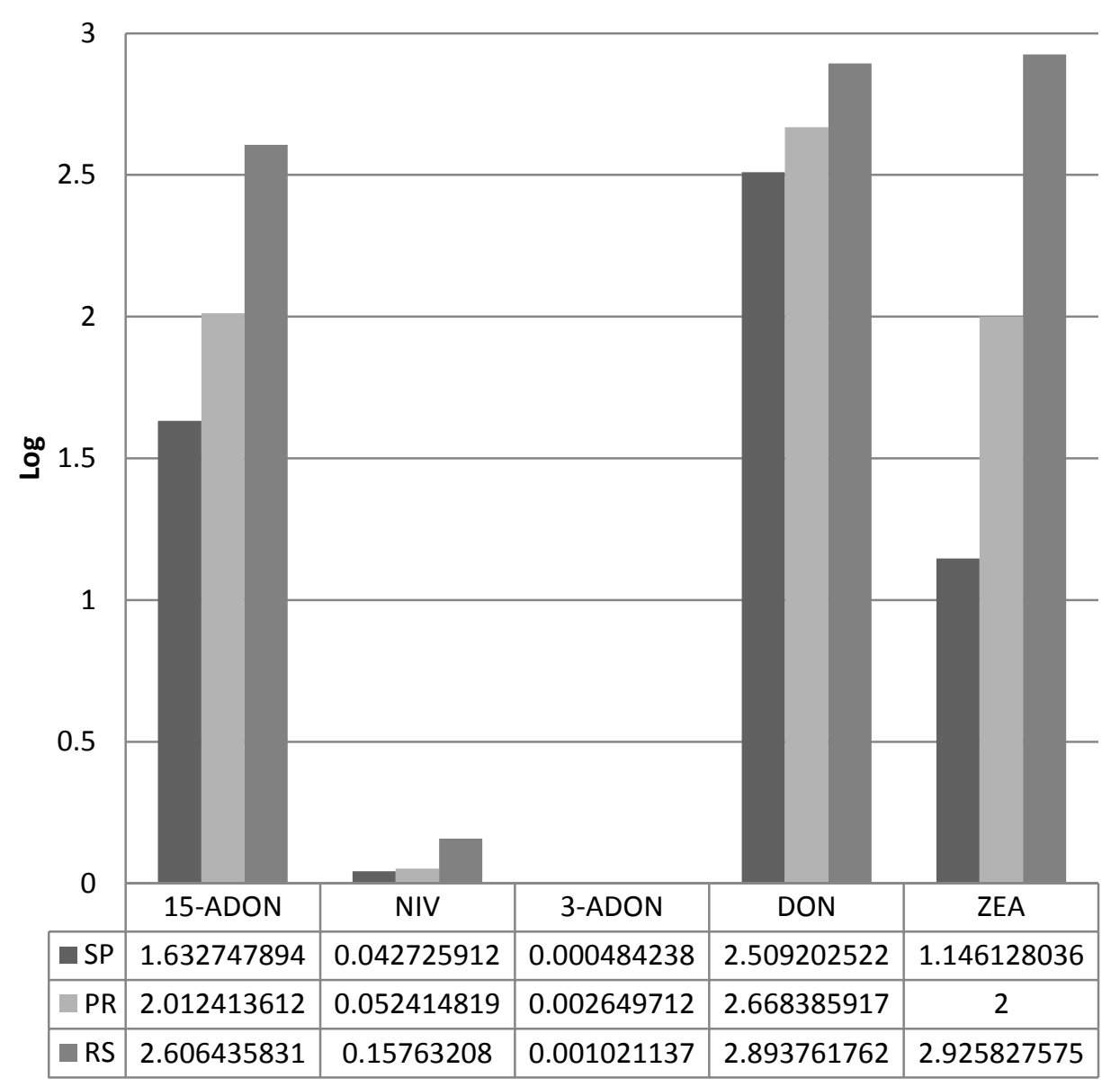

Nota: As concentrações de DNA estão em pg de fungo/ng de planta. As concentrações das toxinas estão em $\mu \mathrm{g} / \mathrm{kg}$. Todos valores foram transformados para log.

Como citado anteriormente (ver item 5.1) os registros de precipitação excessiva nos Estados do RS e PR possivelmente facilitaram o maior desenvolvimento dos isolados do CEFG nessas plantações. Também, a forte presença de $M$. nivale em SP e menor frequência de CEFG, indica uma competição entre os dois fungos, compatível com a baixa produção de toxinas encontrada na região. Esses dados demonstram claramente a relação da frequência da micobiota toxigênica com a contaminação de toxinas nos grãos. 


\subsection{Co-ocorrência de DON e ZEA}

Nos últimos anos tem se estudado efeitos sinergéticos e/ou aditivos entre duas ou mais micotoxinas. A co-ocorrência de DON e ZEA nos grãos foram de $42 \%$, $80 \%$ e $100 \%$ nos Estados de SP, PR e RS, respectivamente (Gráfico 11).

Gráfico 11 - Porcentagem de co-ocorrência de DON e ZEA nos grãos de trigo provenientes dos Estados de São Paulo, Paraná e Rio Grande do Sul.

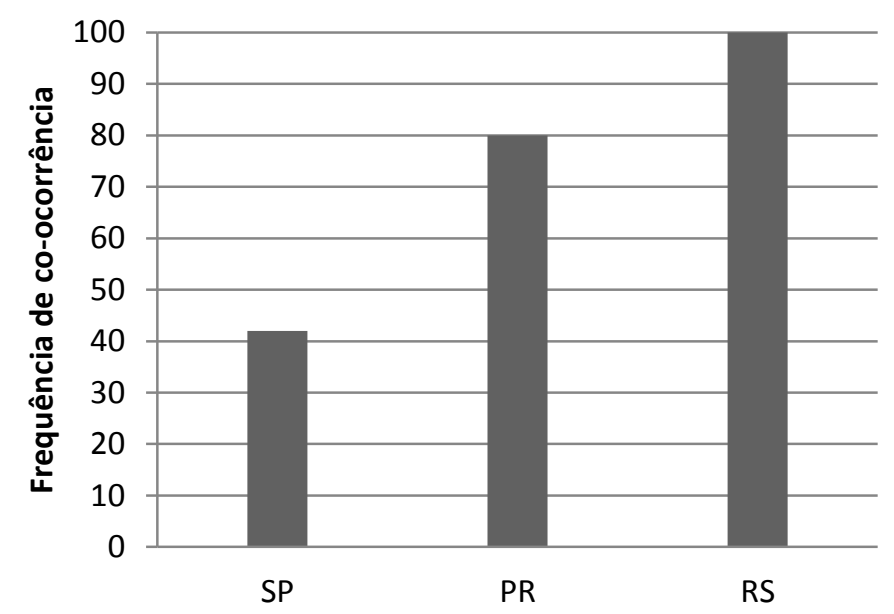

Segundo Kouadio et al. (2007) trabalhando com células epiteliais intestinais humanas Caco-2, a mistura binária ZEA/DON causa efeitos sinergéticos nocivos na viabilidade celular e na síntese de DNA. Aumento de citotoxicidade entre as misturas de NIV/DON e NIV/ZEA também foram relatadas por Tajima et al. (2002) em células de fibroblastos.

Os efeitos da co-ocorrência de micotoxinas é também dependente das doses adotadas. Pesquisas realizadas por Alassane-Kapembi et al. (2013) também utilizando linhagem Caco-2, relataram efeitos sinérgicos em baixas doses da mistura ternária DON/3-ADON/15-ADON, contudo em altas doses, a mesma mistura provocou efeitos aditivos.

Estudos in vivo ainda são escassos, porém já foram relatados casos de disfunção no baço (TIEMANN, et al., 2006) como também de degeneração de ovócitos de porcos (ALM et al., 2005) após ingestão de ração contendo altas concentrações de DON e ZEA. 


\section{CONCLUSÃO}

O estudo polifásico da micobiota presente nos grãos de trigo como sua produção de toxinas realizados neste trabalho agregaram novas e importantes informações sobre o trigo no Brasil:

- O estudo da micobiota confirmou o predomínio dos gêneros Alternaria, Fusarium e Epicoccum, perfil que já foi descrito em trabalhos anteriores, indicando uma população bem estabelecida no trigo nacional;

- A elevada frequência da espécie não toxigênica Microdochium nivale, embora causadora de giberela, nas amostras do Estado de São Paulo foi inédita no trigo brasileiro;

- O complexo de espécie Fusarium graminearum (CEFG) foi dominante no isolamento do gênero Fusarium, e quatro membros foram identificados: $F$. graminearum s.s, F. meridionale, F. cortaderiae e F. austroamericanum;

- Os membros do CEFG mais relevantes foram $F$. meridionale e $F$. graminearum s.s nas três regiões estudadas;

- Os genótipos do isolados foram em sua maioria NIV para as espécies $F$. meridionale, $F$. cortaderiae e $F$. austroamericanum e 15-ADON para $F$. graminearum s.s

- O perfil genotípico em grãos de trigo demonstrou que o genótipo 15-ADON esteve presente em 100\% das amostras. Já NIV em $80 \%$ e 3-ADON em somente $33,3 \%$ das amostras.

- A quantificação de DNA dos isolados de acordo com seu genótipo por qPCR demostrou que 15-ADON contribuiu em aproximadamente $96 \%$ de todo DNA quantificado, seguido por NIV com $3.84 \%$ e $3-A D O N$, com somente $0.06 \%$, indicando que 3-ADON não é um perfil relevante e que $15-A D O N$, é o principal genótipo nos grãos de trigo nacional.

- Houve discordância entre as frequências de genótipo dos isolados e o genótipo diretamente dos grãos e acredita-se a mudança de substrato pode ter influenciado a seleção de isolamento;

- Foi encontrada correlação positiva entre a concentração de DNA dos isolados 15-ADON com a produção de DON, outro indicativo do papel desses isolados no perfil toxigênico dos grãos; 
- Os resultados de expressão gênica indicaram que há genes da via biossintética de tricotecenos que apresentam comportamento de acordo com a espécie filogenética analisada (TRI5 e TRI12) e genes que não são influenciados pela espécie, mas pelo comportamento de outros genes (TRI4, TRI6 e TRI101);

- A toxina desoxinivalenol (DON) foi detectada em todas as amostras analisadas, embora apenas uma do Estado do RS estava com níveis acima do permitido;

- Considerando o LMT de ZEA estipulado pela ANVISA para grãos préprocessados, a vigorar a partir de $2017,82 \%$ das amostras do RS estariam acima do limite permitido de $400 \mathrm{ug} / \mathrm{kg}$;

- Os dados de contaminação pelo CEFG através de qPCR e as concentrações de DON e ZEA encontradas demonstram claramente correlação entre níveis de contaminação fúngica e de toxinas;

- A co-ocorrência de DON e ZEA no trigo nacional foi de $100 \%$, $80 \%$ e $42 \%$ nos Estados do Rio Grande do Sul, Paraná e São Paulo. 


\section{REFERÊNCIAS*}

ABID-ESSEFI, S. et al. DNA fragmentation, apoptosis and cell cycle arrest induced by zearalenone in cultured DOK, Vero and Caco-2 cells: prevention by Vitamin E. Toxicology, v. 192, p. 237-248, 2003..

AGÊNCIA NACIONAL DE VIGILÂNCIA SANITÁRIA (ANVISA) 2011. Disponível em: $<\mathrm{http}: / /$ portal.anvisa.gov.br/wps/wcm/connect/10269e8043ec6fc2af60ef6b7f09096f/r dc0007_18_02_2011.pdf?MOD=AJPERES>. Acesso em: 2 mar. 2015.

AGÊNCIA NACIONAL DE VIGILÂNCIA SANITÁRIA (ANVISA) 2013. Disponível em: $<$ http://www.sgc.goias.gov.br/upload/arquivos/2014-01/diario-oficial---rdc-59.pdf>. Acesso em: 12 mar. 2015

ALASSANE-KPEMBI, I. et al. New insights into mycotoxin mixtures: The toxicity of low doses of Type B trichothecenes on intestinal epithelial cells is synergistic. Toxicol. Appl. Pharmacol., v. 727, p. 191-198, 2013.

ALEXANDER, N. J. et al. Expression of Tri15 in Fusarium sporotrichioides. Curr. Genet., v. 45, p. 157-162, 2004.

ALEXANDER, N. J.; MCCORMICK, S. P.; HOHN, T. M. TRI12, a trichothecene efflux pump from Fusarium sporotrichioides: gene isolation and expression in yeast. Mol. Gen. Genet., v. 261, p. 977-984, 1999.

ALM, $\mathrm{H}$. et al. Influence of Fusarium-toxin contaminated feed on initial quality and meiotic competence of gilt oocytes. Reprod. Toxicol., v. 22, p. 44-50, 2006.

ALMEIDA, $M$. et al. Co-occurrence of aflatoxins $B_{1}, B_{2}, G_{1}$ and $G_{2}$, ochratoxin $A$, zearalenone, deoxynivalenol, and citreoviridin in rice in Brazil. Food Addit. Contam. Part A, v. 29, p. 694-703, 2012.

ALVAREZ, C. L; AZCARATE, M.P; PINTO, V.F. Toxigenic potential of Fusarium graminearum sensu stricto isolates from wheat in Argentina. Intr. J. Food Microbiol., v. 135, p. 131-135, 2009.

AOKI, T. et al. Systematics, phylogeny and trichothecene mycotoxin potential of Fusarium head blight cereal pathogens. Mycotoxins, v. 62, p. 91-102, 2012.

*De acordo com:

ASSOCIAÇÃO BRASILEIRA DE NORMAS TÉCNICAS. NBR 6023: informação e documentação: referências: elaboração. Rio de Janeiro, 2002. 
AOKI, T.; O'DONNEL, K. Morphological and molecular characterization of Fusarium pseudograminearum sp. nov., formerly recognized as the group 1 population of $F$. graminearum. Mycologia, v. 91, p. 597-609, 1999.

ASTOLFI, P. et al. Genetic population structure and trichothecene genotypes of Fusarium graminearum isolated from wheat in southern Brazil. Plant Pathol., v. 61, p. 289-295, 2012.

AZCONA O. J. et al. Induction of cytokine mRNAs in mice after oral exposure to the trichoth- ecene vomitoxin (deoxynivalenol): relationship to toxin distribu- tion and protein synthesis inhibition. Toxicol. Appl. Pharmacol., v. 133, p. 109-120, 1995.

BAI, G. SHANER, G. Scab of wheat: prospects for control. Plant Dis., v. 78, p. 760766, 1994.

BAINOTTI, C. et al. Genetic Resistance to Fusarium Head Blight in Wheat (Triticum aestivum L.). In: MAGLIANO, T. M. A.; CHULZE, S. N. Fusarium Head Blight in Latin America, Holanda: Springer, 2013, p. 231-240.

BARBA J.T.; REIS E. M.; FORCELINI, C. A. Efeito da temperatura e de fungicida na transmissão de Bipolaris sorokiniana da semente para plântulas de cevada. Fitopatol. Bras., v.27, p. 500-507, 2002.

BARBOSA B.C. Micoflora e ocorrência de micotoxinas em grãos de trigo recém-colhidos e armazenados. 2013, 140 f. Dissertação (Mestrado em Microbiologia), Instituto de Ciências Biomédicas - Universidade de São Paulo, 2013.

BARNETT, A. M. et al. The interactions between endogenous bacteria, dietary components and the mucus layer of the large bowel. Food Funct., v. 3, p. 690-699, 2012.

BASÍLICO, M. L. Z. et al. Fungal diversity and natural occurrence of fusaproliferin, beauvericin, deoxynivalenol and nivalenol in wheat cultivated in Santa Fe Province, Argentina. Mycotoxin Res., v. 26, 85-91, 2010.

BAYRAM O. et al. VelB/VeA/LaeA complex coordinates light signal with fungal development and secondary metabolism. Science, v. 320, p. 1504-1506, 2008.

BELHASSEN, $\mathrm{H}$. et al. Zearalenone and its metabolites in urine and breast cancer risk: A case-control study in Tunisia. Chemosphere, v. 128, p. 1-6, 2015.

BENSASSI, F. et al. Survey of the mycobiota of freshly harvested wheat grains in the main production areas of Tunisia. Afr. J. Food Sci., v. 5, p. 292-298, 2011. 
BERJAK, P. Report of seed storage committee working group on the effects of storage fungi on seed viability. 1980-1983. Seed Sci. Technol., v. 12, p. 233-253, 1984.

BONY, S.; CARCELEN, M.; DEVAX, A. Genotoxicity assesment of deoxynivalenol in Caco-2 cell line model using the Comet assay. Toxicol. Lett., v. 166, p. 67-76, 2006.

BOTTALICO, A.; LOGRIECO, A. Toxigenic Alternaria species from economic importance. In Micotoxins in Agriculture and Food Safety. New York: Ed. Dekker, 1998, p. 65- 107.

BROWN, D. W.; PROCTOR, R. A. Fusarium: genomics, molecular and cellular biology. Caister: Academic Press, 2013, 194 p.

CANADIAN FOOD INSPECTION AGENCY (CFIA) 2012. Disponível em: $<$ http://www.inspection.gc.ca/animals/feeds/regulatory-guidance/rg-

8/eng/1347383943203/1347384015909?chap=1\#s1c1 > Acesso em: 2 fev. 2015.

CASA, R. T. et al. Danos causados pela infecção de Gibberella zeae em trigo. Fitopatol. Bras., v. 29, p. 289-293, 2004.

COUNCIL FOR AGRICULTURAL SCIENCE AND TECHNOLOGY (CAST). Mycotoxins: risks in plant, animal and human systems. Ames, lowa: Task Force Report, n. 139, 2003, 199 p.

CHAMPEIL, A.; DORÉ, T.; FOURBET, J. F. Fusarium head blight: epidemiological origin of the effects of cultural practices on head blight attacks and the production of of mycotoxins by Fusarium in wheat grains. Plant Sci., v. 166, p. 1389-1415, 2004 ..

CHANDLER, E. A.;SIMPSON, D. R.; NILCHOLSON, T. P. Development of PCR assays to Tri7 and Tri13 trichothecene biosynthetic genes, and characterisation of chemotypes of Fusarium graminearum, Fusarium culmorum and Fusarium cerealis. Physiol. Mol. Plant. Pathol., v. 62, p. 355-367, 2003.

CHOW, J. et al. Host-bacterial symbiosis in health and disease. Adv. Immunol., v. 107, p. 243-274, 2010.

COLDHAM, N.G. et al. Evaluation of a recombinant yeast cell estrogen screening assay. Environ. Health Perspect., v. 105, p. 734- 742, 1997.

COLLINS, T.F.X. et al. Effects of deoxynivalenol (DON, vomitoxin) on in utero development in rats. Food Chem. Toxicol., v. 44.6, p. 747-757, 2006. 
COMPANHIA DE ABASTECIMENTO (CONAB). 2015. Grãos Safras. Disponível em:

<http://www.conab.gov.br/OlalaCMS/uploads/arquivos/15_03_11_14_07_48_boletim _graos_marco_2015.pdf>. Acesso em: 10 mar. 2015.

COMPANHIA NACIONAL DE ABASTECIMENTO (CONAB) 2012. Grãos Safra 2012/2013.

Disponível

em:

http://www.conab.gov.br/OlalaCMS/uploads/arquivos/12_11_08_09_10_48_boletim_ portugues_novembro_2012.pdf Acesso em: 20 mar. 2015.

DÄNICKE, S.; VALENTA, H.; DÖLL, S. On the toxicokinetics and the metabolism of deoxynivalenol (DON) in the pig. Arch. Anim. Nutr., v. 58, p. 169-180, 2004.

DEACON, J. W. Introduction to modern mycology. London, Blackwell Scientific Publication, 1980, $197 \mathrm{p}$.

DEL PONTE, E. et al. Regional and field-specific factors affect the composition of Fusarium head blight pathogens in subtropical no-till wheat agroecosystem of Brazil. Phytopathology, v. 105, p. 246-254, 2015.

DEL PONTE, E. M.; GARDA-BUFFON, J.; FURLONG, E. B. Deoxynivalenol and nivalenol in commercial wheat grain related to Fusarium head blight epidemics in southern Brazil. Food Chem., v. 132, p.1087-1091, 2012.

DESJARDINS, A. E.; PROCTOR, R. H. Molecular biology of Fusarium mycotoxins Int J Food Microbiol., v. 119, p. 47-50, 2007.

DESJARDINS, A. E. From yellow rain to green wheat: 25 years of trichothecene biosynthesis research. J. Agric. Food Chem., v. 57, p. 4478-84, 2009.

DESJARDINS, A. E. Fusarium Mycotoxins: Chemistry, Genetics, and Biology. St. Paul, MN: APS Press, 2006, 260 p.

DIEHL J. A.; KOCHHANN, R. A.; TINLINE, R. D. Sistemas de cultivo sobre podridão comum de raízes e mal-do-pé do trigo. Pes. Agrop. Bras., v. 18, p. 235-341, 1983.

DILL-MACKY, R.; JONES, R. K. The Effect of Previous Crop Residues and Tillage on Fusarium Head Blight of Wheat. Plant Dis., v. 84, p. 71-76, 2000.

EMPRESA BRASILEIRA DE PESQUISA AGROPECUÁRIA (EMBRAPA). 2002. Boletim de pesquisa e desenvolvimento n. 11. Disponível em: <http://www.cnpt.embrapa.br/biblio/p_bp11.htm>. Acesso em: 4 fev. 2015. 
EMPRESA BRASILEIRA DE PESQUISA AGROPECUÁRIA (EMBRAPA). 2014. Nota técnica. Disponível em: <https://www.embrapa.br/busca-de-noticias//noticia/2157564/nota-tecnica-doencas-do-trigo---safra-2014>. Acesso em 12 mar. 2015.

ERIKSEN, G. S. et al. Transformation of trichothecenes in ileal digesta and faeces from pigs. Arch. Tierernahr., v. 56, p. 263-274, 2002.

ERIKSEN, G. S.; PETTERSSON, H.; LINDBERG, J. E. Absorption, metabolism and excretion of 3-acetyl DON in pigs. Arch. Tierernahr., v. 57, p. 335-345, 2003.

ETZEL, R. A., et al. Acute pulmonary hemorrhage in infants associated with exposure to Stachybotrys atra and other fungi. Arch. Pediatr. \& Adolesc. Med., v. 152, p. 757-762, 1998.

EUROPEAN COMISSION (EC) 2006. Maximum levels for certain contaminants in foodstuffs. Disponível em: <http://eurlex.europa.eu/LexUriServ/LexUriServ.do?uri=CONSLEG:2006R1881:20100701:EN: PDF>. Acesso em: 10 mar. 2015

EUROPEAN FOOD SAFETY AUTHORITY (EFSA). Deoxynivalenol in food and feed: occurrence and exposure. EFSA Journal, v. 11, 2013, 56 p.

FOOD AND AGRICULTURE ORGANIZATION OF THE UNITED NATIONS (FAO) 2000.

$<$ http://faostat.fao.org/site/567/DesktopDefault.aspx?PagelD=567\#ancor>. Acesso em: 12 mar. 2015.

FRANCIS R. G.; BURGESS L. W. Characteristics of two populations of Fusarium roseum 'Graminearum' in eastern Australia. Trans. Br. Mycol. Soc., v. 68, p. 421427, 1977.

FRANKIC, T.; SALOBIR, J.; REZAR, V. The effect of vitamin E supplementation on reduction of lymphocyte DNA damage induced by T-2 toxin and deoxynivalenol in weaned pigs. Anim. Feed Sci. Technol., v.141, p. 274-286, 2008.

FREY, J. C. et al. Comparative studies of microbial populations in the rumen, duodenum, ileum and feces of lactating dairy cows. J. Appl. Microbiol., v. 108, p. 1982-1993, 2010.

FRISVAD, J. C.; ANDERSEN, B.; THRANE, U. The use of secondary metabolite profiling in chemotaxonomy of filamentous fungi. Mycol. Res., v. 112, p. 231-240, 2008. 
FRIZZELL, C. et al. Biotransformation of zearalenone and zearalenols to their major glucuronide metabolites reduces estrogenic activity. Toxicol. in Vitro, v. 29, p. 575$581,2015$.

FURLONG, E. B. et al. Mycotoxins and fungi in wheat harvested during 1990 in test plots in the state of São Paulo, Brazil. Mycopathologia, v. 131, p. 185-190, 1995a.

FURLONG, E. B. et al. Mycotoxins and fungi in wheat stored in elevators in the state of Rio Grande do Sul, Brazil. Food Addit. Contam., v. 12, p.683-688, 1995b.

GARCIA JÚNIOR, D. et al. Relação entre a incidência de Fusarium graminearum em sementes, emergência e ocorrência de giberela em plântulas de trigo. Trop. Plant Pathol., v. 33, p. 302-308, 2008.

GARDINER D. M. et al. Low pH regulates the production of deoxynivalenol by Fusarium graminearum. Microbiology, v. 155, p. 149-3156, 2009.

GONZÁLEZ, H. H. L. et al. (2008). Trichothecenes and mycoflora in wheat harvested in nine locations in Buenos Aires province, Argentina. Mycopathologia, v. 165, p. 105-14, 2008.

GOSWAMI, R. S.; KISTLER, C. H. Pathogenicity and in planta mycotoxin accumulation among members of the Fusarium graminearum species complex on wheat and rice. Phytopathology, v. 95, p. 1397-1404, 2005.

GOUZE, M. E. et al. Effect of subacute oral doses of nivalenol on immune and metabolic defense systems in mice. Vet. Res., v. 38, p. 635-646, 2007.

GOYARTS, T.; DÄNICKE, S. Bioavailability of the Fusarium toxin deoxynivalenol (DON) from naturally contaminated wheat for the pig. Toxicol. Lett. V. 163, p. 171182, 2006.

GUTLEB, A. C.; MORRISON, E.; MURK, A. J. Cytotoxicity assays for mycotoxins produced by Fusarium strains: a review. Environ. Toxicol. Pharmacol., v.11, p. 309-320, 2000.

HEIDTMANN-BEMVENUTI, R. et al. Determinação de deoxinivalenol e zearalenona em arroz natural e parborizado e suas frações utilizando quechers e hplc/uv-fl. Quim. Nova, v. 35, p. 1244-1249, 2012.

HOHN, T. M.; KRISHNA, R.; PROCTOR, R. H. Characterization of a transcriptional activator controlling trichothecene toxin biosynthesis. Fungal Genet. Biol., v. 26, p. 224-235, 1999. 
HOREVAJ, P.; MILUS, E. A., BLUHM, B. H. A real-time qPCR assay to quantify Fusarium graminearum biomass in wheat kernels. J. Appl. Microbiol., v. 111, p. 396-406, 2011.

HORVAT, D. et al. The influence of Fusarium infection on wheat (Triticum aestivum $\mathrm{L}$.) proteins distribution and baking quality. Cereal Res Com., v. 43, p 6171, 2014.

IOOS, R.; BELHADJ, A.; MENEZ, M. Occurrence and distribution of Microdochium nivale and Fusarium species isolated from barley, durum and soft wheat grains in France from 2000 to 2002. Mycopathologia, v. 158, p. 351-362, 2004.

ITO, Y. et al. Effects of nivalenol on pregnancy and fetal development of mice. Mycotoxin Res., v. 2.2, p. 71-77, 2006.

JACOBSEN, L. A. Trigo. Porto Alegre: Série Realidade Rural, 2003, v. 32, 42 p.

JENNINGS, P. et al. Determination of deoxynivalenol and nivalenol chemotypes of Fusarium culmorum isolates from England and Wales by PCR assay. Plant Pathol., v. 53, p. 182-190, 2004.

JIAO, F.; KAWAKAMI, A.; NAKAJIMA, T. Effects of different carbon sources on trichothecene production and Tri gene expression by Fusarium graminearum in liquid culture. FEMS Microbiol. Lett., v. 285, p. 212-219, 2008.

JOINT FAO/WHO EXPERT COMMITTEE ON FOOD ADDITIVES (JECFA). Geneva: World Health Organization, 2000. WHO Food Additives Series n. 44.

KADOTA, T. et al. Comparative study of deoxynivalenol, 3-acetyldeoxynivalenol, and 15-acetyldeoxynivalenol on intestinal transport and IL-8 secretion in the human cell line Caco-2. Toxicol. in Vitro, v. 27, p. 1888-1895, 2013.

KAWAKAMI, A.; NAKAJIMA, T.; HIRAYAE, K. Effects of carbon sources and amines on induction of trichothecene production by Fusarium asiaticum in liquid culture. FEMS Microbiol. Lett., v. 352, p. 204-212, 2014.

KELLER, N. P.; HOHN, T. M. Metabolic pathway gene clusters in filamentous fungi. Fungal Genet. Biol., v. 21, p. 17-29, 1997.

$\mathrm{KIM}, \mathrm{Y}$. et al. Two different polyketide synthase genes are required for synthesis of zearalenone in Gibberella zeae. Mol. Microbiol., v. 58, p. 1102-1113, 2005.

$\mathrm{KLITTICH}, \mathrm{C}$. J. R. et al. Fusarium thapsinum (Gibberella thapsina): A new species in sectin Liseola from sorghum. Mycologia, v. 89, p. 643- 652, 1997. 
KÖHL, J.; DE HAAS, B. H.; KASTELEIN, K.; BURGERS, S. L. G. E.;WAALWIJK, C. Population dynamics of Fusarium spp. and Microdochium nivale in crops and crop residues of winter wheat. Phytopathology, v. 97, p. 971-978, 2007.

KONIGS, M. et al. Metabolism and cytotoxic effects of T-2 toxin and its metabolites on human cells in primary culture. Toxicology, v. 258, p. 106-115, 2009.

KOUADIO, J. H., et al.. Effects of combinations of Fusarium mycotoxins on the inhibition of macromolecular synthesis, malondialdehyde levels, DNA methylation and fragmentation, and viability in Caco-2 cells. Toxicon., v. 49, p. 306-317, 2007.

KUIPER, G. J. et al. Interaction of estrogenic chemicals and phytoestrogens with estrogen receptor beta. Endocrinology, v. 139, p. 4252-4263, 1998.

LACEY, J.; BATEMAN, G. L.; MIROCHA, C. J. Effects of infection time and moisture on development of ear blight and deoxynivalenol production by Fusarium spp. in wheat. Ann. Appl. Biol., v. 134, p. 277-283, 1999.

LEE, T, et al. Identification of deoxynivalenol-and nivalenol-producing chemotypes of Gibberella zeae by using PCR. Appl. Environ. Microbiol., v. 67, p. 2966-2972, 2001.

LESLIE, J. F.; SUMMERELL, B. A. The Fusarium laboratory manual. lowa: Blackwell Scientific Publishing, 2006, 388 p.

LIOI, M. B. et al. Ochratoxin and zearalenone: a comparative study on genotoxic effects and cell death induced in bovine lymphocytes. Mutat. Res., v. 557, p. 19-24, 2004.

MALEKINEJAD, H.; MAAS-BAKKER, R.; FINK-GREMMELS, J. Species differences in the hepatic biotransformation of zearalenone. The Vet. J., v. 172, p. 96-102, 2006.

MARESCA, M. From the Gut to the Brain: Journey and Pathophysiological Effects of the Food-Associated Trichothecene Mycotoxin Deoxynivalenol. Toxins, vol. 5, p. 784-820, 2013.

MASSART, F. V. et al. High growth rate of girls with precocious puberty exposed to estrogenic mycotoxins J. Pediatr., v. 152, p. 690-695, 2008.

MCCORMICK, S. P. et al. Trichothecenes: from simple to complex mycotoxins. Toxins, v. 3, p. 802-814, 2011.

MERHEJ J. et al. Acidic $\mathrm{pH}$ as a determinant of TRI gene expression and trichothecene B biosynthesis in Fusarium graminearum. Food Addit. Contam. Part A, v. 27, p. 710-717, 2010. 
MERHEJ, J. M. et al. The velvet gene, FgVe1, affects fungal development and positively regulates trichothecene biosynthesis and pathogenicity in Fusarium graminearum. Mol. Plant Pathol., v. 13, p. 363-374, 2012.

MERHEJ, J.; FORGET F.; BARREAU C. Regulation of trichothecene biosynthesis in Fusarium: recent advances and new insights. Appl. Microbiol. Biotech., v. 91, p. 519-528, 2011.

MILES, C. O. et al. Ovine metabolism of zearalenone to a-zearalanol (zeranol). J. Agricul. Food Chem., v. 44, p. 3244-3250, 1996.

Ministério da Agricultura, Pecuária e Abastecimento (MAPA). 2010. Instrução normativa MAPA 38/2010. Disponível em: <http://www.agricultura.gov.br/vegetal/sanidade-vegetal/legislacao>. Acesso em: 20 mar. 2015.

MYUNG K. et al. FvVE1 regulates biosynthesis of the mycotoxins fumonisins and fusarins in Fusarium verticillioides. J. Agric. Food Chem., v. 57, p. 5089-5094, 2009.

NAGASHIMA, $\mathrm{H}$. et al. Comparison of antiproliferative effects of trichothecene mycotoxins, nivalenol and deoxynivalenol, in cultured cells. Rep. Natl. Food Res. Inst., v. 76, p. 29-32, 2012.

NAGASHIMA, H. et al. Cytotoxic effects of nivalenol on HL60 cells. Mycotoxins, v. 56, p. 65-70, 2006.

NELSON, P. E. History of Fusarium Systematics. Am. Phytopathol. Soc., v.81, p. 1045-1048, 1991.

NELSON, P. E.; DIGNANI, M. C.; ANAISSIE, E. J. Taxonomy, biology and clinical aspects of Fusarium species. Clin. Microbiol. Rev., v.7, p.479-504, 1994.

NICHOLSON, P. et al. Development of a PCR assay to identify and quantify Microdochium nivale var. nivale and Microdochium nivale var.majus in wheat. Physiol. Mol. Plant. Pathol., v. 48, p.257-271, 1996.

NICO, B.; RIBATTI, D. Morphofunctional aspects of the blood-brain barrier. Curr. Drug Metab., v. 13, p. 50-60, 2012.

NICOLAISEN, M., Real-time PCR for quantification of eleven individual Fusarium species in cereals. J. Microbiol. Methods, v. 76, p. 234-240, 2009.

NIELSEN, L. K. et al. TRI12 based quantitative real-time PCR assays reveal the distribution of trichothecene genotypes of $F$. graminearum and $F$. culmorum isolates in Danish small grain cereals. Int. J. Food Microbiol., v. 157, p. 384-392, 2012. 
O'DONNELL, K. et al. Genealogical concordance between the mating type locus and seven other nuclear genes supports formal recognition of nine phylogenetic distinct species within the Fusarium graminearum clade. Fungal Genet. Biol., v. 41, p. 600623, 2004.

O'DONNELL, K.; CIGELNIK, E. Two divergent intragenomic rDNA ITS2 types within a monophyletic lineage of the fungus Fusarium are non-orthologous. Mol. Phylogenet. Evol., v.7, p. 103-116, 1997.

PAN, D.; GRANERI, J.; BETTUCCI, L. Correlation of rainfall and levels of deoxynivalenol in wheat from Uruguay, 1997-2003. Food Addit. Contam., Part B. v. 2, n. 2, p. 162-165, 2009.

PANISSON, E.; REIS, E. M.; BOLLER, W . Quantificação de danos causados pela Giberela em cereais de inverno, na safra 2000, em Passo Fundo, RS. Fitopatol. Bras., v. 28, p. 189-192, 2003.

PARRY, D. W.; JENKINSON, P.; MCLEOD, L. Fusarium ear blight (scab) in small grain cereals-a review. Plant. Pathol., v. 44, p. 207-238, 1995.

PARVEEN, M.; ZHU, Y.; KIYAMA, R Expression profiling of the genes responding to zearalenone and its analogues using estrogen-responsive genes. FEBS Lett., $v$. 583, p. 2377-2384, 2009.

PATRIARCA, A. et al. Mycotoxin production by Alternaria strains isolated from Argentinean wheat. Int. J. Food Microbiol., v.119, p. 219-222, 2007.

PEPLOW, A. W. et al. Identification of new genes positively regulated by Tri10 and a regulatory network for trichothecene mycotoxin production. Appl. Environ. Microbial., v. 69, p. 2731-2736, 2003.

PERAICA, M.; RADIC, B.; PAVLOVIC, M. Toxic effects of mycotoxins in humans. Bull. World Health Organ., v. 77, p. 754-766, 1999.

PESTKA, J. J. et al. Cellular and molecular mechanisms for immune modulation by deoxynivalenol and other trichothecenes: unraveling a paradox. Toxicol Lett., v. 153, p. 61-73, 2004.

PESTKA, J. J.; ISLAM, Z.; AMUZIE, C. J. Immunochemical assessment of deoxynivalenol tissue distribution following oral exposure in the mouse. Toxicol. Lett., v. 178, p. 83-87, 2008.

PESTKA, J. J.; SMOLINSKI, A. T. Deoxynivalenol: toxicology and potential effects on humans. J. Toxicol. Health B. Crit. Rev., v.8, p. 39-69, 2005. 
PFAFFL, M. W. A new mathematical model for relative quantification in real time RTPCR. Nucl. Acids Res. v. 29, p. 2002-2007, 2001.

PILLAY, D. et al. The quantitative analysis of zearalenone and its derivatives in plasma of patients with breast and cervical cancer. Clin. Chem. Lab. Med., v. 40, p. 946-951, 2002.

PINTO, V. E., et al. Natural occurrence of nivalenol and mycotoxigenic potential of Fusarium graminearum strains in wheat affected by head blight in Argentina. Braz. Microbiol., v.39, p. 157-162, 2008.

POZZI, C. R. et al. Postharvest and stored corn in Brazil: mycoflora interaction, abiotic factors and mycotoxin occurrence. Food Addit. Contam. Part A. v. 12, p. 313-319, 1995.

PRELUSKY, D. B. et al. Nontransmission of deoxynivalenol (vomitoxin) to milk following oral administration to dairy cows. J. Environ. Sci. Health B., v. 19, p. 593609, 1984.

PRELUSKY, D. B.; HARTIN, K. E.; TRENHOLM, H. L. Distribution of deoxynivalenol in cerebral spinal fluid following administration to swine and sheep. J. Environ. Sci. Health B., v. 25, p. 395-413, 1990.

PROCTOR, R. H. et al. Tri6 encodes an unusual zinc finger protein involved in regulation of trichothecene biosynthesis in Fusarium sporotrichioides. Appl. Environ. Microbiol., v. 61, p. 1923-1930, 1995.

PURI, K. D.; ZHONG, S. The 3ADON population of Fusarium graminearum found in North Dakota is more aggressive and produces a higher level of DON than the prevalent 15ADON population in spring wheat. Phytopathology, v. 100, p. 10071014, 2010.

QUARTA, A. et al. Multiplex PCR assay for the identification of nivalenol, 3-and 15acetyl-deoxynivalenol chemotypes in Fusarium. FEMS Microbiol. Lett., v. 259, p. 713, 2006.

RAHMAN, S. Handbook of food preservation. 2nd ed, Boca Raton: CRC Press, 2007, $1088 \mathrm{p}$.

REYNOSO, M. M. et al. Trichothecene genotypes and chemotypes in Fusarium graminearum strains isolated from wheat in Argentina. Int. J. Food Microbiol., v. 145, p. 444-448, 2012.

RIDDELL, R. W. Permanent Stained Mycological Preparations Obtained by Slide Culture. Mycol. Soc. Am., v. 42, p. 265-270, 1950. 
ROIGÉ, M.B. et al. Mycobiota and mycotoxins in fermented feed, wheat grains and corn grains in Southeastern Buenos Aires Province, Argentina. Rev. Iberoamericana Micol., v. 26, p. 233-237, 2009.

RONNE, H. Glucose repression in fungi. Trends Genet., v. 11, p. 12-17, 1995.

ROSSI, V. et al. Influence of temperature and humidity on the infection of wheat spikes by some fungi causing Fusarium head blight. J. Plant Pathol., v. 83, p. 189198, 2001.

SABINO, M. et al. Determinação de deoxinivalenol em trigo e milho em gräo por cromatografia em camada delgada. Rev. Inst. Adolfo Lutz, v. 49, 155-159, 1989.

SAMPIETRO, D. A. et al. Trichothecene genotypes and chemotypes in Fusarium graminearum complex strains isolated from maize fields of northwest Argentina. Int. J. Food Microbiol., v. 153, p. 229-233, 2012.

SANTOS, J. S. et al. Natural occurrence of deoxynivalenol in wheat from Paraná State, Brazil and estimated daily intake by wheat products. Food Chem., v. 138, p. 90-95, 2013.

SCHMALE, D. G. et al. Trichothecene genotypes of Gibberella zeae from winter wheat fields in the eastern USA. Plant Pathol. v. 60, p. 909-917, 2011.

SCHMITTGEN, T. D.; LIVAK, K. J. Analyzing real-time PCR data by the comparative Ct method. Nature Prot., v. 3, p. 1101-1108, 2008.

SCOZ, L. B. et al. Trichothecene mycotoxin genotypes of Fusarium graminearum sensu stricto and Fusarium meridionale in wheat from southern Brazil. Plant Pathol., v. 58, p. 344-351, 2009.

SEUS, E. R. Otimização de método para a determinação de tricotecenos em amostras de trigo. 2014. 122 f. Disertação (Mestrado em Química Tecnológica e Ambiental). Universidade Federal do Rio Grande, Rio Grande, RS, 2014.

SIUDA, R. et al. Influence of the degree of fusariosis on technological traits of wheat grain. Int. J. Food Sci. Technol., v. 45, p. 2596-2604, 2010.

SMITH, T. K.; McMILLAN, G.; CASTILLO., J. B. Effect of feeding blends of Fusarium mycotoxin-contaminated grains containing deoxynivalenol and fusaric acid on growth and feed consumption of immature swine. J. Anim Sci., v. 75, p. 2184-2191, 1997.

SMITH, W. G. Diseases of Field and Garden Crops, London, 1884, p. 208-213 apud CHAMPEIL, A.; DORÉ, T.; FOURBET, J. F. Fusarium head blight: epidemiological origin of the effects of cultural practices on head blight attacks and 
the production of mycotoxins by Fusarium in wheat grains, Plant Sci., v. 166, p. 1389-1415, 2004.

SØRENSEN, J. L.; GIESE, H. Influence of carbohydrates on secondary metabolism in Fusarium avenaceum. Toxins, v. 5.9, p. 1655-1663, 2013.

SPOLTI, P. et al. Phenotypic and pathogenic traits of two species of the Fusarium graminearum complex possessing either 15-ADON or NIV genotype. Eur. J. Plant Pathol,, v. 133, p. 621-629, 2012.

STĘPIEŃ, Ł. et al. "Wheat-infecting Fusarium species in Poland-their chemotypes and frequencies revealed by PCR assay. J. Appl. Genet., v. 49, p. 433-441, 2008.

STRANGE, R. N.; SMITH, H. A fungal growth stimulant in anthers which predisposes wheat to attack by Fusarium graminearum. Physiol. Plant Pathol., v. 1, p. 141$150,1971$.

TAG, A. G., et al. A novel regulatory gene, Tri10, controls trichothecene toxin production and gene expression. Appl. Environ. Microbial., v. 67, p. 5294-5302, 2001.

TAJIMA, O., et al. Statistically designed experiments in tiered approach to screen mixtures of Fusarium mycotoxins for possible interactions. Food Chem. Toxicol., v. 40, p. 685-695, 2002.

TAKAHASHI, M. et al. A 90-day subchronic toxicity study of nivalenol, a trichothecene mycotoxin, in F344 rats. Food Chem. Toxicol., v. 46, p. 125-135, 2008.

TIEMANN, U., et al. Effects of diets with cereal grains contaminated by graded levels of two toxins on selected immunological and histological measurements in the spleen of gilts. J. Anim. Sci., v. 84, p. 236-245, 2006.

TOMASZEWSKI, J. et al. Zearalenone concentration in normal, hyperplastic and neoplastic human endometrium tissue. Ginekol. Pol., v. 69, p. 363-366, 1998.

TÓTH, B. et al. Common resistance of wheat to members of the Fusarium graminearum species complex and F. culmorum. Plant Breeding, v. 127, p. 1-8, 2008.

TROSMO, A. M.; HSIANG, T.; OKUYAMA, H.; AND NAKAJIMA, T. 2001. Low temperature diseases caused by Microdochium nivale. In Low temperature plant microbe interactions under snow. Japan: Hokkaiko National Agricultural Experiment Station, 2001, 75- 86. 
UENO, Y. Trichothecenes- Chemical, Biological and Toxicological Aspects. Kodansha/Elsevier, Tokyo/Amsterdam, 1983, 328 p.

UNITED STATES DEPARTMENT OF AGRICULTURE (USDA) 2011. Global Agricultural Information Network. Disponível em: http://gain.fas.usda.gov/Recent\%20GAIN\%20Publications/Maximum\%20Levels\%20 of\%20Mycotoxins\%20in\%20Foods_Beijing_China\%2020Peoples\%20Republic\%20of_12-29-2014.pdf> Acesso em: 18 fev. 2015.

VARGA, E. et al. New tricks of an old enemy: Isolates of Fusarium graminearum produce a type A trichothecene mycotoxin. Environ. Microbiol. (2014). doi: $10.1111 / 1462-2920.12718$

VIDEMANN, B. et al. Metabolism and transfer of the mycotoxin zearalenone in human intestinal Caco-2 cells. Food Chem. Toxicol., v. 46, p. 3279-3286, 2008.

WALTER, J.; LEY, R. The human gut microbiome: Ecology and recent evolutionary changes. Annu. Rev. Microbiol., v. 65, p. 411- 429, 2011.

WARD, T. J. An adaptive evolutionary shift in Fusarium head blight pathogen populations is driving the rapid spread of more toxigenic Fusarium graminearum in North America. Fungal Genet. Biol., v. 45, p. 473- 484, 2008.

WARD, T. J. et al. Ancestral polymorphism and adaptive evolution in the trichothecene mycotoxin gene cluster of phytopathogenic Fusarium. Proc. Natl. Acad. Sci., v. 99, p. 9278- 9283, 2002.

WHITE T.J. et al. Amplification and direct sequencing of fungal ribosomal RNA genes for phylogenetics. In PCR Protocols: A Guide to Methods and Applications. New York: Academic Press, 1990, p. 315-322.

WITHANAGE, G. M.; KOYAMA, H.; ISHIWATA, I. Agonistic and antagonistic effects of zearalenone, an etrogenic mycotoxin, on SKN, HHUA, and HepG2 human cancer cell lines. Vet. Hum. Toxicol., v. 43, p. 6-10, 2001.

$\mathrm{WU}, \mathrm{X}$. et al. Synthesis and characterization of deoxynivalenol glucuronide: Its comparative immunotoxicity with deoxynivalenol. Food Chem. Toxicol.. v. 45, p. 1846-1855, 2007.

YANG, J. Y. Toxic effects of T-2 toxin on reproductive system in male mice. Toxicol. Ind. Health, v. 26, p. 25-31, 2010.

ZAIN, M. E. Biochemical Markers in Taxonomy of the Genus Fusarium. Res. J. Agri. Biol. Sci., v. 6, p. 1-7, 2010. 
ZHANG J. B. et al. Determination of the trichothecene mycotoxin chemotypes and associated geographical distribution and phylogenetic species of the Fusarium graminearum clade from China. Mycol. Res., v. 111, p. 967-75, 2007.

ZINEDINE, A. et al. Review on the toxicity, occurrence, metabolism, detoxification, regulations and intake of zearalenone: An oestrogenic mycotoxin. Food Chem. Toxicol., v.45, p.1-18, 2007. 


\section{APÊNDICES}

Apêndice A - Curvas padrão referentes a eficiência dos iniciadores utilizados para análise de expressão gênica de tricotecenos

Gene TRI 4

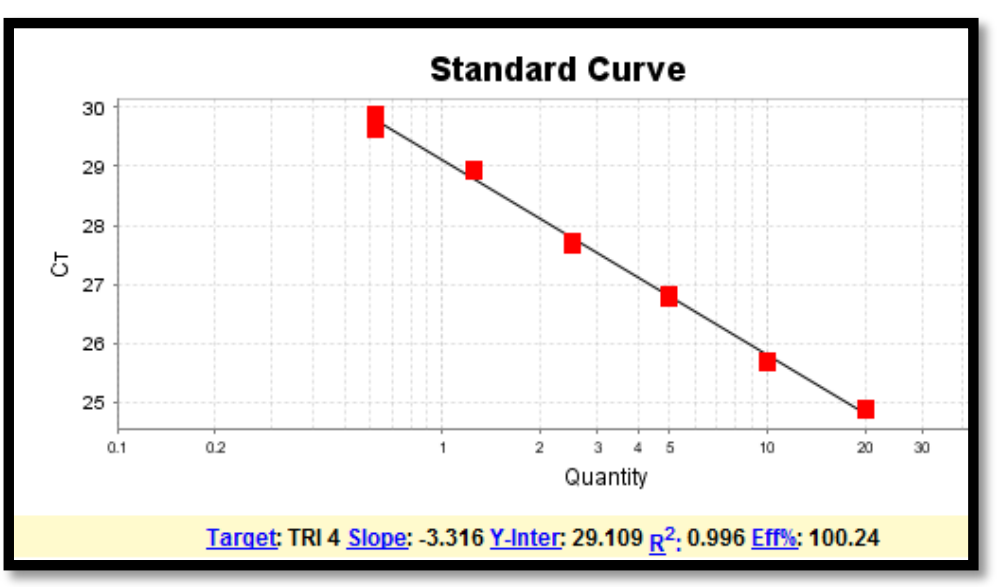

Gene TRI 5

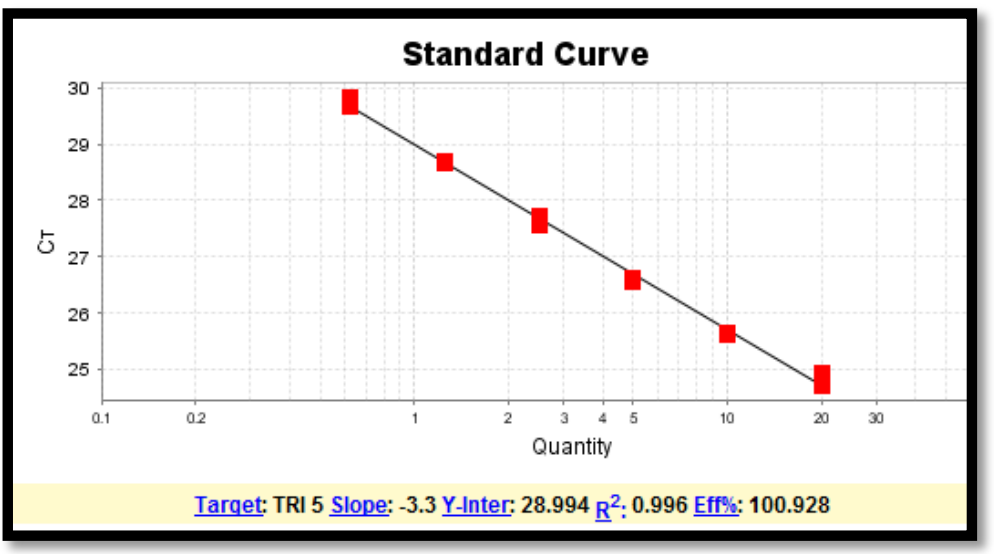


Gene TRI 6

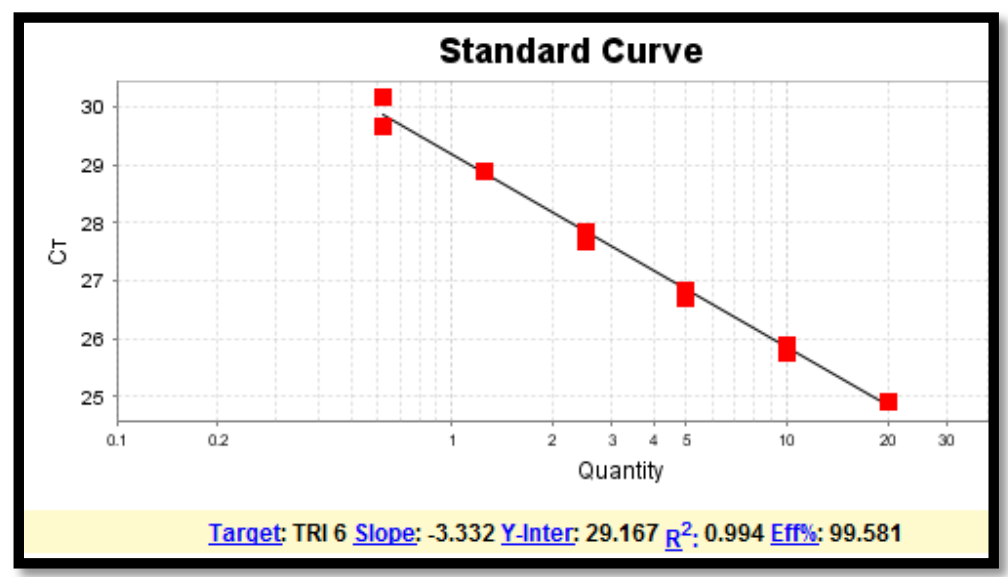

Gene TRI 12

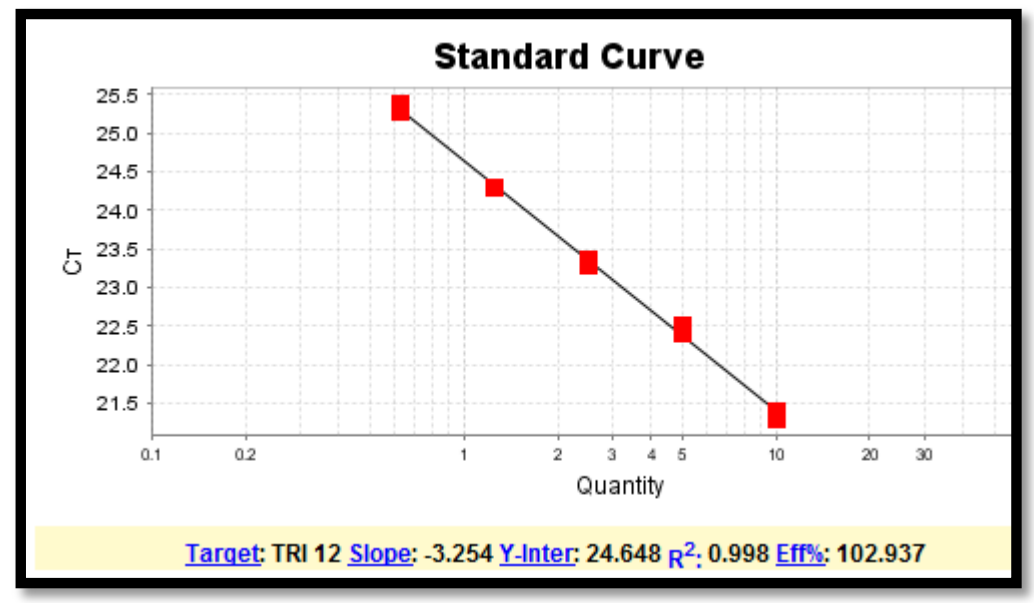

Gene EF-1 $\alpha$

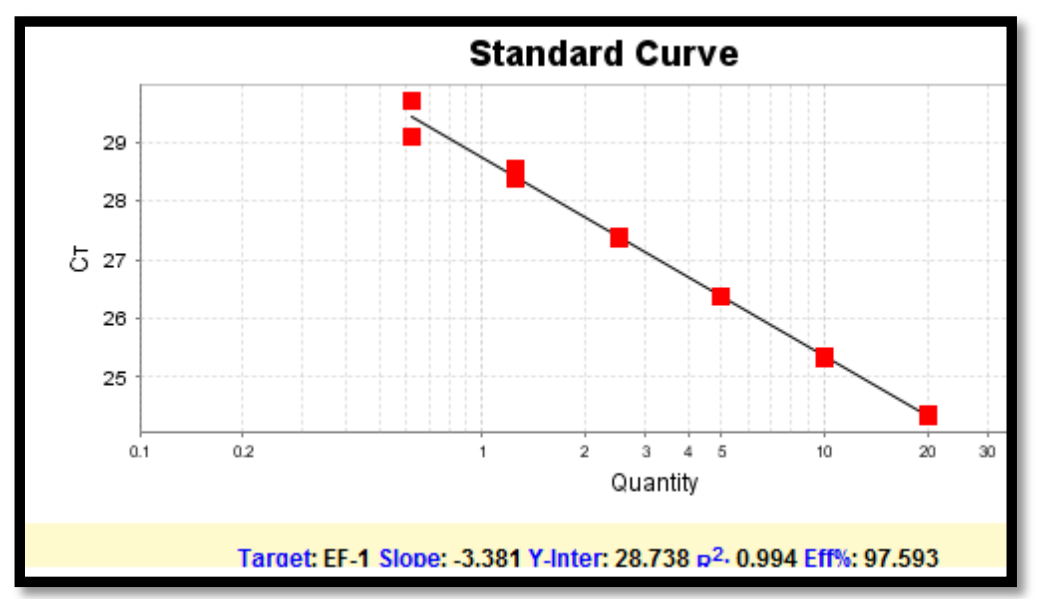


Apêndice B - Curva de melting indicando a especificidade dos iniciadores utilizados na técnica de expressão gênica de tricotecenos.

Gene TRI 4

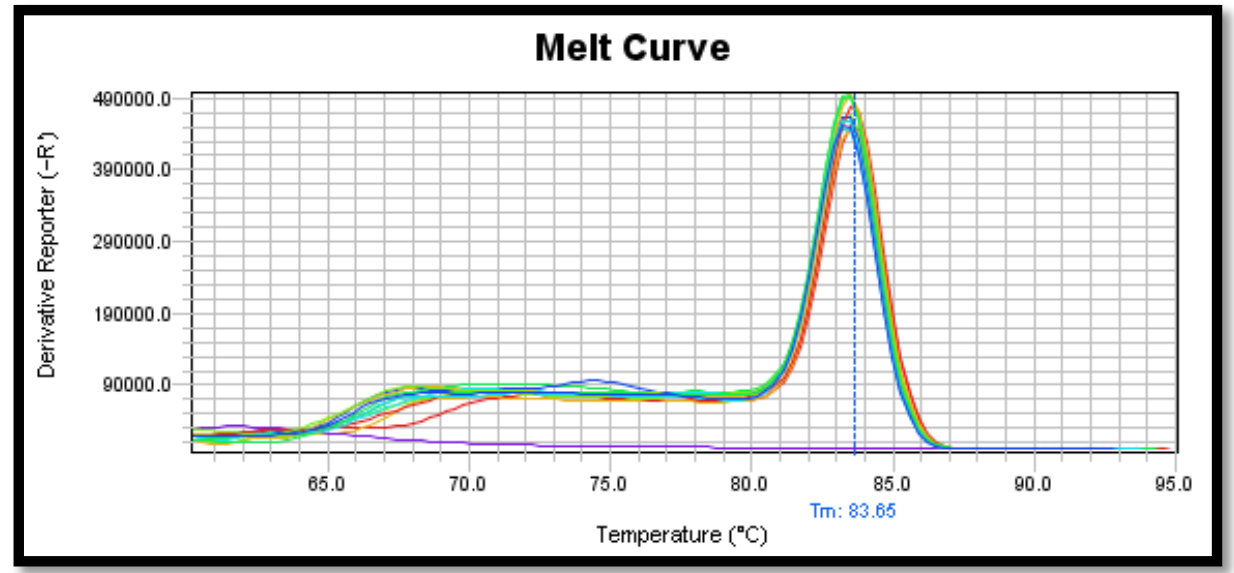

Gene TRI 5

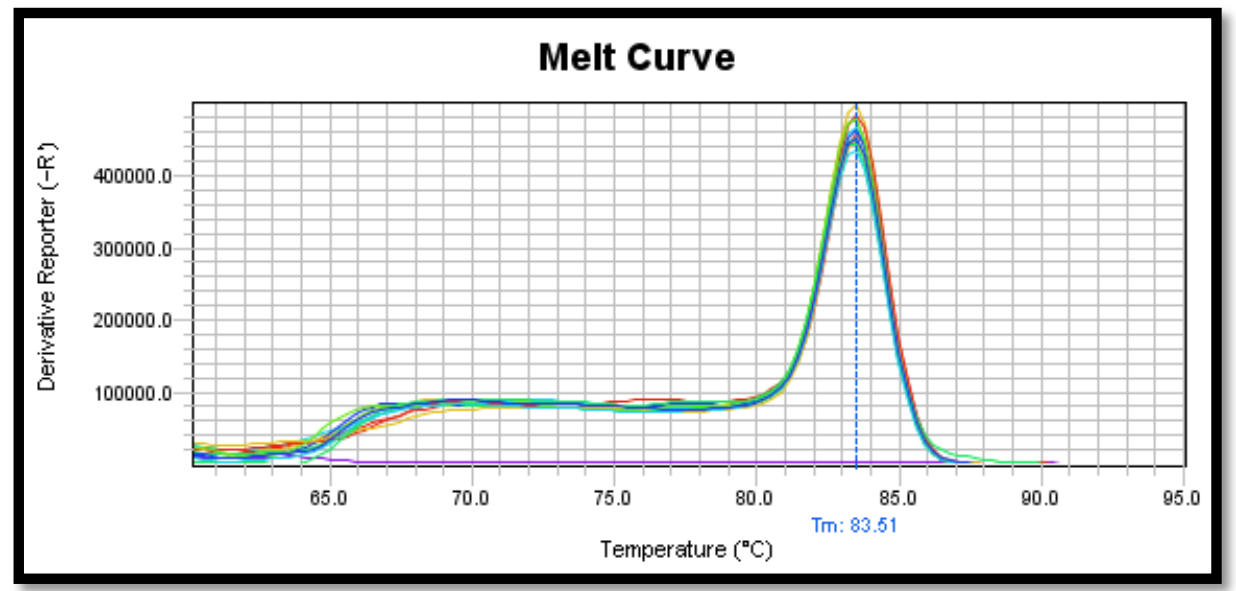

Gene TRI 6

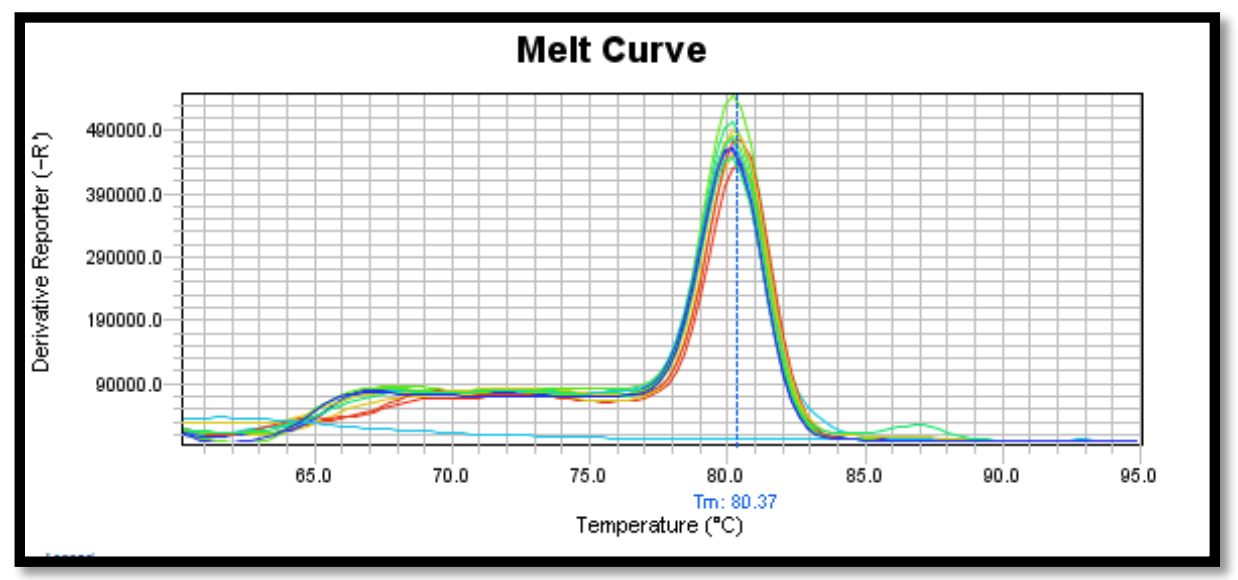


Gene TRI 12

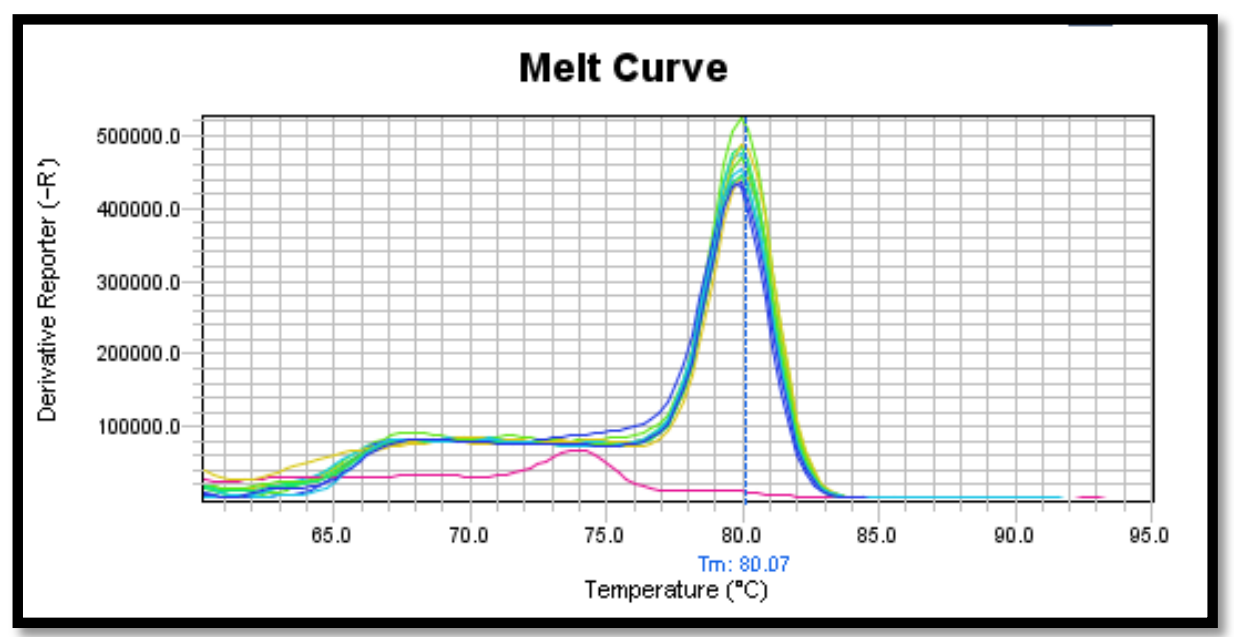

Gene EF-1a

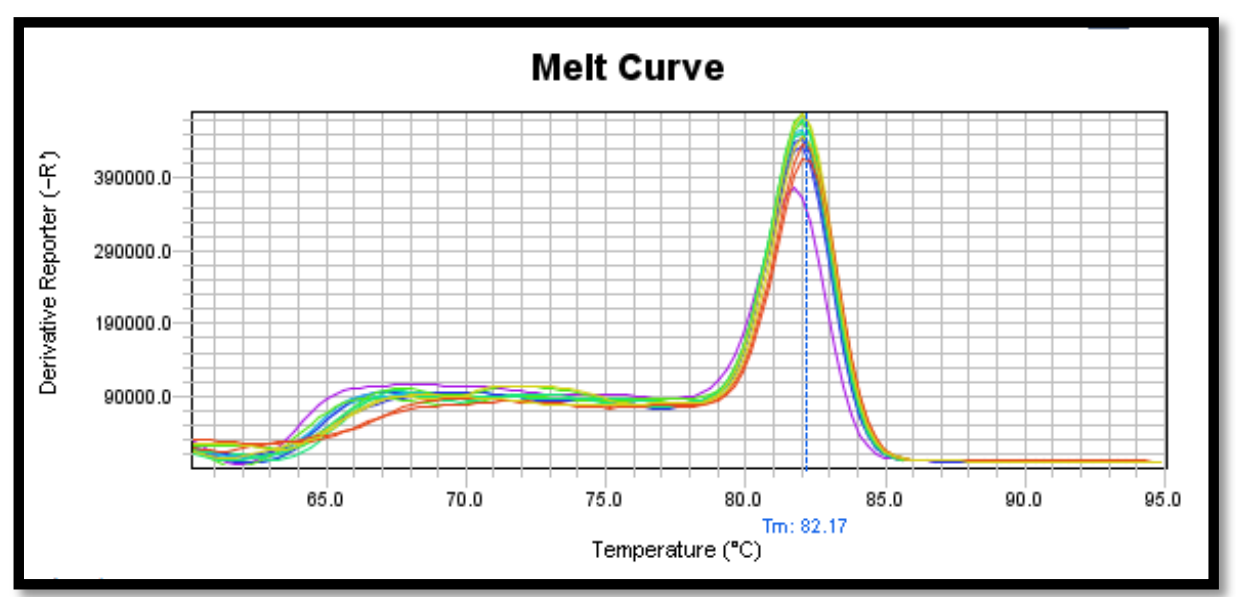


Apêndice C - Curvas padrão para quantificação de DNA dos genótipos nos grãos de trigo

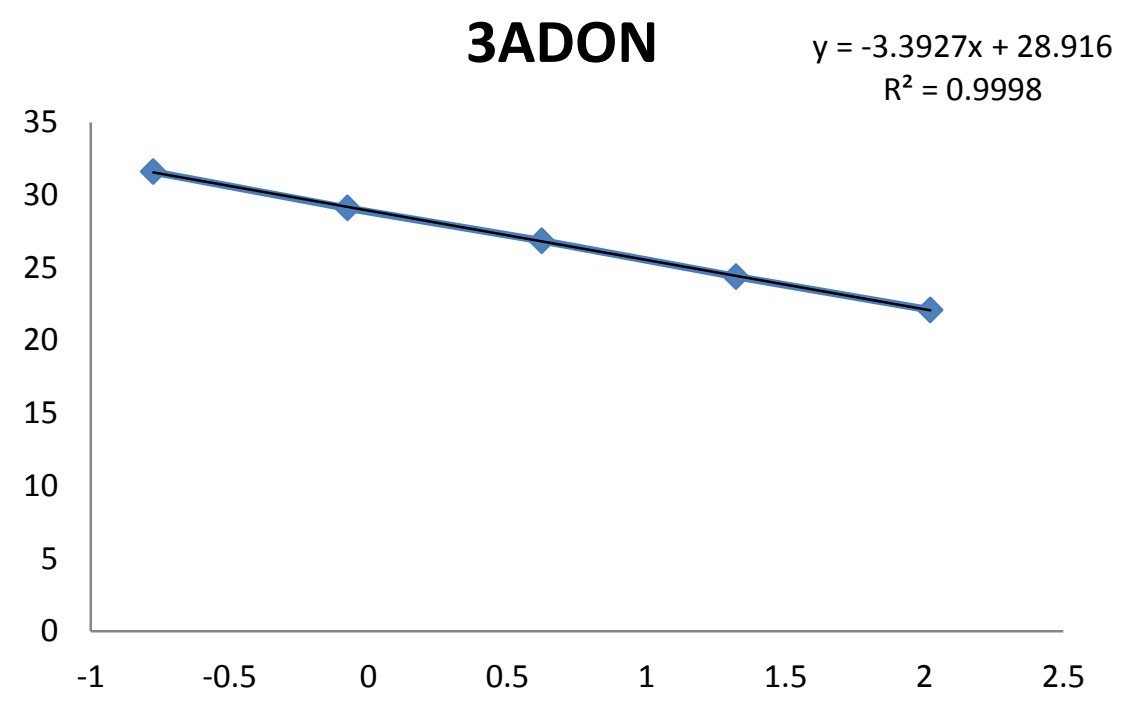

15ADON

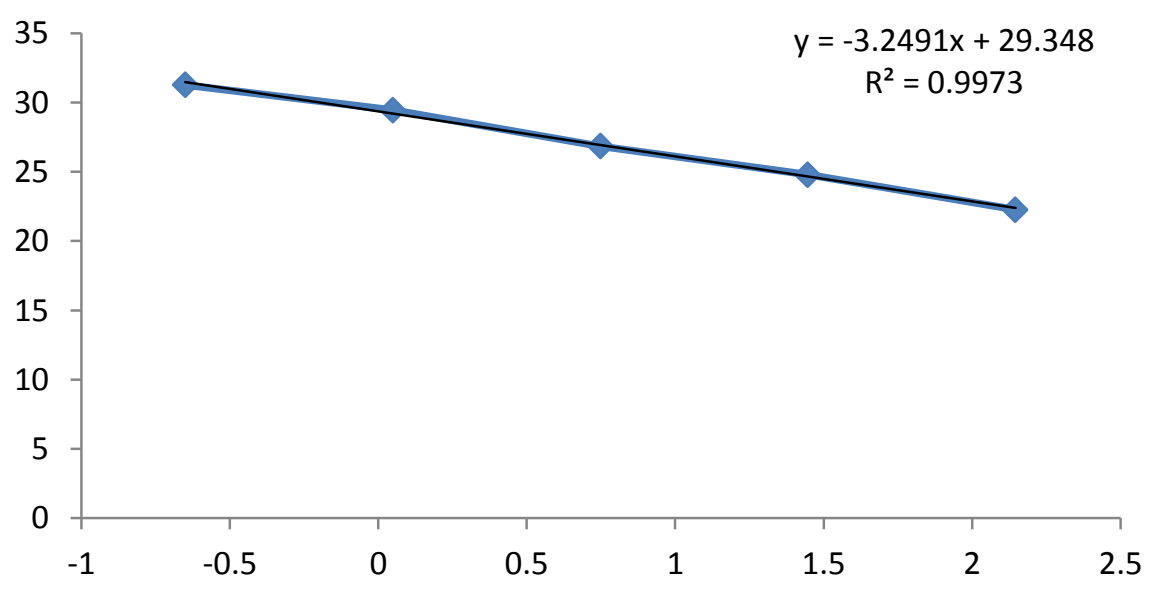




\section{NIV}

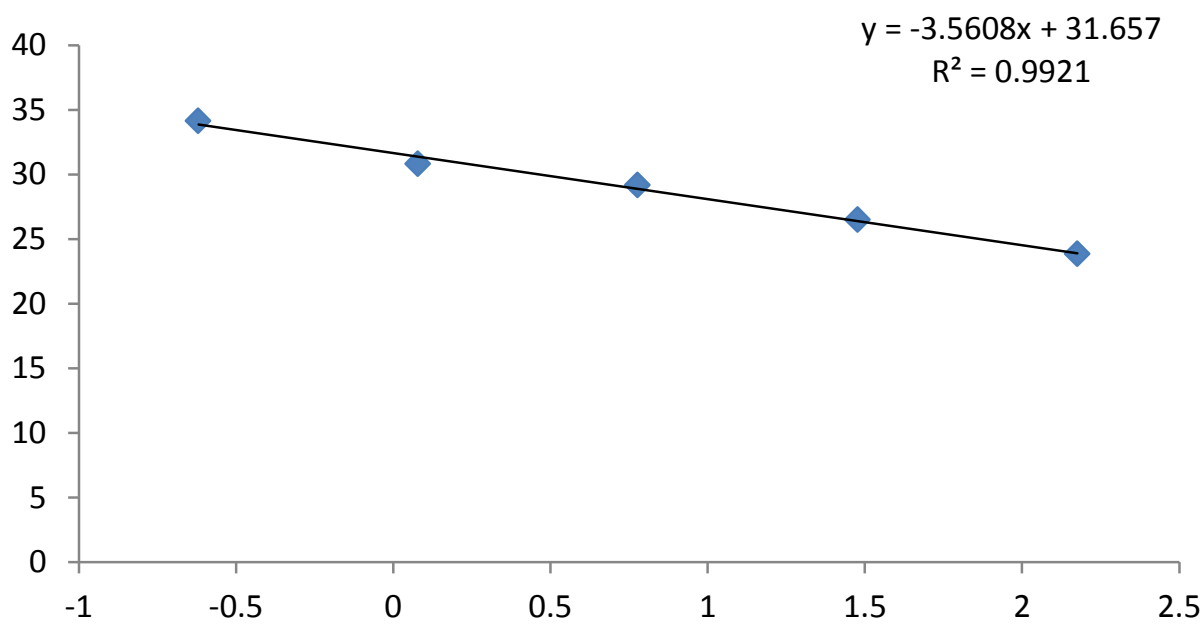

HOR

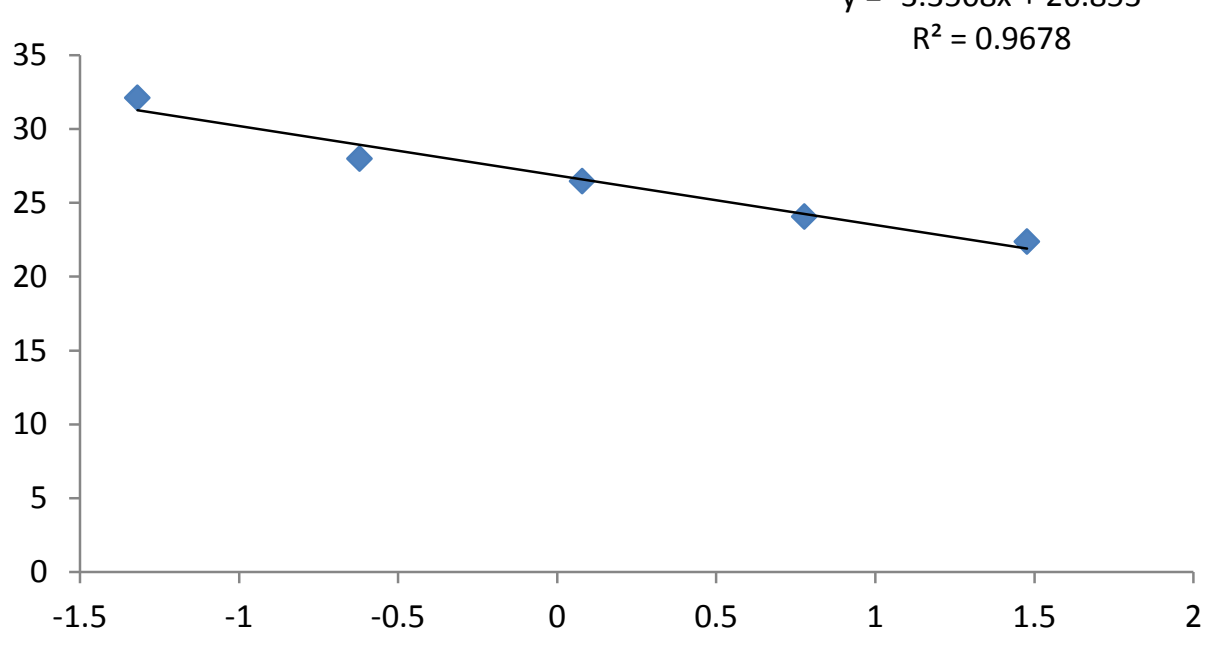


Apêndice D - Equações das curvas analíticas dos padrões de micotoxinas e suas linearidades.

\begin{tabular}{cccccc}
\hline Micotoxina & Detector & $\begin{array}{c}\text { Faixa de } \\
\text { concentraçã } \\
0(\mu \mathrm{g} / \mathrm{mL})\end{array}$ & Curva analítica & $\begin{array}{c}\text { Tempo } \\
\text { de } \\
\text { retenção } \\
\text { (min) }\end{array}$ & $r$ \\
DON & UV & $1-10$ & $y=24071,33 x-465,06$ & 4,9 & 0,9903 \\
ZEA & FL & $0,2-2$ & $y=46778,41 x-498,54$ & 9,8 & 0,9977 \\
\hline
\end{tabular}

UV=ultravioleta; FL=fluorescência; $r$ = coeficiente de correlação. 
Apêndice E - Cromatograma dos padrões de micotoxinas no detector A (ZEA) e B (DON).
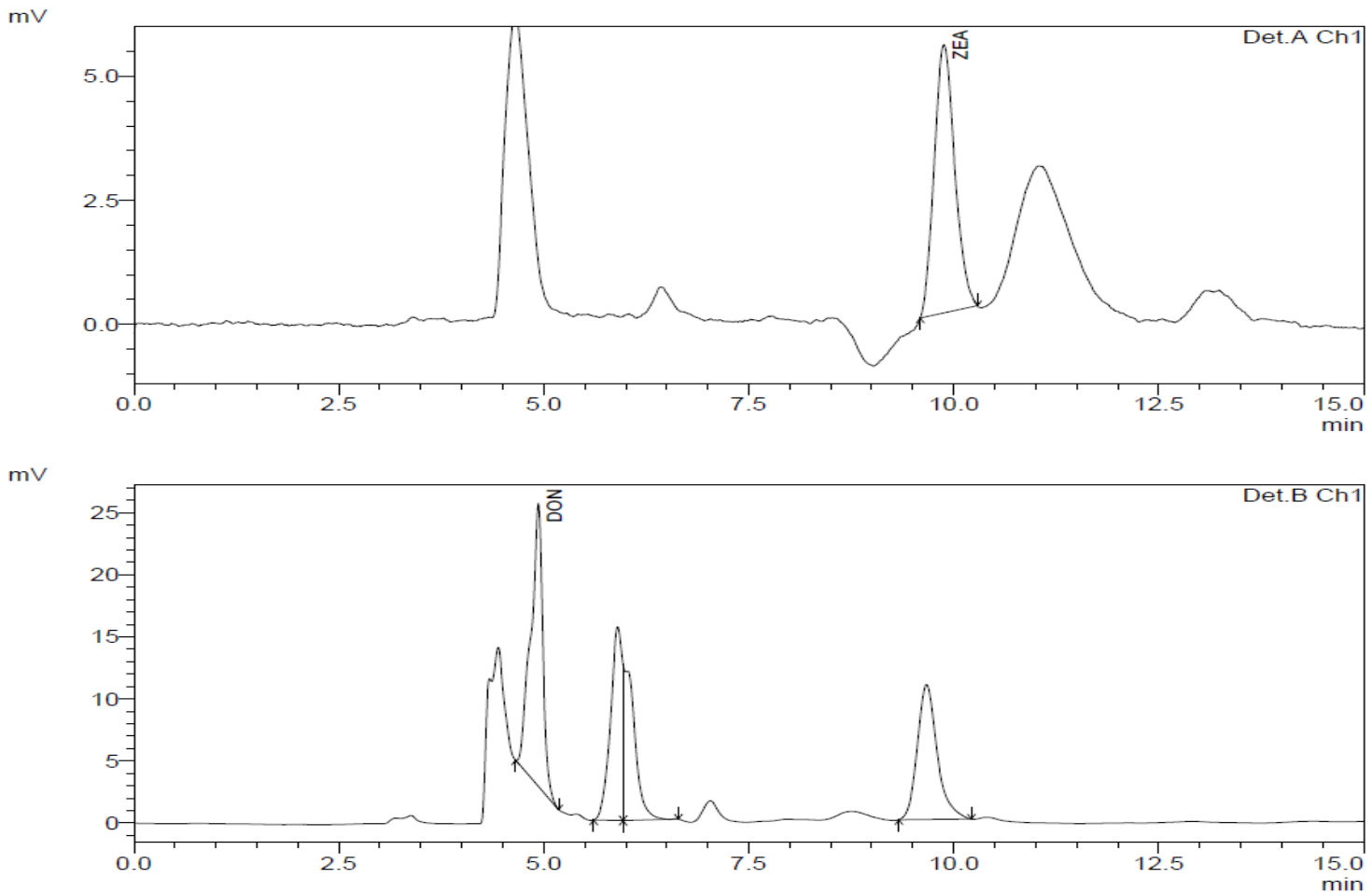